\title{
ALSTOM
}

\section{Demonstration of Mer-Cure ${ }^{\mathrm{TM}}$ Technology for Enhanced Mercury Control}

FINAL REPORT

\section{Reporting Period: March 6, 2007 - June 1, 2008}

Submitted By

Alstom Power Inc.

2000 Day Hill Road

Windsor, Connecticut 06095

Shin Kang

Robert Schrecengost

Prepared For

NETL AAD Document Control Bldg. 921

US Department of Energy

National Energy Technology Laboratory

P.O. Box 10940

Pittsburgh, Pennsylvania 15236-0940

(DOE Cooperative Agreement DE-FC26-07NT42776)

Final Report Submittal Date: December 1, 2008 


\section{Disclaimer}

This report was prepared as an account of work sponsored by an agency of the United States Government. Neither the United States Government nor any agency thereof, nor any of their employees, makes any warranty, express or implied, or assumes any legal liability or responsibility for the accuracy, completeness, or usefulness of any information, apparatus, product, or process disclosed, or represent that its use would not infringe privately owned rights. Reference herein to any specific commercial product, process, or service by trade name, trademark, manufacturer, or otherwise does not necessarily constitute or imply its endorsement, recommendation, or favoring by the United States Government or any agency thereof. The views and opinions of authors expressed herein do not necessarily state or reflect those of the United States Government or any agency thereof. 


\section{Acknowledgements}

Any work of this scope requires the effort and cooperation of many individuals and groups. First of all, Alstom would like to thank the USDOE National Energy Technology Laboratory for their support of this work. The organizations providing co-funding for this program include:

- Lower Colorado River Authority

- Envergex, LLC

- University of North Dakota Energy and Environmental Research Center

- Alstom Power Inc.

The support of Alstom management was invaluable in getting resources necessary to complete the projects. Key contributors include John Marion, Vice President of Alstom Boiler Technology; Dave O’Neill, General Manager for Alstom EBR - Windsor, and Kevin Taugher, R\&D and Technology Director for Alstom EBR.

Key contributions to the project management and accomplishments were made by Dr Shin G. Kang, Prinicipal Investigator and Program Manager for this work. Key members of the project team who supported field testing at the various host sites include:

Lower Colorado River Authority

- Mark Johnson

- Gerald Pargac

- Jane Luedecke

- Randy Gardiner

Mineral Resource Technologies Inc.

- Mike Silvertooth

- Jim Hicks

Alstom Power, Inc.

- Carl Edberg

- Ray Cournoyer

- Stanley Bohdanowicz

- Ken Petersen

- Kurt Johnson

UND-EERC

- Steve Benson

- Richard Schulz

- Don McCollor

- Mike Wuitshick 


\section{Public Abstract}

Alstom Power Inc. has completed a DOE/NETL-sponsored program (under DOE Cooperative Agreement No. DE-FC26-07NT42776) to demonstrate Mer-Cure ${ }^{\mathrm{TM}}$, one of Alstom's mercury control technologies for coal-fired boilers. The Mer-Cure ${ }^{\mathrm{TM}}$ system utilizes a small amount of Mer-Clean ${ }^{\mathrm{TM}}$ sorbent that is injected into the flue gas stream for oxidation and adsorption of gaseous mercury. Mer-Clean ${ }^{\mathrm{TM}}$ sorbents are carbon-based and prepared with chemical additives that promote oxidation and capture of mercury. The Mer-Cure ${ }^{\mathrm{TM}}$ system is unique in that the sorbent is injected into an environment where the mercury capture kinetics is accelerated.

The full-scale demonstration program originally included test campaigns at two host sites: LCRA's 480-MWe Fayette Unit \#3 and Reliant Energy's 190-MW $\mathrm{MW}_{\mathrm{e}}$ Shawville Unit \#3. The only demonstration tests actually done were the short-term tests at LCRA due to budget constraints. This report gives a summary of the demonstration testing at Fayette Unit \#3.

The goals for this Mercury Round 3 program, established by DOE/NETL under the original solicitation, were to reduce the uncontrolled mercury emissions by $90 \%$ at a cost significantly less than $50 \%$ of the previous target of $\$ 60,000 / \mathrm{lb}$ mercury removed.

The results indicated that Mer-Cure ${ }^{T M}$ technology could achieve mercury removal of $90 \%$ based on uncontrolled stack emissions. The estimated costs for $90 \%$ mercury control, at a sorbent cost of $\$ 0.75$ to $\$ 2.00 / \mathrm{lb}$ respectively, were $\$ 13,400$ to $\$ 18,700 / \mathrm{lb} \mathrm{Hg}$ removed.

In summary, the results from demonstration testing show that the goals established by DOE/NETL were met during this test program. The goal of 90\% mercury reduction was achieved. Estimated mercury removal costs were $69-78 \%$ lower than the benchmark of $\$ 60,000 /$ lb mercury removed, significantly less than $50 \%$ of the baseline removal cost. 


\section{Table of Contents}

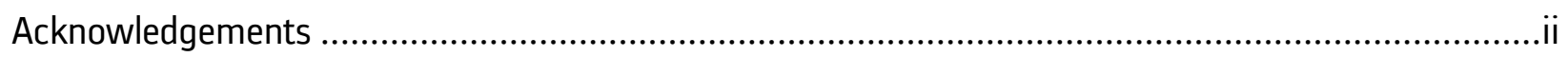

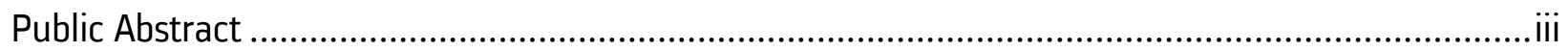

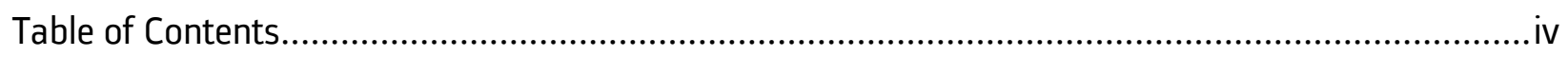

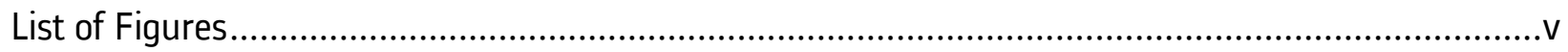

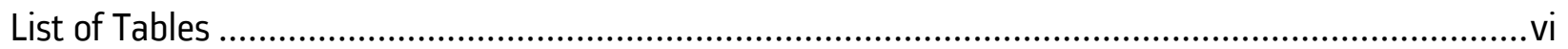

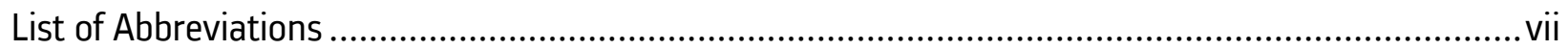

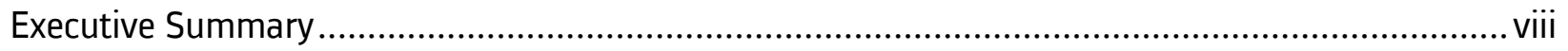

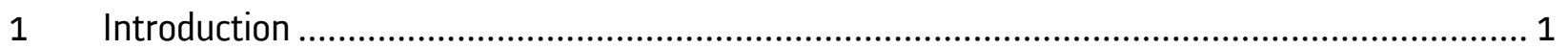

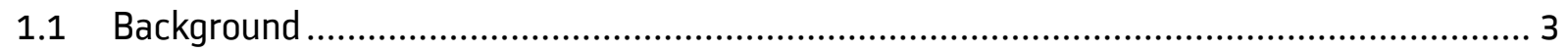

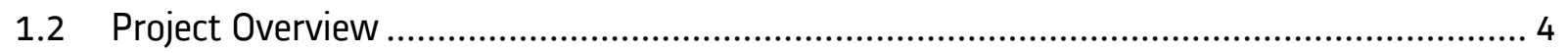

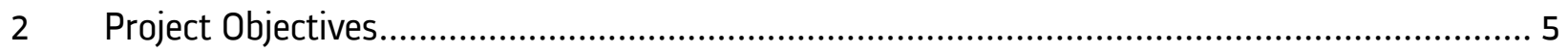

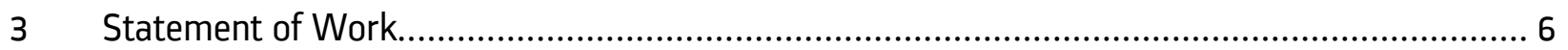

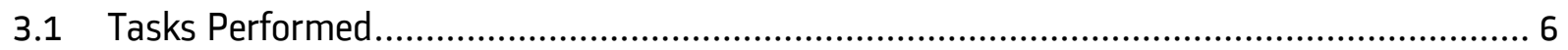

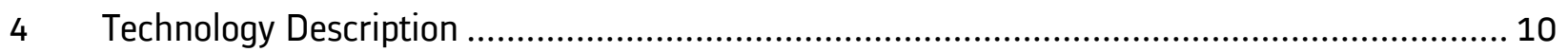

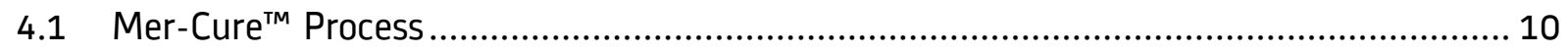

4.2 Mobile Mer-Cure ${ }^{\mathrm{TM}}$ Demonstration System ............................................................ 11

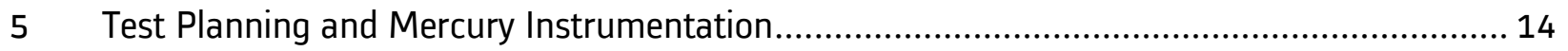

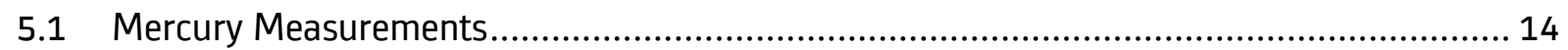

$6 \quad$ Fayette Unit \#3 Demonstration Program.................................................................. 17

6.1 Site Description and Test Preparation ..................................................................... 17

6.2 Baseline Testing Results ...................................................................................... 22

6.3 Parametric Testing Results .................................................................................. 25

6.4 Ash Evaluation Testing Results and Balance of Plant Impacts..................................... 26

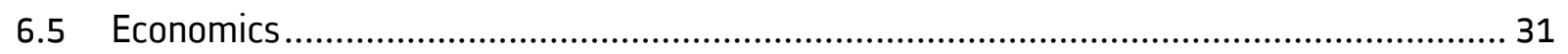

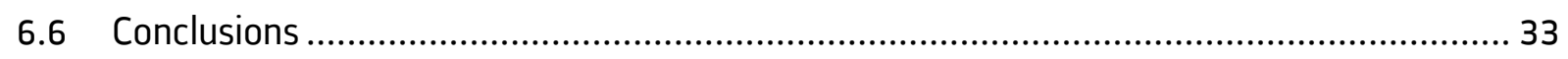

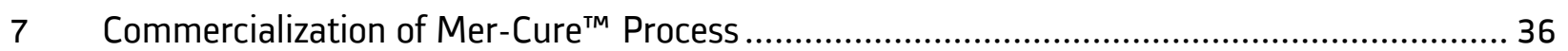

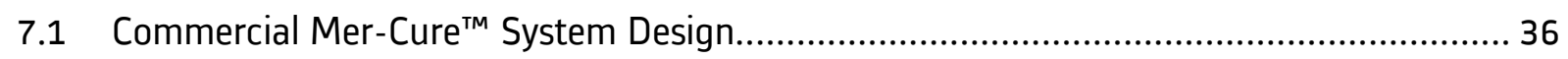

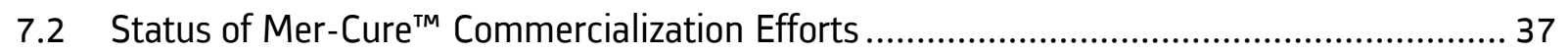

8 Summary of Demonstration Program Results .............................................................. 38

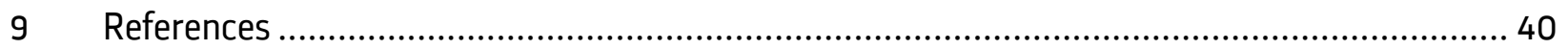

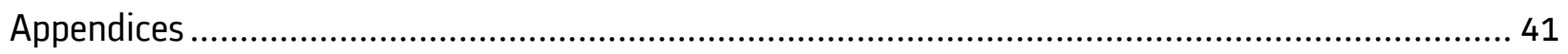

Appendix A Ontario Hydro and Sorbent Trap Test Results ................................................A1-A2

Appendix B CMM Screens........................................................................................ B B

Appendix C Test Schedule, Coal and Ash Analyses............................................................. (1-C31 


\section{List of Figures}

Figure i-1 Mercury Capture Results for Demonstration Project Host Sites .....................................

Figure i-2 Mercury Removal Costs for Demonstration Project Host Sites ......................................xi

Figure 4.1-1 Alstom's Mer-Cure ${ }^{\mathrm{TM}}$ Technology for Mercury Capture............................................ 10

Figure 4.2-1 Mobile Mer-Cure ${ }^{\mathrm{TM}}$ Demonstration Trailer Schematic ............................................ 11

Figure 4.2-2 Mobile Mer-Cure ${ }^{\mathrm{TM}}$ System Upgraded Transport Air Blowers ................................... 11

Figure 4.2-3 On Site Assembly of Mobile Mer-Cure ${ }^{\mathrm{TM}}$ Demonstration Trailer................................ 12

Figure 4.2-4 Moblie Mer-Cure ${ }^{\mathrm{TM}}$ Trailer Installed at Fayette Unit \#3 ............................................ 13

Figure 5.1-1 Inertial Separation Probe at Air Preheater inlet CMM Location ................................. 15

Figure 5.1-2 Ontario Hydro Sample Train Schematic ............................................................... 16

Figure 6.1-1 Flue Gas Flow Distribution at Fayette Unit \#3 Injection Location.............................. 18

Figure 6.1-2 02 Distribution at 02 Probe Location With Injection Lances in Operation.................. 19

Figure 6.1-3 Flow Distribution around Fayette Unit \#3 FGD Modules.......................................... 19

Figure 6.1-4 Fayette Unit \#3 Injection Lances and Distributor Installed at AH Inlet ...................... 20

Figure 6.1-5 Sorbent Treatment and Sampling Locations, Fayette Unit \#3 ................................. 21

Figure 6.2-1 Comparison Between Coal Mercury Content and CMM Reading at AH Inlet .............. 23

Figure 6.2-2 Baseline Total Mercury Readings from CMMs at Three Locations ............................. 24

Figure 6.2-3 Mercury Speciation Data at the ESP outlet and Stack............................................ 24

Figure 6.3-1 CMM Response to Mer-Cure ${ }^{\mathrm{TM}}$ Sorbent Injection at Fayette Unit \#3 .......................... 25

Figure 6.3-2 Parametric Test Results of Mer-Cure ${ }^{\mathrm{TM}}$ System at Fayette Unit \#3 (based on

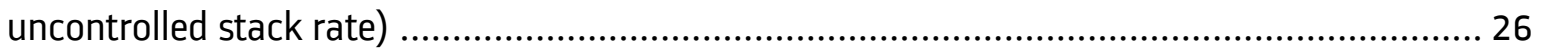

Figure 6.4-1 Foam Index Chart for LCRA Ash-sorbent Samples ................................................. 27

Figure 6.4-2 Continuous Injection of Mer-Clean ${ }^{\text {TM }} 8$ Sorbent for Ash Evaluation ............................ 28

Figure 6.4-3 Continuous Injection of eSorb ${ }^{\mathrm{TM}} 11$ Sorbent for Ash Evaluation................................. 29

Figure 6.4-4 Parametric Test Results of Mer-Cure ${ }^{\mathrm{TM}}$ System at Fayette Unit \#3 (based on coal mercury content) ......................................................................................................... 29

Figure 6.4-5 Measured Fayette Unit \#3 Opacity During Test Period............................................... 30

Figure 6.5-1 Sensitivity analysis: Effect of Sorbent Unit Cost and Mercury Removal Required on Operating Cost for Mercury Control for LCRA Fayette Unit \#3 using Mer-Cure ${ }^{\mathrm{TM}}$ technology.. 33

Figure 6.6-1 Mercury Reduction Performance Summary for Fayette Unit \#3 ................................. 34

Figure 6.6-2 Mercury Removal Costs for LCRA Fayette Unit \#3 ................................................. 35 


\section{List of Tables}

Table 1.1-1 Host Site, Coal and Emission Data for the Field Demonstration ................................. 2

Table 1.2-1 Overall Program Schedule .................................................................................. 4

Table 3.1-1 Summary of Short-Term Demonstration Plan ............................................................ 8

Table 6.1-1 LCRA Fayette Unit \#3 Average Coal Properties......................................................... 22

Table 6.1-2 LCRA Fayette Unit \#3 Test Campaign Timeline........................................................ 22

Table 6.4-1 LCRA Fayette Unit \#3 Ash Leaching Test Results.................................................... 30

Table 6.5-1 Capital, Operating and Maintenance Cost Estimate for Alstom's Mer-Cure ${ }^{\mathrm{TM}}$ Technology Implementation at Fayette Unit \#3 for 90 Percent Mercury Reduction ................................ 31

Table 6.5-2 Sorbent Consumption Rates as a Function of Mercury Removal Level for Mer-Cure ${ }^{\mathrm{TM}}$

Technology Implementation at Fayette Unit \#3 ............................................................ 32 


\section{List of Abbreviations}

$\begin{array}{ll}\text { BOP } & \text { balance of plant } \\ \text { CFD } & \text { computational fluid dynamics } \\ \text { CMM } & \text { continuous mercury monitor } \\ \text { DOE } & \text { U.S. Department of Energy } \\ \text { UND EERC } & \text { University of North Dakota Energy and Environmental Research Center } \\ \text { ESP } & \text { electrostatic precipitator } \\ \text { LCRA } & \text { Lower Colorado River Authority } \\ \text { LOI } & \text { loss on ignition } \\ \text { NETL } & \text { National Energy Technology Laboratory } \\ \text { OH } & \text { Ontario Hydro } \\ \text { PAC } & \text { powdered activated carbon } \\ \text { PC } & \text { pulverized coal } \\ \text { PRB } & \text { Powder River Basin } \\ \text { PSA } & \text { PS Analytical } \\ \text { QA } & \text { quality assurance } \\ \text { QC } & \text { quality control } \\ \text { SCA } & \text { specific collection area } \\ \text { UBC } & \text { unburned carbon }\end{array}$




\section{Executive Summary}

Alstom was awarded a DOE/NETL-sponsored project under "Mercury Round 3" (DOE Cooperative Agreement No. DE-FC26-07NT42776) to perform full-scale demonstration of its Mer-Cure ${ }^{\mathrm{TM}}$ technology in two coal-fired boilers burning coals of various ranks. The full-scale demonstration program originally included test campaigns at two host sites: Lower Colorado River Authority's (LCRA's) 480-MW Fayette Unit \#3 and Reliant Energy's 190-MW $\mathrm{MW}_{\mathrm{e}}$ Shawville Unit \#3. The only demonstration tests actually done were the short-term tests LCRA due to budget constraints. This report gives a summary of the demonstration testing at Fayette Unit \#3.

Mer-Cure ${ }^{\mathrm{TM}}$ technology is a treated sorbent-based mercury control technology. This technology has been developed based on a mechanistic understanding of the critical areas that need to be augmented for mercury oxidation and capture. The technology has progressed through wellcontrolled laboratory-scale testing, pilot-scale testing, and DOE/NETL-sponsored full-scale test programs.

In Alstom's Mer-Cure ${ }^{\mathrm{TM}}$ mercury control technology, a small amount of sorbent is injected into the flue gas stream for oxidation and adsorption of gaseous mercury. The sorbents are activated carbonbased and prepared with chemical additives that promote oxidation and capture of elemental mercury. The technology is unique in that the sorbent is injected into a high temperature (above $700^{\circ} \mathrm{F}$ ) environment where the mercury oxidation/removal kinetics are accelerated.

The report concludes that Mer-Cure ${ }^{T M}$ technology, using Mer-Clean ${ }^{T M}$ sorbent(s), is both a cost and performance effective means of controlling mercury emissions. Mer-Cure ${ }^{\mathrm{TM}}$ technology was also successfully applied to alternative sorbent products in this project.

\section{Background}

This field demonstration program had two host sites for full-scale demonstration to obtain the required information for assessing the technical feasibility and determining the mercury capture performance and costs of controlling mercury in coal-fired utility plants using Mer-Cure ${ }^{\mathrm{TM}}$ technology. The two sites were selected to represent boilers with specific mercury capture issues. Fayette Unit \#3 was selected to evaluate the effect of mercury control on fly ash utilization for concrete, and Shawville Unit \#3 was selected to evaluate the effect of high $\mathrm{SO}_{3}$ levels on mercury capture performance. The program was designed to document the performance of the Mer-Cure ${ }^{\mathrm{TM}}$ technology using both Mer-Clean ${ }^{\mathrm{TM}}$ sorbent and alternative sorbents to determine their $\mathrm{SO}_{3}$ tolerance and "concrete-friendly" characteristics.

The overall objective of the work was to perform two- to six-month, full-scale demonstrations of Mer-Cure ${ }^{\mathrm{TM}}$ technology in two coal-fired boilers. The goals of the Mercury Round 3 program, as originally defined by DOE/NETL in the solicitation, are to demonstrate that Mer-Cure ${ }^{\mathrm{TM}}$ technology can achieve:

- Greater than $90 \%$ reduction of gaseous mercury in the flue gas;

- At a mercury control cost significantly lower than $50 \%$ of $\$ 60,000 /$ lb mercury removed. 
Alstom-PPL also collected performance data to evaluate the long-term impact of mercury control on the operation of power plants and overall plant economics, including information desired by LCRA on the maximum mercury reduction possible while maintaining the ability to sell their fly ash for concrete applications.

\section{Work Scope}

In order to accomplish the technical objectives, a technical approach was utilized to effectively demonstrate and evaluate Alstom-PPL mercury control technology. Testing at each demonstration site was planned to include both a five week long short-term and two to six month long long-term, full-scale test campaign. The work required for the test campaigns can be broken down to the following tasks:

- Task 1. Design, Engineering and Fabrication of System

- Subtask 1.1 Design and Engineering of System Architecture

- Subtask 1.2 Component Fabrication and System Assembly

- Task 2. Short-Term Demonstration

- Subtask 2.1 Project Planning

- Subtask 2.2 Design, Fabrication and Maintenance of Site-Specific System

- Subtask 2.3 Installation of Mobile Mer-Cure ${ }^{\mathrm{TM}}$ System

- Subtask 2.4 Parametric Testing

- Task 3 Long-Term Field Demonstration

- Subtask 3.1 Installation, Checkout and Commissioning

- Subtask 3.2 Field Testing and Measurement

- Subtask 3.3 System Removal

- Subtask 3.4 Data Analysis and Site Report

- Task 4. Technology Transfer

- Task 5. Program Management and Reporting.

Alstom-PPL engineers at Alstom-PPL's Windsor site performed most of the Task 1 work. Tasks 2 and 3 were to be repeated for both host sites. Alstom-PPL engineers performed Task 2 with the assistance of host site personnel and EERC measurement crew. The five week short-term test campaign at Fayette Unit \#3 took place in March and April of 2007. Tasks 4 and 5 were performed by Alstom-PPL throughout the performance period to support the entire demonstration program. The EERC and LCRA also provided input to the tasks.

Tasks 2 and 3 at Shawville Unit \#3 and Task 3 at Fayette Unit \#3 were never performed due to funding constraints.

\section{Field Demonstration Mercury Capture Results}

The first performance goal for this project was at least 90\% reduction in uncontrolled stack emissions of mercury. The mercury capture results for Fayette Unit \#3 are shown in Figure i-1. Two of the four sorbents tested achieved $90 \%$ mercury reductions, and the other two sorbents were not tested at injection rates above $0.5 \mathrm{lb} / \mathrm{MMacf}$ because of time constraints. In the ash evaluation tests, Foam 
Index Test measurements indicated that the ash generated with sorbent injection to achieve 90\% mercury reductions would likely be unsuitable for concrete applications. Figure i summarizes the parametric test mercury reduction results, the maximum mercury reduction demonstrated, and the maximum mercury reduction possible while maintaining ash quality for sale.

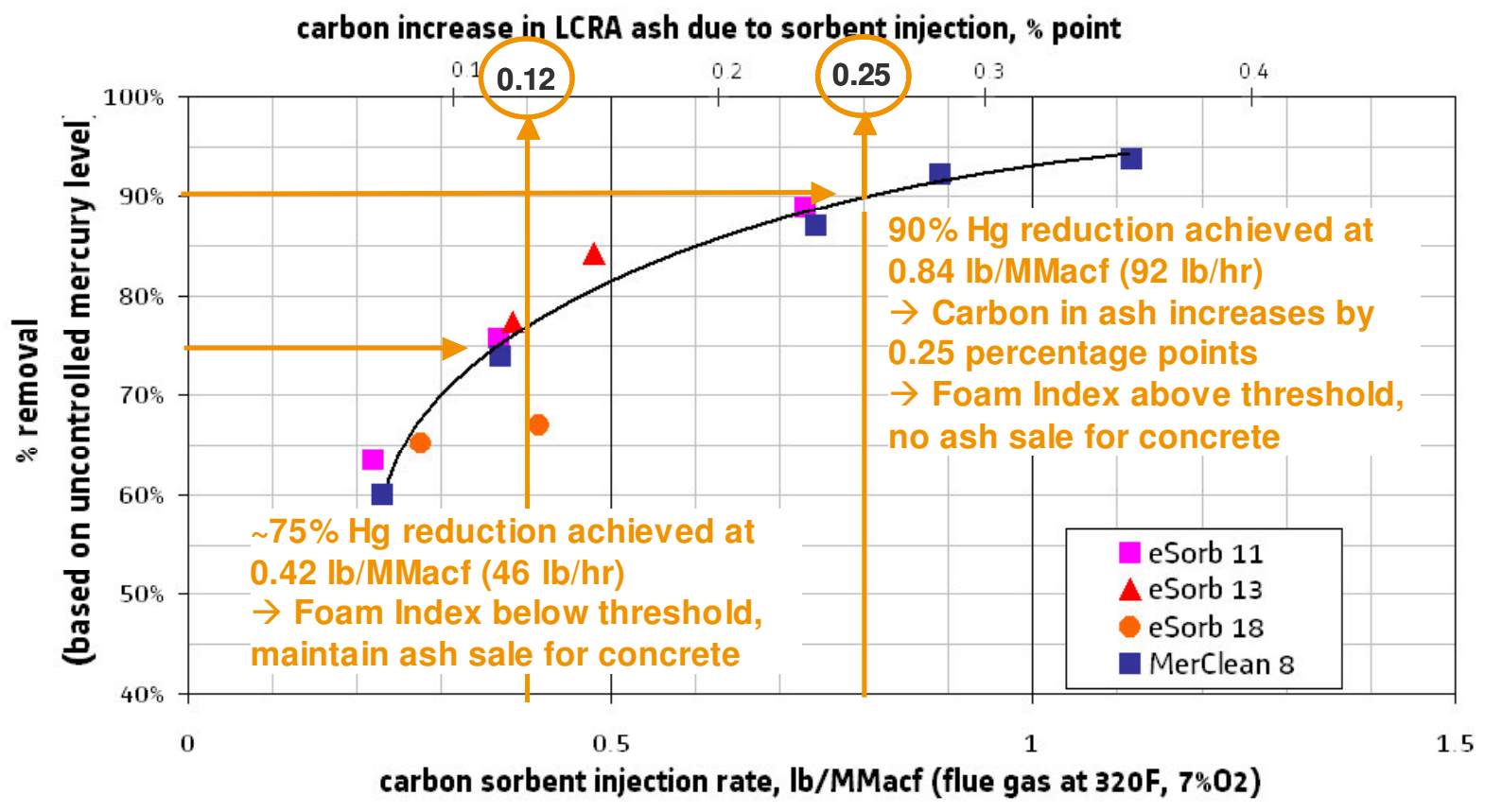

Figure i-1 Mercury Capture Results for Demonstration Project Host Sites

Note that mercury reductions above $90 \%$ were demonstrated, achieving the original project goals. Mercury reductions of $75 \%$ were also demonstrated while maintaining fly ash quality for concrete applications.

\section{Engineering System Analysis and Economics}

The second performance goal was achieving $90 \%$ mercury reduction at a mercury removal cost significantly lower that $50 \%$ of the assumed baseline cost of $\$ 60,000 / \mathrm{lb}$ mercury removed.

The mercury removal costs in $\$ / \mathrm{lb} \mathrm{Hg}$ removed are summarized in Figure i-2. The figure shows very low removal costs for $75 \%$ reduction because only $46 \mathrm{lb} / \mathrm{hr}$ sorbent is required and testing indicated that the fly ash sale for concrete could be maintained. The removal costs at $90 \%$ reduction levels are significantly higher. Sorbent costs are doubled, because $92 \mathrm{lb} / \mathrm{hr}$ sorbent flow is required to achieve $90 \%$ reduction, but the inability to sell ash for concrete accounts for the majority of the cost increase. Even with the ash effects, the removal costs at $90 \%$ reduction are over $70 \%$ below the baseline cost of $\$ 60,000 / \mathrm{lb} \mathrm{Hg}$ removed at sorbent costs below $\$ 2.00 / \mathrm{lb}$. Even at $\$ 2.00 / \mathrm{lb}$ sorbent, the removal cost is $\$ 18,700 / \mathrm{lb}$ or $68.8 \%$ below $\$ 60,000 / \mathrm{lb} \mathrm{Hg}$ removed.

Mercury levels were reduced $90 \%$ at a cost at least $68.8 \%$ below the baseline cost, achieving the second performance goal for this project. 


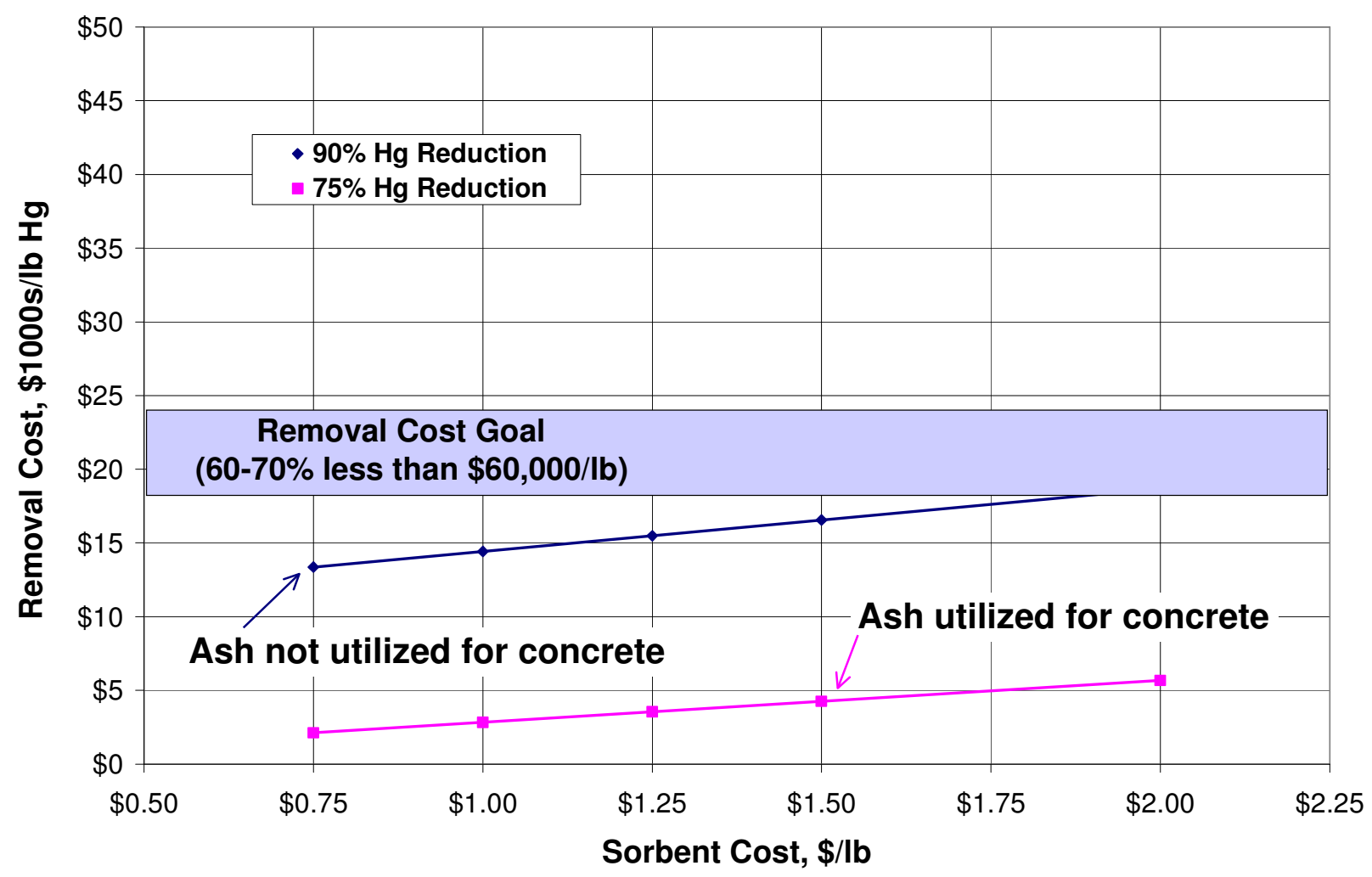

Figure i-2 Mercury Removal Costs for Demonstration Project Host Sites

\section{Balance of Plant Impacts}

Observations throughout the testing suggest that injection of Mer-Clean ${ }^{\mathrm{TM}}$ sorbent did not increase the stack opacity during long-term testing. Ash leaching test results indicated that no detectable mercury leached from the fly ash.

The unburned carbon in the fly ash increased, and the increase was related to the amount of sorbent injected. At $46 \mathrm{lb} / \mathrm{hr}$ sorbent injection rate, unburned carbon in the ash increased by 0.12 percentage points. At $92 \mathrm{lb} / \mathrm{hr}$ sorbent injection rate, unburned carbon in the ash increased by 0.25 percentage points. 


\section{Introduction}

Various methods for mercury control in coal-fired power plants are being developed and demonstrated to meet current and impending mercury emission regulations. ${ }^{1,2}$ These technologies range from activated carbon $(A C)$ injection, coal and flue gas additives, catalytic and electro-catalytic mercury oxidation with subsequent capture in scrubbers, and in-situ mercury sorbent generation from coal. Among these, powdered AC injection is one of the more mature technologies for mercury control.

In previous Round 1 demonstration projects, it was observed that very high injection rates (6-15 $\mathrm{lb} / \mathrm{MMacf})^{1}$ of plain AC were needed to achieve reasonable levels of mercury removal, particularly for low-chlorine containing sub-bituminous (Powder River Basin or PRB) and lignite coals. The low removal levels could be ascribed to a high proportion of elemental mercury in the flue gas when firing these coals. Researchers and technology developers have since used halogenated carbon sorbents to address this problem, with improved performance compared to plain AC (3.3 to 6 $\mathrm{lb} /$ MMacf injection rate for $90 \%$ removal) ${ }^{1,2}$

Alstom was awarded a DOE/NETL-sponsored project (DOE Cooperative Agreement DE-FC2607NT42776) to perform full-scale demonstration of its Mer-Cure ${ }^{T M}$ technology in two coal-fired boilers burning coals of various ranks. In the full-scale demonstration program, Alstom-PPL teams up with the Lower Colorado River Authority (LCRA), Reliant Energy, and the University of North Dakota-Energy and Environmental Research Center (UND-EERC).

The overall objective of the work is to perform two- to six-month, full-scale demonstrations of MerCure $^{\mathrm{TM}}$ technology in two coal-fired boilers. The goals of the Mercury Round 3 program, as originally defined by DOE/NETL in the solicitation, are to demonstrate that Mer-Cure ${ }^{\mathrm{TM}}$ technology can achieve:

- Greater than 90\% reduction of gaseous mercury in the flue gas;

- At a mercury control cost significantly lower than $50 \%$ of $\$ 60,000 /$ lb mercury removed.

Alstom-PPL also collected performance data to evaluate the long-term impact of mercury control on the operation of power plants and overall plant economics, including information desired by LCRA on the maximum mercury reduction possible while maintaining the ability to sell their fly ash for concrete applications.

The two test sites selected for the demonstration program are LCRA's Fayette Unit \#3 and Reliant Energy's Shawville Unit \#3. Detailed descriptions of the two proposed host sites are provided in Table 1.1-1. LCRA's Fayette Unit \#3 is located in La Grange, TX, and fires PRB coal blends. The unit has a $480-\mathrm{MW}_{\mathrm{e}}$ boiler and is equipped with two Ljungstrom $^{\mathrm{TM}}$ air heaters, two electrostatic precipitators (ESPs) and followed by a wet scrubber system with three modules. The ESP ash from the unit is currently sold to ash marketers. In the Fayette Unit \#3 test campaign, Alstom-PPL will address the effect of sorbent injection on ash utilization.

Reliant Energy's test site is Shawville Unit \#3 in Shawville, PA. The unit is a 190-MW (gross) boiler with two Ljungstrom air heaters and two ESP's for particulate control. The unit currently fires 
medium-sulfur Eastern bituminous coals with average sulfur content of $2 \%$. The mercury level at the stack ranged from 15 to $20 \mathrm{mg} / \mathrm{Nm3}$. In the Shawville Unit \#3 campaign, Alstom-PPL will focus on the effect of $\mathrm{SO}_{3}$ in the flue gas on mercury capture.

The EERC will provide mercury measurement expertise. Continuous mercury monitors (CMMs) will be used throughout the test period to provide both elemental and oxidized mercury concentrations in the flue gas. Ontario Hydro method will be used for some of the key test conditions to verify CMM data.

Table 1.1-1 Host Site, Coal and Emission Data for the Field Demonstration

\begin{tabular}{|c|c|c|}
\hline & LCRA & Reliant Energy \\
\hline Unit & Fayette Unit \#3 & Shawville Unit \#3 \\
\hline Location & La Grange, TX & Shawville, PA \\
\hline Capacity (MW $\mathrm{e}_{\mathrm{e}}$ Gross) & 480 & 190 \\
\hline Operation & Baseload & Cycling \\
\hline $\mathrm{NO}_{\mathrm{x}}$ and $\mathrm{SO}_{2}$ control & $\begin{array}{l}\text { Low NOx firing/ } \\
\text { wet scrubber }\end{array}$ & $\begin{array}{l}\text { Low NOx } \\
\text { firing/SNCR }\end{array}$ \\
\hline Air Heater & Two Ljungstrom ${ }^{\mathrm{TM}}$ & Two Ljungstrom ${ }^{\mathrm{TM}}$ \\
\hline $\begin{array}{l}\text { Particulate control } \\
\left(\mathrm{SCA} \text { in } \mathrm{ft}^{2} / \mathrm{kacfm}\right)\end{array}$ & $\begin{array}{l}\text { Two ESP's } \\
(640)\end{array}$ & $\begin{array}{l}\text { Four ESP's } \\
\text { (312 total) }\end{array}$ \\
\hline Ash utilization & Sold & Landfilled \\
\hline Coal & PRB blends & E. bituminous coal \\
\hline $\begin{array}{l}\text { Higher Heating Value, } \\
\text { As-rcvd (Ib/MMBtu) }\end{array}$ & $8,000-8,500$ & $11,000-13,000$ \\
\hline Sulfur (\%) & $0.3-0.5$ & $1.8-2.2$ \\
\hline Ash (\%) & 4-6 & $12-15$ \\
\hline $\mathrm{Cl}$ in coal (ppmwd) & $20-50$ & $720-1320$ \\
\hline $\mathrm{Hg}$ in coal (ppmwd) & $0.1-0.2$ & $0.3-0.63$ \\
\hline $\begin{array}{l}\text { Uncontrolled } \mathrm{Hg} \text { Stack } \\
\left(\mathrm{Hg}^{\top}, \mathrm{Hg}^{\mathrm{p}}, \mathrm{Hg}^{\mathrm{ox}}, \mathrm{Hg}^{\mathrm{el}}\right) \\
\left(\mu \mathrm{g} / \mathrm{Nm}^{3}\right)\end{array}$ & $\begin{array}{l}11.4 \text { (total), } \\
(97 \% \text { as elemental } \\
\mathrm{Hg})\end{array}$ & $\begin{array}{l}18-22 \text { (total) } \\
\text { (50-70\% oxidized) }\end{array}$ \\
\hline Carbon-in-ash (\%) & 0.18 & $4-6$ \\
\hline $\begin{array}{l}\text { Flue gas temperature } \\
\left(\text { ESP Inlet, }{ }^{\circ} \mathrm{F}\right)\end{array}$ & 310 & 280 \\
\hline
\end{tabular}

Each of these boilers is equipped with a cold-side electrostatic precipitator (ESP) for particulate control. This report gives a summary of the demonstration testing at Fayette Unit \#3, the only site tested because of budgetary constraints of the Mercury Round 3 program.

Mer-Cure ${ }^{\mathrm{TM}}$ is a treated sorbent-based mercury control technology. This technology has been developed based on a mechanistic understanding of the critical areas that need to be augmented for mercury oxidation and capture and scaled up from well-controlled laboratory-scale testing, pilot- 
scale testing, and through a short-term demonstration at a $220 \mathrm{MW}_{\mathrm{e}}$ pulverized coal-fired boiler. Alstom is also developing other technologies for mercury control in coal-fired boilers, including coal additives $\left(\mathrm{KNX}^{\mathrm{TM}}\right)$ and traditional carbon injection with the addition of a polishing fabric filter ${ }^{6}$

\subsection{Background}

In Alstom's Mer-Cure ${ }^{\mathrm{TM}}$ mercury control technology, a small amount of sorbent is injected into the flue gas stream for oxidation and adsorption of gaseous mercury. The sorbents are activated carbonbased and prepared with chemical additives that promote oxidation and capture of elemental mercury. The technology is unique in that the sorbent is injected into a high temperature (above $700^{\circ} \mathrm{F}$ ) environment where the mercury oxidation/removal kinetics are accelerated.

Mer-Cure ${ }^{\mathrm{TM}}$ mercury control technology applied to coal-fired power generation has the potential to be a cost-effective mercury control technology for the entire range of coals (bituminous, subbituminous, and lignite). As the technology is based on oxidation and adsorption of mercury, it is also applicable to all air pollution control configurations including wet scrubber and spray dryerESP/baghouse units. The main focus of this project, however, is with a cold-side ESP as the particulate control device. Cold-side ESPs represent over $70 \%$ of the coal-fired boilers in the United States. The mercury control technology has low-capital costs $\left(\$ 5-10 / \mathrm{kW}_{\mathrm{e}}\right)$. It also requires a very small amount of low-cost additives for treatment, which results in low operating costs (0.5-0.75 mills/kWh) and minimal balance-of-plant (BOP) impact.

The Mer-Cure ${ }^{\mathrm{TM}}$ system takes advantage of a mechanistic understanding of mercury oxidation and capture to identify the critical areas that need to be augmented to maximize mercury oxidation and capture. The approach for enhanced mercury capture is:

- Pre-treatment of activated carbon (AC)-based sorbent with proprietary additive and its injection into the high temperature region $\left(400\right.$ to $\left.800^{\circ} \mathrm{F}\right)$. This activates the additive on the carbon and makes it reactive with elemental mercury;

- Accelerated reaction (due to the high temperature) of adsorbed mercury with the activated additive to an oxidized product and its retention; and

- Injection methodology that ensures dispersion and uniform distribution of sorbent in the flue gas and minimizes mixing limitation;

- Capture of sorbent particle with adsorbed mercury in an ESP or fabric filter.

Mer-Clean $^{\mathrm{TM}}$ is a carbon-based sorbent with a proprietary additive that accelerates mercury oxidation by providing the oxidation reaction partner in high concentrations on the carbonaceous particle. MerCure $^{\mathrm{TM}}$ technology has also been successfully applied to alternative commercially available sorbent products.

More importantly, Mer-Cure ${ }^{T M}$ technology involves injection at an "ideal" temperature location, which allows contact with the elemental mercury to begin as early as it can be effective. This is typically in the duct leading to the air heater. Higher temperature also increases reaction rates exponentially. This enables maximum utilization of the entire effective temperature range for oxidation with the added sorbent. In contrast to the Mer-Cure ${ }^{\mathrm{TM}}$ system, current practice involves 
the injection of carbon sorbents at low temperatures downstream an air heater, where typical temperatures are between 250 and $350^{\circ} \mathrm{F}$. In this case, the contact time between the sorbent and the mercury in the flue gas is significantly shorter and the added benefit of accelerated kinetics at a higher temperature is not available.

In connection with injection at higher temperatures is the unique and proprietary nature of MerClean $^{\mathrm{TM}}$. Careful selection of the additive and method by which it is administered to the sorbent ensures that the sorbent-additive combination becomes active and retains its integrity through the high temperature range. In addition, Mer-Cure ${ }^{\text {TM }}$ technology has also been successfully applied to alternative commercially available sorbent products.

Finally, detailed computational flow modeling of the injection region is performed to match the injection system to local flow conditions. In this manner, uniform distribution of sorbent is achieved before the flue gases enter the air heater. Sorbent distribution is critical to minimize the amount of sorbent required for a given performance level.

\subsection{Project Overview}

The full-scale demonstration program originally included test campaigns at two host sites: LCRA's 480-MW Fayette Unit \#3 (FPP3) burning PRB blends, and equipped with an ESP and a wet scrubber; and Reliant Energy's 190-MW $\mathrm{MW}_{\mathrm{e}}$ Shawville Unit \#3 burning Eastern bituminous coal, and equipped with two Ljungstrom air heaters and two ESP's in series. The demonstration program as proposed included a two- to five-week short-term field test followed by two-month long-term demonstration for each of the two selected sites.

Project funding was approved by the DOE/NETL for budget period 1. During budget period 1, a short-term demonstration at the LCRA's Fayette Unit \#3 was performed. Unfortunately, the remainder of the Mercury Round 3 project was cancelled due to budgetary constraints. Therefore, the only tests performed under this project were the short term tests at Fayette Unit \#3. Table 1.2-1 shows the overall program short-term and long-term testing schedule as originally defined, with the cancelled tasks in red. A detailed description of the statement of work actually performed is included for completeness in Section 3.

Table 1.2-1 Overall Program Schedule

\begin{tabular}{|c|c|c|c|c|c|c|c|c|c|c|c|c|c|c|c|c|c|c|}
\hline \multirow[t]{2}{*}{ Site } & \multicolumn{12}{|c|}{2007} & \multicolumn{6}{|c|}{2008} \\
\hline & J & $\mathrm{F}$ & M & A & M & 1 & $J$ & A & $S$ & 0 & $\mathrm{~N}$ & D & $J$ & $\mathrm{~F}$ & M & A & $M$ & 1 \\
\hline \multicolumn{19}{|l|}{ Fayette Unit \#3 } \\
\hline Shawville Unit \#3 & & & & & & & & & & & & & & & & & & \\
\hline
\end{tabular}




\section{Project Objectives}

The overall objective of the proposed work is to develop a mercury control technology in coal-fired boilers that can achieve more than 90\% mercury capture. In Alstom's Mer-Cure ${ }^{\mathrm{TM}}$ mercury control technology, sorbents with chemical additives that promote oxidation and capture of elemental mercury are injected into an environment where the kinetics are favorable. Installation of MerCure $^{\mathrm{TM}}$ technology has low-capital costs $\left(\$ 5-10 / \mathrm{kW}_{\mathrm{e}}\right)$. The mercury control technology also requires a very small amount of sorbent, which results in low operating costs (0.5-0.75 mills/kWh) and minimal Balance of Plant (BOP) impact.

The goals of the program, as originally defined by DOE/NETL in the solicitation, are to demonstrate that Mer-Cure ${ }^{\mathrm{TM}}$ technology can achieve:

- Greater than 90\% reduction of gaseous mercury in the flue gas;

- At a mercury control cost significantly lower than $50 \%$ of $\$ 60,000 /$ lb mercury removed.

Alstom-PPL also collected performance data to evaluate the long-term impact of mercury control on the operation of power plants and overall plant economics, including information desired by LCRA on the maximum mercury reduction possible while maintaining the ability to sell their fly ash for concrete applications.

Alstom-PPL is committed to offer the most economically viable mercury control solution to our utility customers while minimizing the impact on the overall power plant economics, and Mer-Cure ${ }^{\mathrm{TM}}$ technology offers a great opportunity for utility companies to control mercury in the most costeffective manner. Alstom-PPL is committed to commercialize the technology and believes that the completed full-scale demonstration of the technology was a critical step to successful commercialization. 


\section{Statement of Work}

In order to accomplish the technical objectives, a technical approach was utilized to effectively demonstrate and evaluate Alstom-PPL mercury control technology. Testing at each demonstration site was planned to include both a five week short-term and two month long-term, full-scale test campaign. The work required for the test campaigns can be broken down to the following tasks:

- Task 1. Design, Engineering and Fabrication of System

- Subtask 1.1 Design and Engineering of System Architecture

- Subtask 1.2 Component Fabrication and System Assembly

- Task 2. Short-Term Demonstration

- Subtask 2.1 Project Planning

- Subtask 2.2 Design, Fabrication and Maintenance of Site-Specific System

- Subtask 2.3 Installation of Mobile Mer-Cure ${ }^{\text {TM }}$ System

- Subtask 2.4 Parametric Testing

- Task 3 Long-Term Field Demonstration

- Subtask 3.1 Installation, Checkout and Commissioning

- Subtask 3.2 Field Testing and Measurement

- Subtask 3.3 System Removal

- Subtask 3.4 Data Analysis and Site Report

- Task 4. Technology Transfer

- Task 5. Program Management and Reporting.

Alstom-PPL engineers at Alstom-PPL's Windsor site performed most of the Task 1 work. Tasks 2 and 3 were to be repeated for both host sites. Alstom-PPL engineers performed Task 2 with the assistance of host site personnel and EERC measurement crew. The five week short-term test campaign at Fayette Unit \#3 took place in March and April of 2007. Tasks 4 and 5 were performed by Alstom-PPL throughout the performance period to support the entire demonstration program. The EERC and the participating utility companies also provided input to the tasks.

Tasks 2 and 3 at Shawville Unit \#3 and Task 3 at Fayette Unit \#3 were never performed due to funding constraints. Therefore, Task 3 is not described in the following section.

\subsection{Tasks Performed}

Detailed description of the tasks and subtasks listed in Section 3 are presented in the following paragraphs.

\section{Task 1 Design, Engineering and Fabrication of System}

Alstom-PPL has a mobile Mer-Cure ${ }^{\mathrm{TM}}$ unit developed under Mercury Round 2 that was employed for the Round 3 demonstration. In this task, the system was modified and upgraded to provide adequate capacity and enhanced performance for the project. 


\section{Subtask 1.1 Design and Engineering of System Architecture}

The current mobile Mer-Cure ${ }^{\mathrm{TM}}$ unit was designed for shorter term testing at smaller units of up to $220 \mathrm{MW}_{\mathrm{e}}$. The testing at LCRA's Fayette Unit \#3 required treatment of the entire flue gas stream coming from a $480-\mathrm{MW}_{\mathrm{e}}$ boiler. This was accomplished by designing an upgraded the transport air system. A blower system was designed as part of the upgraded transport air system for increased pneumatic capacity. This allowed injection of sorbent into a larger volume of flue gas while not requiring any additional electrical services installed at the host sites.

\section{Subtask 1.2 Component Fabrication and System Assembly}

System modifications and upgrades identified in Subtask 1.1 were implemented into the existing mobile unit. Most of the system components were fabricated and assembled at Alstom - PPL's site in Windsor, CT. The system design was modular so that maintenance and modification, if necessary, could be made quickly.

\section{Task 2 Short-Term Demonstration}

In this task, Alstom-PPL collected short-term performance data of our mercury control technology from the host site boilers for evaluation by DOE/NETL and the team. The task was further broken down to the following.

\section{Subtask 2.1 Project Planning}

The success of the project was very dependent on close and smooth coordination with various team members throughout the performance period. In the planning stage, Alstom-PPL communicated closely with the plant personnel of the host sites and the mercury measurement crew of the EERC.

Alstom-PPL held meetings with plant and corporate personnel to design and discuss the detailed test plan. In these meetings, any potential operational issues of the plant and plant equipment were thoroughly discussed. Also, plant data acquisition was coordinated with the operational crew. Alstom worked with the environmental personnel to help obtain permits for the testing from the state Department of Environmental Protection. Alstom also coordinated closely with EERC for a sound measurement plan. The EERC provided personnel and equipment to obtain continuous mercury concentrations using two $\mathrm{CMMs}$ and Ontario Hydro $(\mathrm{OH})$ measurements upstream of injection locations and downstream of the ESPs and/or scrubber. The team members collaborated to develop a QA/QC plan on the overall test program.

\section{Subtask 2.2 Design, Fabrication and Maintenance of Site-Specific System}

The mobile Mer-Cure ${ }^{T M}$ system developed under Mercury Round 2 was employed for this task. As part of the task, the mobile Mer-Cure ${ }^{\mathrm{TM}}$ system was modified to accommodate site-specific circumstances. For example, the injection system, e.g., lances and nozzles, were designed based on computational fluid dynamics (CFD) studies of the flue gas flows in the sorbent injection area.

The subtask began with an initial visit to the host sites for preliminary site evaluation. At the sites, Alstom-PPL engineers and site personnel thoroughly reviewed plant arrangements, accessibility of testing-related sections of the plant, site operations, and other plant data available. This initial 
review of site-specific information led to an optimized design of the mobile Mer-Cure ${ }^{\mathrm{TM}}$ system, the test plan, and its ensured adequacy and integrity at the specified sites. Any safety issues were also addressed.

\section{Subtask 2.3 Installation of Mobile Mer-Cure ${ }^{\mathrm{TM}}$ System}

The mobile Mer-Cure ${ }^{T M}$ system, mounted on a 48-ft trailer, was shipped and installed at the test site. Any required plant modifications (such as installation of injection/sampling ports or catwalks, etc.) were completed during plant outage prior to testing. Structural and electrical interfaces with the boiler were made. Finally, system shakedown was conducted to ensure system operability.

While the Mer-Cure ${ }^{\mathrm{TM}}$ system was installed, the EERC crew set up the CMMs at the predetermined locations. For continuous measurement of gaseous mercury, the flue gas was sampled with inertial separation probes (ISP) for removing flyash and analyzed by CMMs such as PS Analytical, Tekran, and Horiba. The CMM assembly was housed in a clean, temperature-controlled environment. Operated under a well-developed QA/QC plan, they provided rapid and accurate measurements at various test conditions.

\section{Subtask 2.4 Parametric Testing}

Once the preparations were completed, Alstom-PPL conducted the test campaign by first performing baseline mercury measurement for a week, followed by four weeks of parametric testing.

In order to obtain comprehensive data for go/no go decision, a test program was constructed as listed in Table 3.1-1. During the first week, uncontrolled mercury levels were established. The next week was dedicated to testing at a range of feed rates ( 0.5 to $5 \mathrm{lb} / \mathrm{MMacf}$ ) with Mer-Clean ${ }^{\mathrm{TM}}$ sorbents. The test conditions factored in variations in boiler load and flue gas flow, and selected conditions were repeated for data quality control and assurance.

During parametric testing for a given test condition, sorbent injection was performed over an 8-12 hour period, and the mercury concentrations from the unit allowed to recover for the subsequent 12 16 hours before the next test condition. The feed rates were varied to achieve several target removal efficiencies, e.9., 70\%, 90\%, and 95\% based on baseline mercury level.

Table 3.1-1 Summary of Short-Term Demonstration Plan

\begin{tabular}{|c|c|c|c|}
\hline Activity & Duration & $\begin{array}{c}\text { CMM } \\
\text { Measurements }\end{array}$ & $\begin{array}{c}\text { Coal and Ash } \\
\text { Sampling }\end{array}$ \\
\hline Baseline measurement & 1 week & AH inlet/stack & Daily \\
\hline Parametric Testing & 1 week & AH inlet/ESP outlet & Daily \\
\hline Ash Evaluation Testing & 2 weeks & AH inlet/ESP outlet & Daily \\
\hline
\end{tabular}

One of the objectives of LCRA's Fayette Unit \#3 testing was to determine the maximum level of mercury capture possible while still permitting continued ash sales. In order to achieve this, an injection rate was selected that allowed this, and then "ash evaluation" testing was conducted for 
the subsequent two weeks. Towards the end of the ash evaluation testing, a large quantity of ash from the ash silo was collected for detailed ash characterization testing by LCRA and their ash marketers.

$\mathrm{OH}$ measurements for mercury concentration and speciation were performed for selected conditions upstream of the sorbent injection location and at the ESP outlet to substantiate the mercury CMM data. A bulk quantity of by-product samples was also collected by plant personnel as directed by the Program Solicitation. Representative 5-gal bucket samples were taken from the ESP as well as from the scrubbers over the course of the test campaign. These were sent out to DOE contractors for byproduct characterization. Independent analysis was also carried out by Alstom-PPL and EERC for selected samples. The analysis of collected samples included mercury content, LOI, leachability and foam index tests. The plant operating data were obtained from the plant personnel. These included the temperature profile, oxygen concentration profile, $\mathrm{SO}_{2}, \mathrm{NO}_{x}$, and stack opacity at the exit of the ESP.

Throughout the testing, the test crew adhered to procedures that ensured tight QC and QA. The CMM system was calibrated before and after tests with zero and span drift checks and $\mathrm{OH}$ measurements were made for selected test conditions to ensure QA/QC.

\section{Task 4 Technology Transfer}

A number of utility companies have shown a great interest in the Mer-Cure ${ }^{\mathrm{TM}}$ mercury control technology because of its potential as a low capital and operating cost option for mercury control. In addition, under Mercury Round 2 it delivered high performance with respect to one of the most difficult configurations: low rank coals (PRB and lignite) with an ESP. Alstom-PPL disseminated project results to the power generation industry by attending and making presentations at Electric Power 2008 and A\&WMA's 2008 Mega Symposium. An accompanying technical paper was also written for publication at A\&WMA's 2008 Mega Symposium.

\section{Task 5 Project Management and Reporting}

Throughout the project, the project manager for Alstom-PPL communicated closely with DOE's program manager and other team members. Close contact was maintained with the DOE project manager to report any progresses or issues as well as to obtain feedback and overall direction. Quarterly progress reports were submitted as required under the solicitation. 


\section{Technology Description}

\subsection{Mer-Cure ${ }^{\mathrm{TM}}$ Process}

Alstom's Mer-Cure ${ }^{\mathrm{TM}}$ technology (Figure 4.1-1) employs a patented sorbent preparation and injection system that has several unique features to enhance its mercury control performance. First, sorbent injection is at an "ideal" temperature location (600-800 ${ }^{\circ} \mathrm{F}$ ), which allows contact with the elemental mercury to begin as early as it can be effective. Unlike more conventional AC injection systems, the Mer-Cure ${ }^{\mathrm{TM}}$ system injects the sorbent into the duct upstream of the air heater as shown in Figure 4.1-1. This enables maximum utilization of the entire effective temperature range for oxidation with the added sorbent. In current practice, carbon sorbents are often injected at low temperatures, such as downstream an air heater (typically between 250 and $350^{\circ} \mathrm{F}$ ), where oxidation kinetics are significantly slower. Also, the sorbent-mercury contact time becomes significantly shorter.

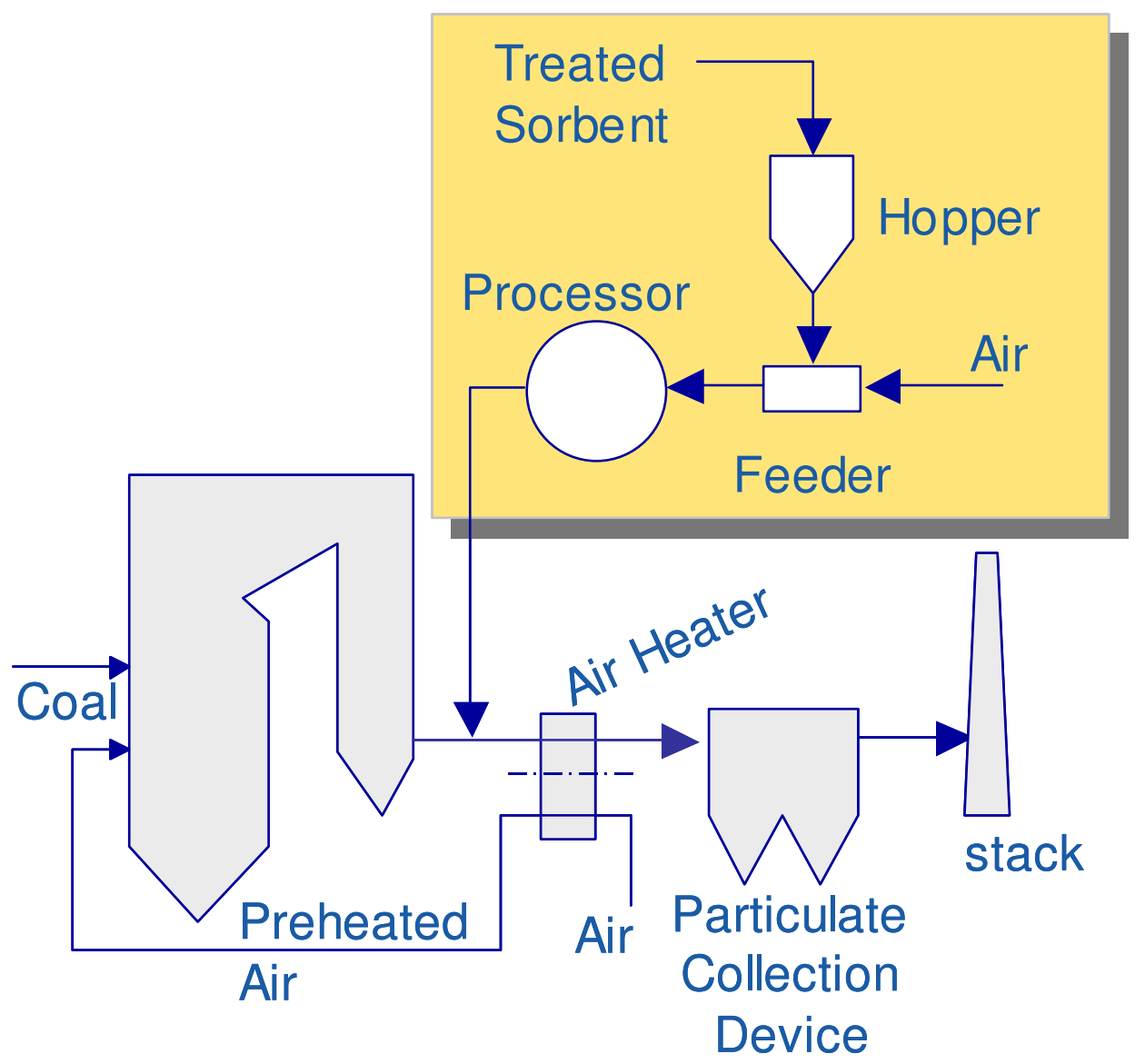

Figure 4.1-1 Alstom's Mer-Cure ${ }^{\mathrm{TM}}$ Technology for Mercury Capture

Second, the Mer-Cure ${ }^{\mathrm{TM}}$ system utilizes a carbon-based sorbent (called Mer-Clean ${ }^{\mathrm{TM}}$ ) with a proprietary additive that has been designed to accelerate mercury oxidation. Carefully designing the additive and its impregnation method to the sorbent ensures that Mer-Clean ${ }^{\mathrm{TM}}$ sorbent is active and retains its integrity throughout the temperature range. Additionally, Mer-Cure ${ }^{\mathrm{TM}}$ technology has been successfully applied to alternative commercially available sorbent products. 
A third distinct feature of Mer-Cure ${ }^{T M}$ is the unique injection methodology. The system is designed to remove any mass transfer limitations of mercury vapor to sorbent by de-agglomerating the sorbent into individual particles and uniformly distributing them to flue gas flow based on local flow conditions. CFD tools are employed to guide optimum design of the injection system, as sorbent distribution is critical to minimize its consumption for a given performance level.

\subsection{Mobile Mer-Cure ${ }^{\mathrm{TM}}$ Demonstration System}

As part of the Mercury Round 2 test program, Alstom designed and fabricated a mobile Mer-Cure ${ }^{\mathrm{TM}}$ system. The mobile Mer-Cure ${ }^{\mathrm{TM}}$ demonstration system (Figure 4.2-1) is composed of three components mounted on a 48-foot trailer: a sorbent storage system, a sorbent processing/delivery system, and a sorbent distribution system.

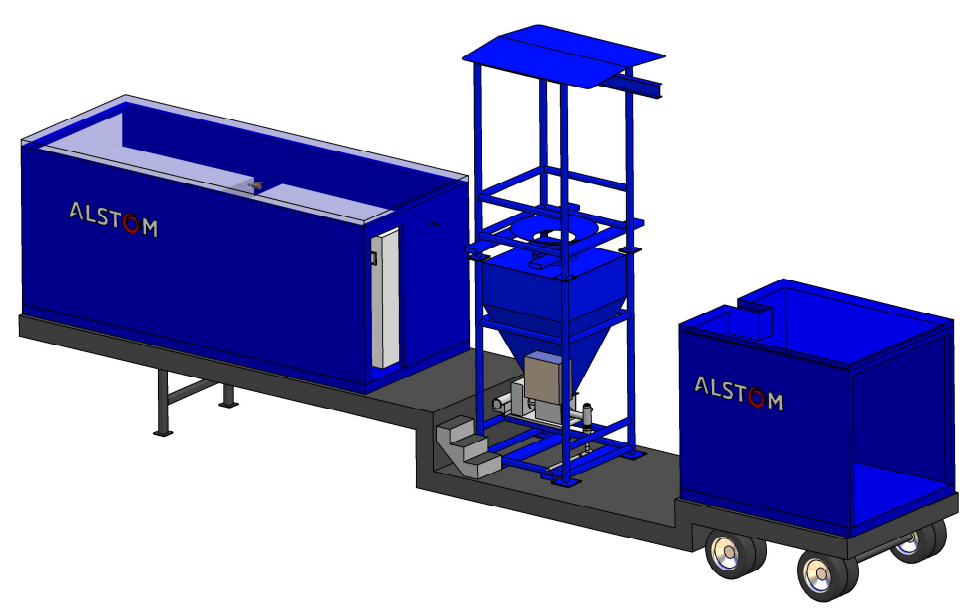

Figure 4.2-1 Mobile Mer-Cure ${ }^{\mathrm{TM}}$ Demonstration Trailer Schematic

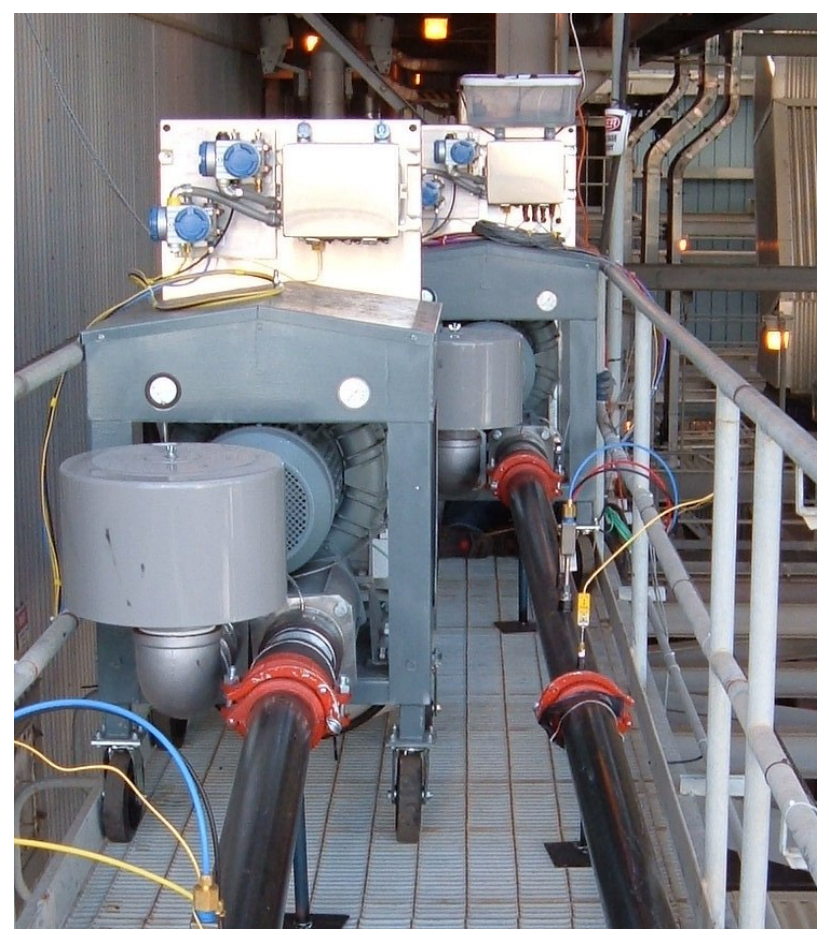

For this test program, this mobile unit has been redesigned for the Round 3 program to enable a longer-term demonstration at larger units. The two-month testing proposed at LCRA's Fayette Unit \#3 required treatment of the entire flue gas stream coming from a $480-\mathrm{MW}_{\mathrm{e}}$ boiler. This was accomplished by upgrading the transport air system. In preparation for the test campaign at LCRA, a blower system was employed in an effort to upgrade the transport air system for increased pneumatic capacity. The added blowers are shown in Figure 4.2-2. This allowed injection of sorbent into a larger volume of flue gas while not requiring any additional electrical services installed at the host sites.

\section{Figure 4.2-2 Mobile Mer-Cure ${ }^{\mathrm{TM}}$ System Upgraded Transport Air Blowers}

The sorbent storage system is a portable two-piece silo, which can be easily assembled and requires a relatively small footprint. The sorbent storage system, when assembled, is capable of loading powdered material of up to three 900-lb super-sack bags at the same time and will allow 
uninterrupted operation for 24 hours at a typical injection rate. Due to height limitations of the trailer during transportation, the storage system is delivered unassembled. The top piece of the twopiece storage system is attached to the base piece at the test site, as shown in Figure 4.2-3.

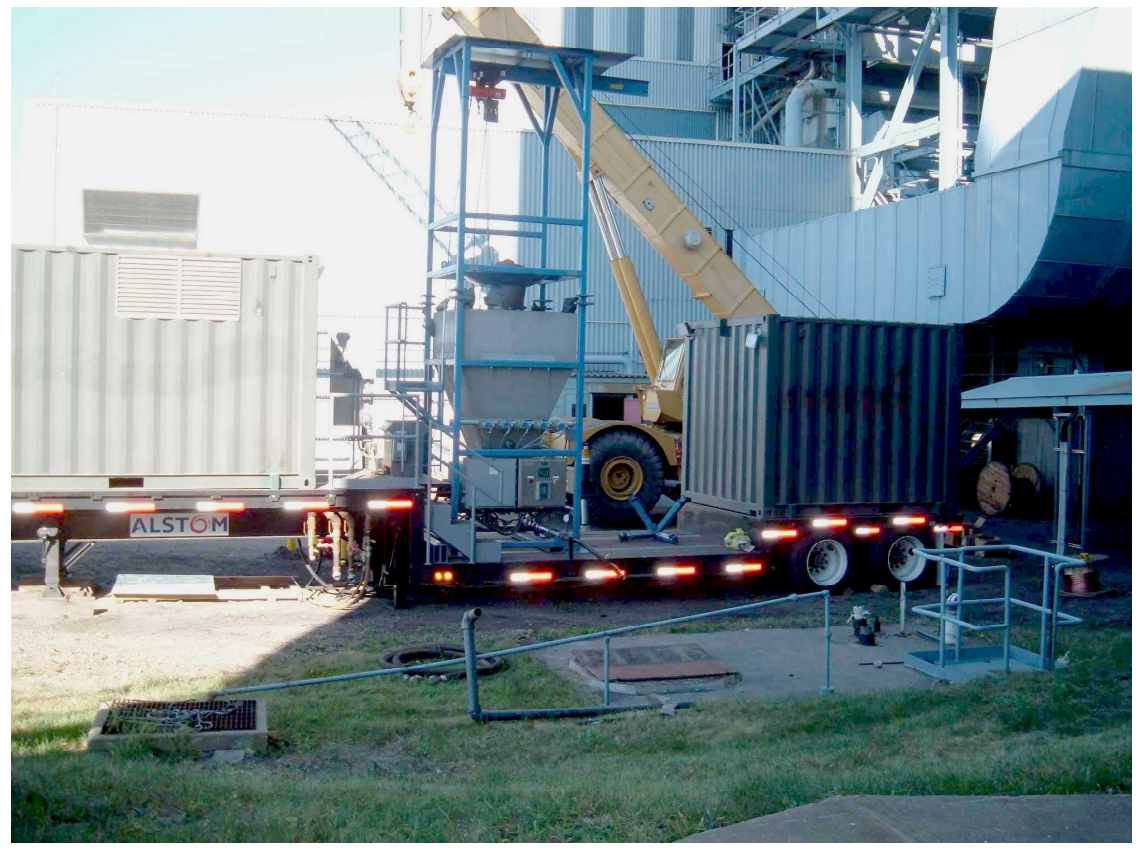

Figure 4.2-3 On Site Assembly of Mobile Mer-Cure ${ }^{\mathrm{TM}}$ Demonstration Trailer

The sorbent processing/delivery system consists of a variable screw feeder for metering the sorbent and an eductor for its pneumatic transport, a processor that de-agglomerates sorbent particles, and a compressed air system that supplies dry air for pneumatic transport. This system is mounted next to the storage system and is completely connected to the other subsystems.

The sorbent distribution system consists of flexible hoses, interconnecting pipes, distribution manifolds and injection lances. The injection lances designed based on CFD analysis of the duct flow conditions. They typically are $1 \frac{1}{4}$-inch pipes with multiple nozzles for even sorbent distribution throughout the duct cross-section.

The process equipment trailer is also equipped with control and data acquisition systems for the Mer-Cure ${ }^{\mathrm{TM}}$ system. The control system allows remote monitoring of operating conditions of the three Mer-Cure ${ }^{\mathrm{TM}}$ subsystems. It also automatically shuts down the system in case of a boiler trip or internal system failure. The control system is designed to receive load signals from the boiler and to vary sorbent injection rate as a function of boiler load. The data acquisition system stores system operating data such as injection rates, pressure levels of various sections of the sorbent delivery, processing and injections systems, and temperatures.

Appropriate distribution of sorbent into the flue gas stream is critical for maximum contact between the sorbent and the mercury in the flue gas stream. Flow modeling studies using Fluent CFD package were conducted using specific boiler design data to better determine the location and the number of injection lances. 
Based on calculated flow distributions, the number of injection ports, diameter and length of injection lances, and the number, orientation and size of injection lance nozzles were determined. The injection system was designed to proportionally distribute sorbent with flue gas volumetric flow.

The completed mobile Mer-Cure ${ }^{\mathrm{TM}}$ demonstration trailer and custom fabricated injection system was shipped to each site. The sorbent storage and delivery system was assembled at the site; the sorbent processing system was placed close to the sorbent injection system and was connected to the storage system by 4-inch flexible hoses. The sorbent distribution system was installed at the sorbent injection location and connected to the delivery system by 1.25 -inch flexible hoses. The mobile MerCure $^{T M}$ system is shown installed at the Fayette test site in Figure 4.2-4.

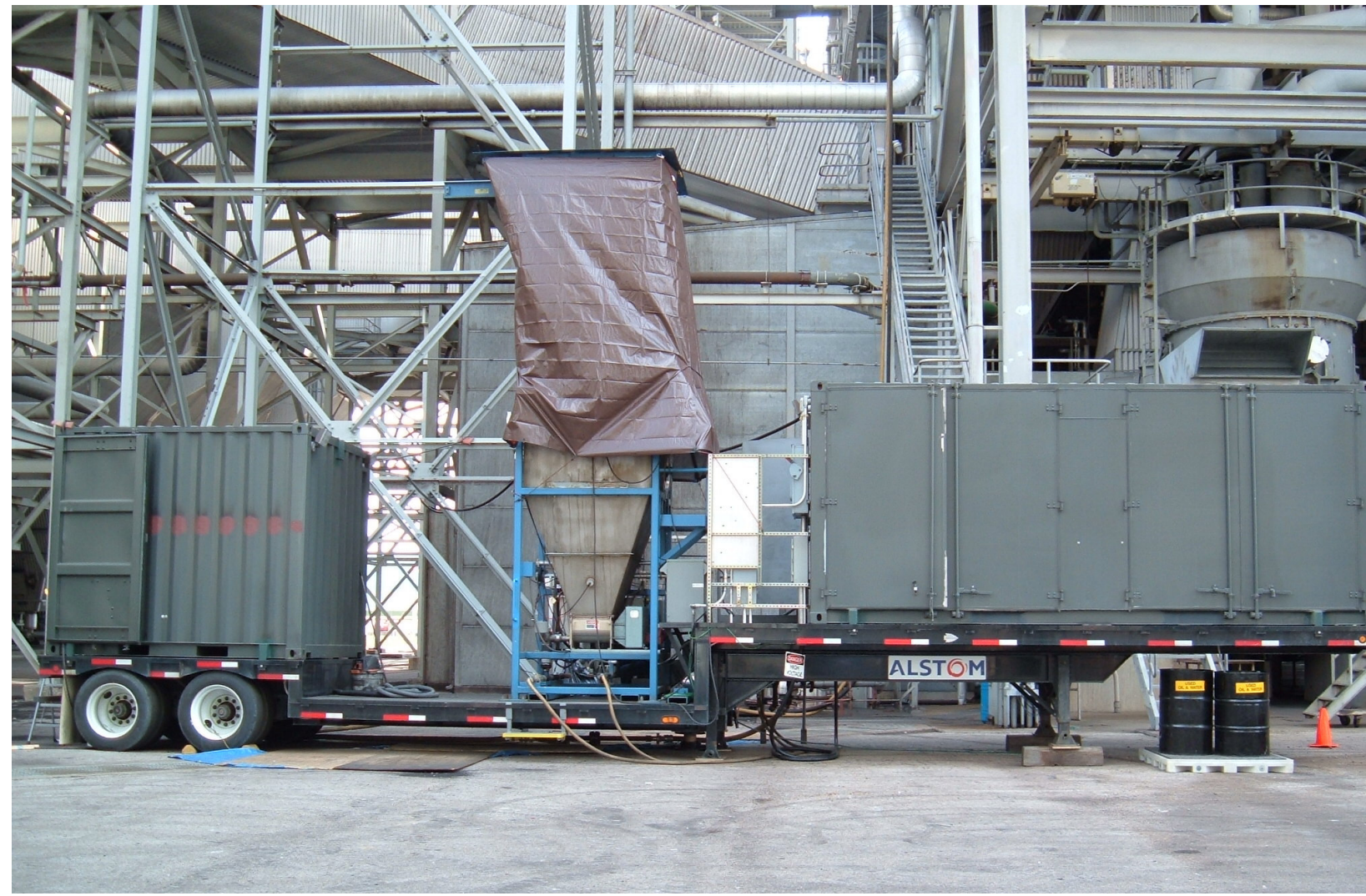

Figure 4.2-4 Moblie Mer-Cure ${ }^{\mathrm{TM}}$ Trailer Installed at Fayette Unit \#3 


\section{Test Planning and Mercury Instrumentation}

In general, the test program at each site consisted of three major components: baseline testing, parametric testing and long-term testing. During baseline testing, the existing mercury emissions were characterized for the unit, and the extent of native mercury capture was documented. During parametric testing, the sorbents to be evaluated were injected at a constant rate for 8-16 hours. For a given sorbent, several sorbent flow rates were tested to develop a parametric curve of sorbent injection rate versus mercury capture performance. For example, a sorbent could be injected for 12 hours each at $0.5,1.0,1.5$ and $2.0 \mathrm{lb} / \mathrm{MMacf}$ injection rate. That set of tests would constitute a parametric test run for a given sorbent. After roughly 12 hours without sorbent injection to allow the boiler to recover and return to its baseline condition, a parametric test run was performed on a second sorbent. Four different sorbent formulations were tested parametrically at Fayette Unit \#3. In addition to documenting $90 \%$ mercury capture, one of the objectives of LCRA's Fayette Unit \#3 testing was to determine the maximum level of mercury capture possible while still permitting continued ash sales. The two best performing sorbents from parametric testing were used for ash evaluation testing.

\subsection{Mercury Measurements}

Mercury concentrations in the flue gas (including speciation) were determined using CMMs and the $\mathrm{OH}$ method at (i) the air heater inlet, upstream of sorbent injection and (ii) the stack, downstream of the ESP (and wet scrubber, if present) after the particulate has been removed from the flue gas. The University of North Dakota - Energy and Environmental Research Center (UND-EERC) used PS Analytical and Tekran CMMs to perform the on-line mercury concentration measurements. In this set-up, the flue gas is sampled through an inertial separation probe (Figure 5.1-1) to remove any suspended particulate matter, before it is directed to a wet conditioning system and subsequently to a mercury analyzer.

The inertial separation probe enables a particle-free stream to be sampled from the dust-laden flue gas, while minimizing the contact of the flue gas with suspended particulate during the sampling process. This is particularly important at the inlet sampling location where a high concentration of ash is present compared to the stack where a relatively dust-free flue gas is present. Ash components and unburned carbon in the ash can modify the chemical speciation of mercury or adsorb mercury species during the sampling process upon intimate contact with the sampled gas. Such contact would occur, for example, when the sampled gas passes through a layer of ash collected on filters within the sampling system.

The mercury analyzer consists of a cold-vapor atomic adsorption spectrometer (CVAAS) coupled with a gold amalgamation system. The system is calibrated using vapor phase elemental mercury. The analyzers are capable of measuring both vapor-phase elemental and total mercury. The analyzer determines total vapor-phase mercury concentrations by reducing all of the oxidized mercury to the elemental form in the wet conditioning system. To measure elemental mercury, the oxidized mercury 
species are removed in the conditioning system, while the elemental mercury is not removed by the conditioning system.

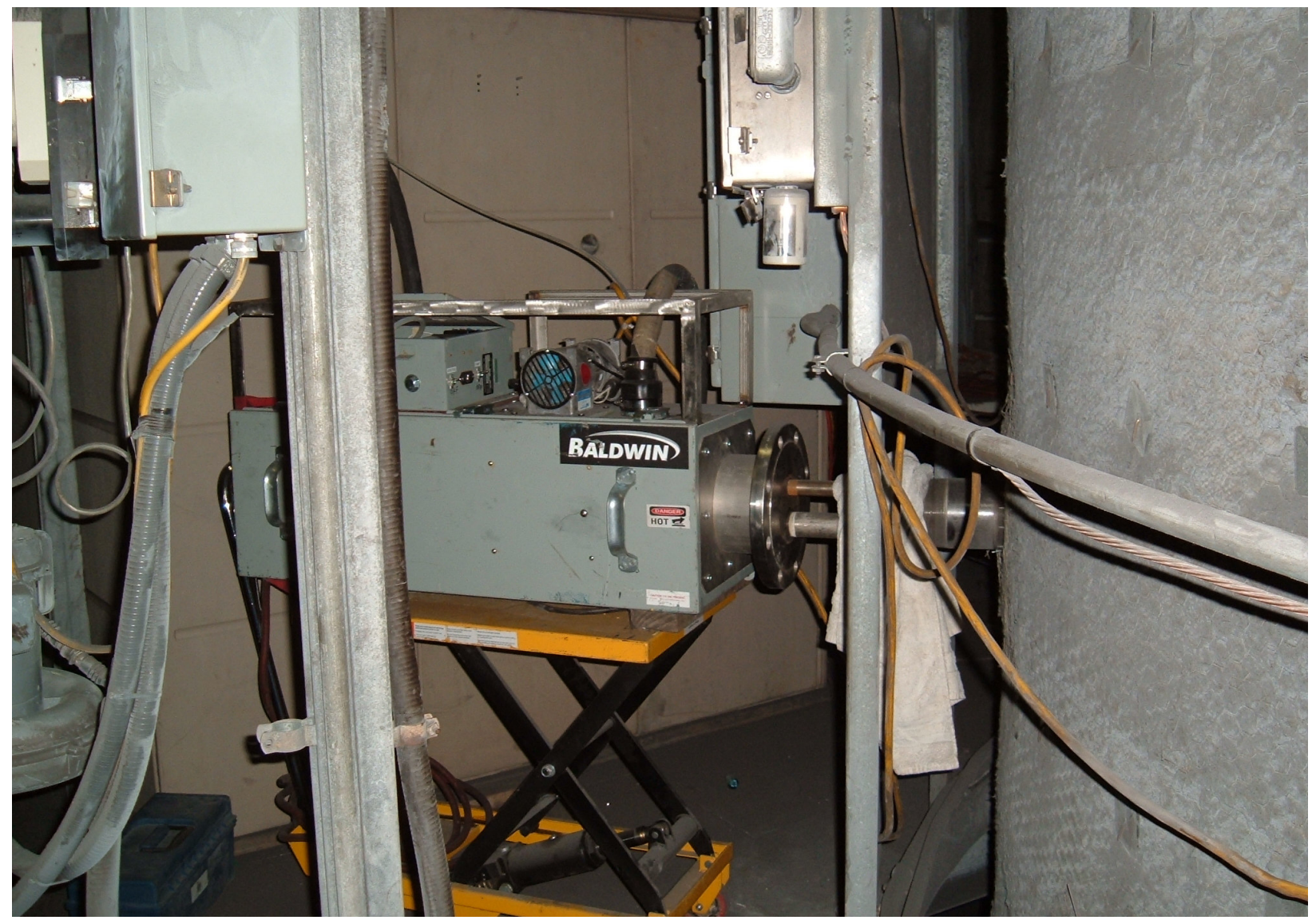

Figure 5.1-1 Inertial Separation Probe at Air Preheater inlet CMM Location

The results of the CMMs were validated by selective measurements using the $\mathrm{OH}$ method performed at the same location. With the $\mathrm{OH}$ method, flue gas is sampled through a filter (to capture particulate) and an impinger train that is designed to first capture oxidized mercury in the first three impingers (followed by a blank impinger) and then capture elemental mercury in the next three impingers (followed by a moisture removal impinger). A schematic of an $\mathrm{OH}$ sampling train is shown in Figure 5.1-2. Analysis of the filter and the impinger solutions provides speciated mercury concentration data. 


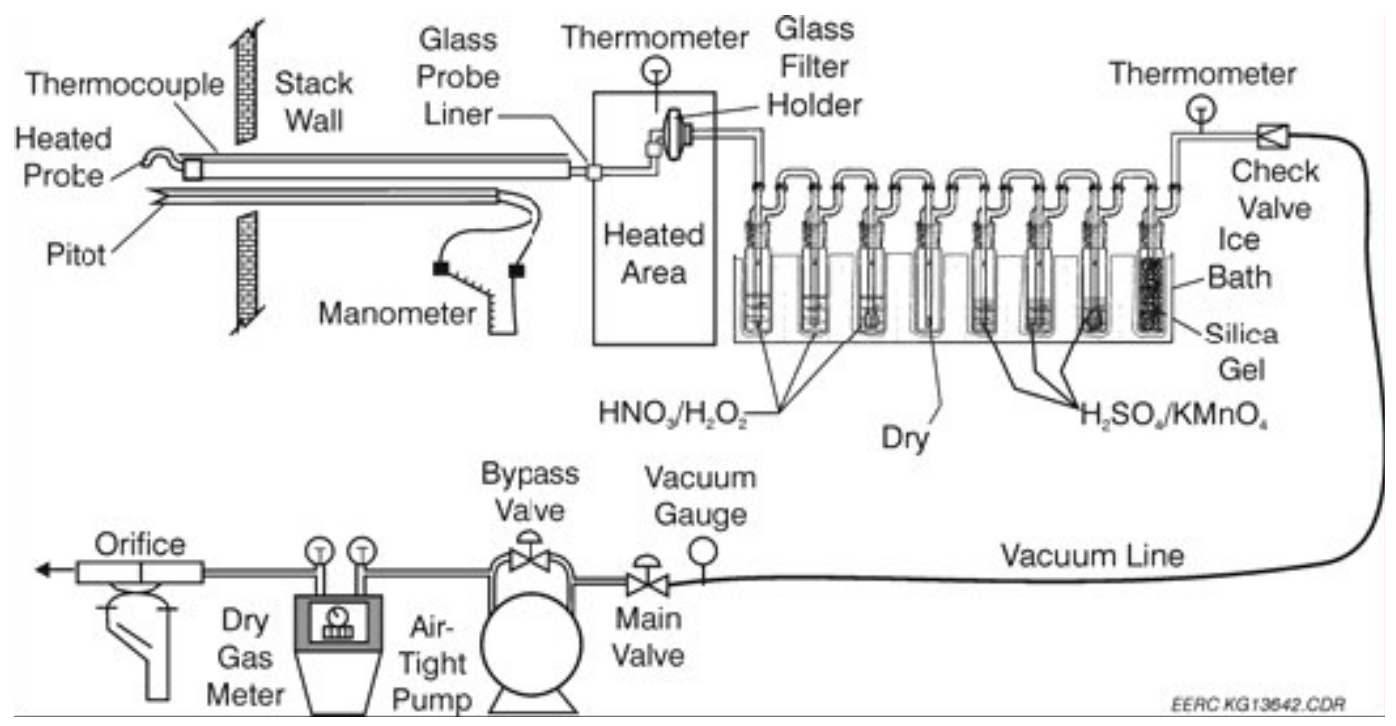

Figure 5.1-2 Ontario Hydro Sample Train Schematic

In addition to sampling for mercury concentrations using $\mathrm{CMM}$ and $\mathrm{OH}$ methods, samples of coal (from the feeders) and fly ash (from ESP hoppers) were obtained on a regular basis. The coal samples were analyzed for mercury and chlorine content in addition to obtaining their proximate and ultimate analysis. Ash samples were analyzed for unburned carbon content, and selected ash samples underwent foam index testing. Boiler operation data, including load, excess air, ESP operation and air heater outlet flue gas temperature were also collected throughout the test period. 


\section{Fayette Unit \#3 Demonstration Program}

This section gives a detailed summary of the field demonstration program Fayette Unit \#3 In addition to DOE/NETL's project goals under the original solicitation, another objective of LCRA for Fayette Unit \#3 testing was to determine the maximum level of mercury capture possible while still permitting continued ash sales.

\subsection{Site Description and Test Preparation}

LCRA's Fayette Unit \#3 is located in La Grange, TX, and fires PRB blends. The unit is a 480-MWe tangentially-fired, pulverized coal (PC) boiler and is equipped with low $\mathrm{NO}_{\mathrm{x}}$ burners, Ljungstrom ${ }^{\mathrm{TM}}$ air heaters, and two electrostatic precipitators (ESP), followed by a wet scrubber system with three modules. The ESP ash from the unit is currently sold to ash marketers. The specific collection area (SCA) of the ESP is $640 \mathrm{ft}^{2} / \mathrm{kacfm}$. Table 1.1-1 previously showed the unit configuration and coal and emissions data for Fayette Unit \#3.

Fayette Unit \#3 was chosen for this evaluation because it fires blends of PRB coal and is equipped with an ESP. Low rank coals such as lignite and PRB coals have been shown to be difficult to treat for mercury removal in past demonstration programs. ${ }^{1,2}$

A coal-fired boiler firing low rank coals with a cold-side ESP has emerged as a preferred combination in the US utility industry for several reasons. Utilities are switching to these lower sulfur Western coals to lower $\mathrm{SO}_{2}$ emissions. Second, when the boilers are operated in a low- $\mathrm{NO}_{x}$ configuration (air staging), very low emissions can be achieved with these coals (< $0.1 \mathrm{lb} / \mathrm{MMBtu})$, particularly with tangentially-fired boilers. Fuel cost, which is the predominant operating cost for coal-fired power plants, is also lower with the use of low rank coals. These coals are low cost because they are typically surface mined with low mining costs.

Previous tests at plants with PRB coal and a cold-side ESP using plain activated carbon sorbents indicated that the mercury removal was limited to about 70 percent. For example, in a Round 1 mercury control technology demonstration sponsored by US DOE, testing was conducted at We Energies Pleasant Prairie power plant, also a PRB-fired unit equipped with a cold-side ESP. The average mercury control efficiency ranged from 46 percent at an injection rate of $1.0 \mathrm{lb} / \mathrm{MMacf}$ to 50-55 percent at an injection rate of $5.0 \mathrm{lb} / \mathrm{MMacf}$. Increasing the injection rate to $10 \mathrm{lb} / \mathrm{MMacf}$ increased mercury capture across the ESP to 60-65 percent. Almost no further increase was observed at higher injection rates. ${ }^{1,2}$

In preparation for the design of the site-specific portion of the Mer-Cure ${ }^{\mathrm{TM}}$ system, site visits were made to Fayette Station. During the visits, more detailed information was collected such as that on the injection location (e.g., duct dimensions, turning vane arrangement), workspace, sampling port locations, trailer placement, equipment placement and the availability of utilities at work locations.

Extensive CFD studies were conducted to design the injection lances for the Mer-Cure ${ }^{\mathrm{TM}}$ system. The flue gas stream from Fayette Unit \#3 boiler is split into two streams (see Figure 6.1-5). Based on the calculated flue gas flow distributions, the numbers of injection ports, injection lances and their nozzles were determined. LCRA completed installation of the injection ports in late 2006. 
Appropriate distribution of sorbent into the flue gas stream is critical for maximum contact between the sorbent and the mercury in the flue gas stream. Flow modeling studies using the Fluent CFD package were conducted using specific boiler design data to better determine the location and the number of injection lances. Mer-Cure ${ }^{\mathrm{TM}}$ technology requires injection of sorbent into a location upstream air heaters. In order for maximum in-flight capture of mercury, the mixing characteristics of sorbent with flue gas at the boiler exit have been carefully examined by CFD.

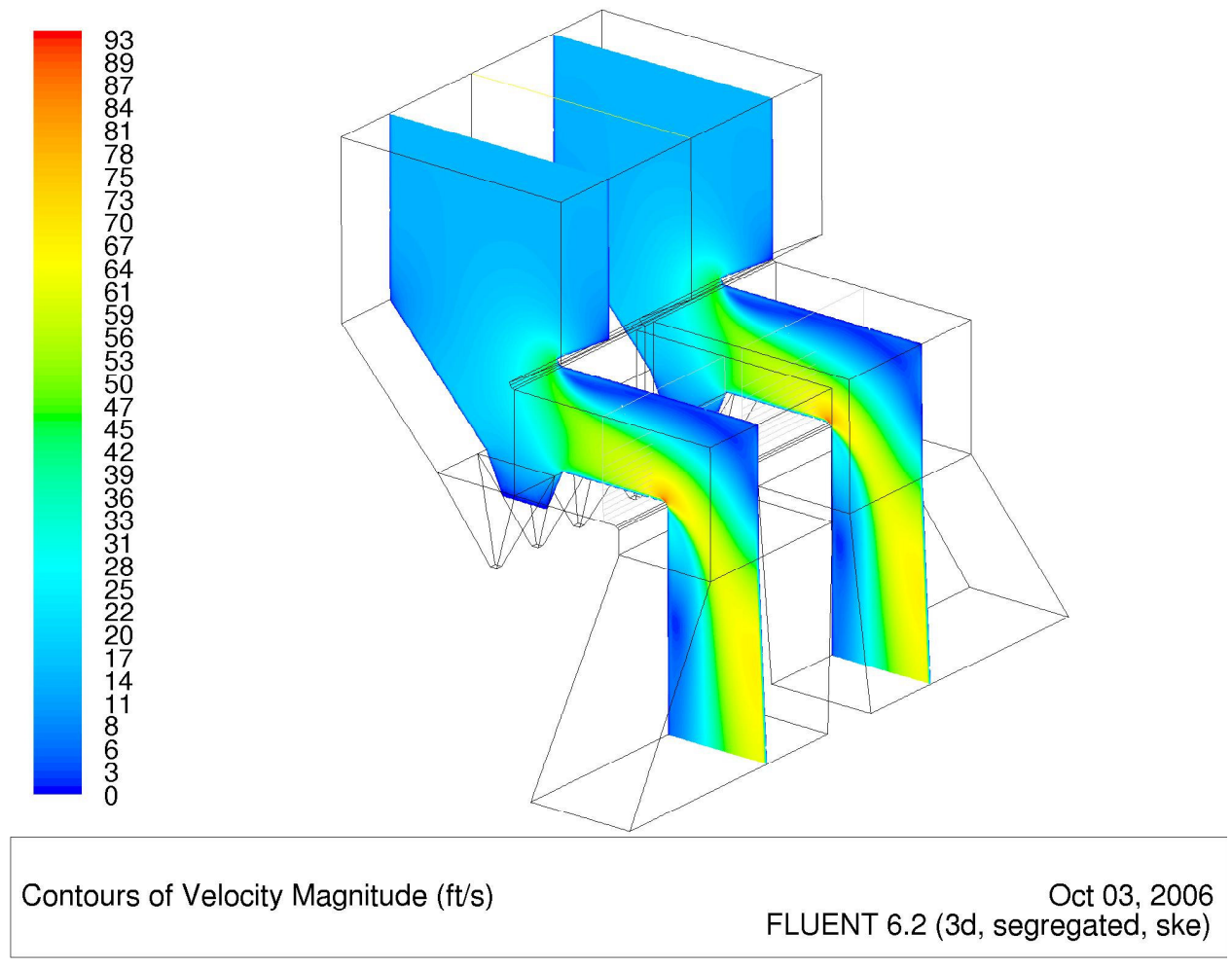

Figure 6.1-1 Flue Gas Flow Distribution at Fayette Unit \#3 Injection Location

As shown in Figure 6.1-1, the flue gas flow at Fayette Unit \#3 is concentrated more towards the floor of the horizontal section of the economizer outlet. A recirculation zone has been built at the top half of the section. This mal-distribution was been taken into account in designing the injection lances. More injection ports were placed at the bottom half of the injection lances, for example, so that the injected sorbent loading was uniform throughout the cross section of the flue gas ducts.

The CFD tool has also been used for other aspects of field testing preparation. Impact of installing and operating sorbent injection lances upstream of the $\mathrm{O}_{2}$ probes have been investigated, as shown in Figure 6.1-2. From the CFD work, it was concluded that transport air would not affect $\mathrm{O}_{2}$ readings by the existing probes.

Sampling locations were also identified using the tool. After evaluating various sampling options for the FGD geometry shown in Figure 6.1-3, the FGD outlet CMM was located at the stack. 


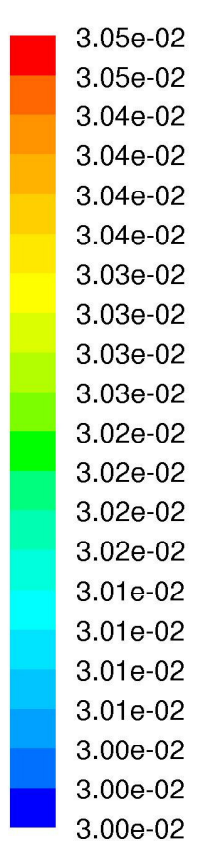

Contours of Mass fraction of 02
Nov 07, 2006

FLUENT 6.2 (3d, segregated, spe, ske)

Figure 6.1-2 02 Distribution at 02 Probe Location With Injection Lances in Operation
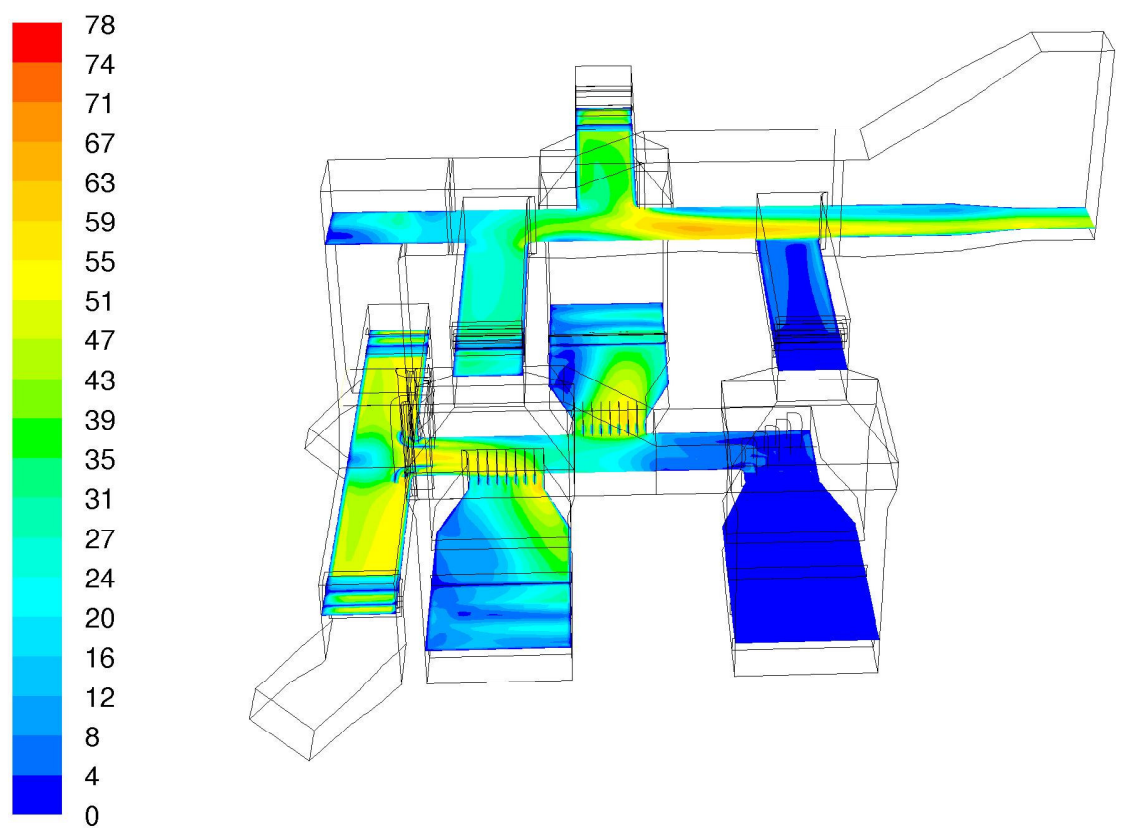

Contours of Velocity Magnitude (ft/s)

Nov 13,2006

FLUENT 6.2 (3d, segregated, spe, ske)

Figure 6.1-3 Flow Distribution around Fayette Unit \#3 FGD Modules 
Based on the CFD results and these flow distributions, a lance injection system was designed for Fayette Unit \#3 targeting proportional distribution of sorbent with the flue gas volumetric flow. The lance design parameters such as the number of lances, nozzle size, number and location for each of the lances were determined based on these studies to create immediate and uniform mixing of sorbent as it is introduced into the flue gas stream. Lances for the demonstration project were fabricated according to the final design.

The sorbent storage and delivery system was assembled at the site; the sorbent processing system was placed close to the sorbent injection system and was connected to the storage system by 4-inch flexible hoses. The sorbent injection and distribution systems are shown installed at the air heater inlet in Figure 6.1-4, and were connected to the sorbent delivery system by 4-inch flexible hoses. Shakedown of the assembled system was carried out when installation was complete.
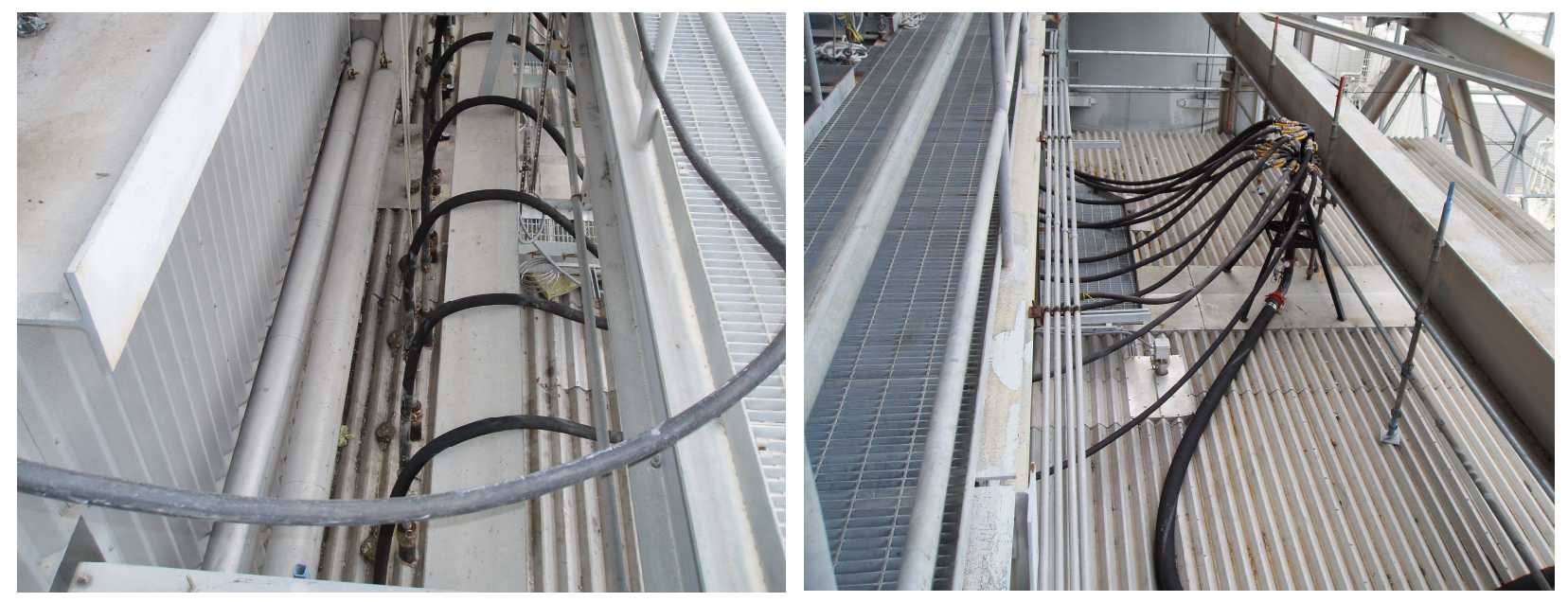

Figure 6.1-4 Fayette Unit \#3 Injection Lances and Distributor Installed at AH Inlet

Figure 6.1-5 shows a schematic diagram of the Fayette Unit \#3 layout and sampling locations for both gas and solids. As shown, the unit has two Ljungstrom ${ }^{\mathrm{TM}}$ air heaters in parallel. The particulate matter in the flue gas is collected by two ESPs downstream of the air heaters. The ash from the two ESPs is retrieved and collected in silo B by a pneumatic ash transfer system. The collected ash is currently sold for use in ready-mix concrete. Fayette Unit \#3 has three wet scrubber modules, two of which are in operation for $\mathrm{SO}_{2}$ control at any point in time. For flue gas temperature control, 15-25\% of the total flue gas flow bypasses the scrubber modules.

For the test campaign, three CMMs were installed by the EERC at the Fayette Unit \#3 plant: one upstream of the injection location (upstream of an air preheater), one upstream of the wet scrubber modules, and one at the stack. The CMMs were in operation throughout the program except the one upstream of the wet scrubber modules, which was on line only during the baseline test period. Coal samples were taken upstream of one of the eight (8) pulverizers on a daily basis. Fly ash samples were collected from various hoppers of the ESPs. Silo B ash was sampled every day. Wet scrubber samples were taken during baseline measurements. 


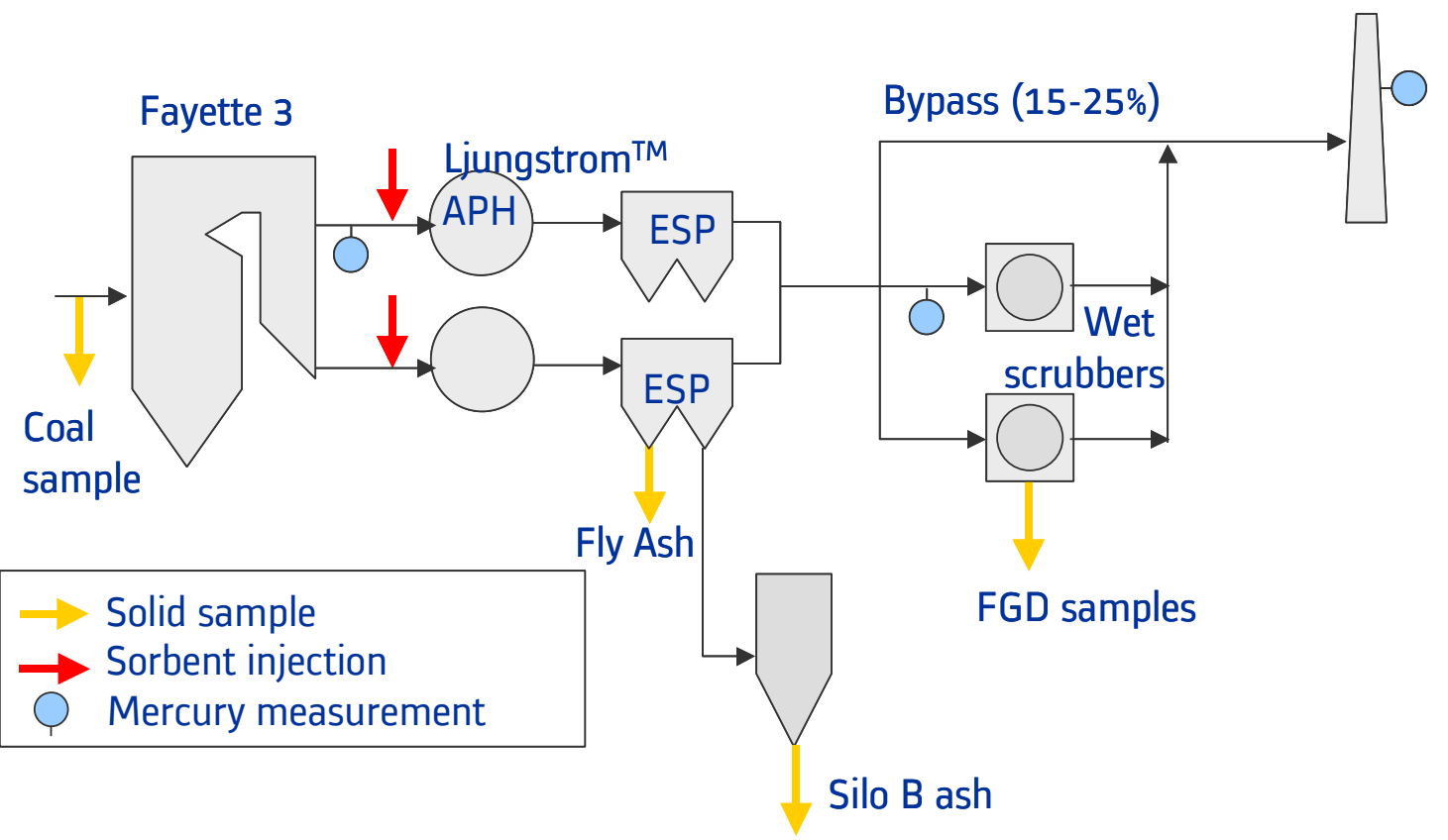

Figure 6.1-5 Sorbent Treatment and Sampling Locations, Fayette Unit \#3

One of the unique aspects of Alstom's Mer-Cure ${ }^{\mathrm{TM}}$ technology is that the sorbent injection is performed between the economizer and the air heater. In typical utility boilers, temperatures at this location are around 600 to $800^{\circ} \mathrm{F}$. The sorbents used in the Mer-Cure ${ }^{\mathrm{TM}}$ technology are activated carbon-based. Different halogenated components are added to the activated carbon and the material processed to make the final sorbent. An additional objective of LCRA for Fayette Unit \#3 testing was to determine the maximum level of mercury capture possible while still permitting continued ash sales. To determine the effect on ash properties, four sorbent formulations were tested (Mer-Clean ${ }^{\mathrm{TM}} 8$, eSorb ${ }^{\mathrm{TM}} 11$, eSorb $^{\mathrm{TM}} 13$ and eSorb ${ }^{\mathrm{TM}}$ 18). These formulations differed from each other in terms of the added components, amounts of the added components, and manufacturing process conditions.

Fayette Unit \#3 fires blends of PRB coals such as Black Thunder, Caballo, Jacobs Ranch, and others. Twenty-six (26) daily coal samples were collected during the test program, and Table 6.1-1 lists the average coal properties at Fayette Unit \#3 as determined by analysis of these samples. The average mercury content of the coal and its standard deviation were $0.075 \mu \mathrm{g} / \mathrm{g}$ dry coal and $0.010 \mu \mathrm{g} / \mathrm{g}$ dry coal, respectively. The average chlorine content of the coal was $105 \pm 11 \mathrm{ppm}$ on a dry basis.

The minimum and maximum mercury contents in the samples analyzed were $0.04 \mathrm{ppm}$ and 0.10 ppm, respectively, indicating a fairly wide variation in the quantity of mercury entering the boiler with the coal. 
Table 6.1-1 LCRA Fayette Unit \#3 Average Coal Properties

\begin{tabular}{|r|r|r|}
\hline Proximate analysis & As received & Dry basis \\
\hline Total moisture (\%) & 29.4 & $\mathrm{~N} / \mathrm{A}$ \\
\hline Volatile matter (\%) & 30.38 & 43.03 \\
\hline Fixed Carbon (\%) & 35.36 & 50.08 \\
\hline Ash (\%) & 4.86 & 6.88 \\
\hline HHV (Btu/lb) & 8,366 & 11,848 \\
\hline Ultimate analysis & As received & Dry basis \\
\hline Moisture (\%) & 29.4 & $\mathrm{~N} / \mathrm{A}$ \\
\hline Carbon (\%) & 48.39 & 68.54 \\
\hline Hydrogen (\%) & 3.37 & 18.31 \\
\hline Oxygen (\%) & 12.93 & 1.03 \\
\hline Nitrogen (\%) & 0.73 & 0.46 \\
\hline Sulfur (\%) & 0.32 & $105 \pm 11$ \\
\hline Chlorine (ppm) & $74 \pm 8$ & 6.88 \\
\hline Ash (\%) & 4.86 & 100.00 \\
\hline Total (\%) & 100.00 & $0.075 \pm 0.010$ \\
\hline Ng ( $\mu$ g/g dry coal) & $6.35 \pm 0.89$ & $6.35 \pm 0.89$ \\
\hline Hg (lb/TBtu) & & \\
\hline \hline
\end{tabular}

Table 6.1-2 lists the tasks carried out to complete the LCRA Fayette Unit \#3 test campaign and their associated timeline.

Table 6.1-2 LCRA Fayette Unit \#3 Test Campaign Timeline

\begin{tabular}{|c|c|}
\hline Tasks & Timeline \\
\hline Baseline Measurement & March 5-11, 2007 \\
\hline Parametric Testing & March 12-18, 2007 \\
\hline Ash Evaluation Testing & March 19-31, 2007 \\
\hline System Removal & April 9-12, 2007 \\
\hline
\end{tabular}

Baseline measurements of mercury concentration in the flue gas were performed at the air heater inlet (pre-sorbent injection) and precipitator outlet. Validation data using the $\mathrm{OH}$ method was also obtained for the baseline condition. Subsequent to the baseline testing, approximately seven days of parametric testing was conducted. Parametric tests included four enhanced activated carbon sorbents. From parametric tests results, Mer-Clean ${ }^{\mathrm{TM}} 8$ and eSorb ${ }^{\mathrm{TM}} 18$ were chosen for the ash evaluation testing.

\subsection{Baseline Testing Results}

Baseline CMM measurements of gaseous mercury were made at various locations. Figure 6.2-1 shows a comparison between the measured gaseous mercury at the air heater inlet and the gaseous 
mercury level calculated from mercury content in the fuel. The total mercury at the air heater inlet fluctuated between 8 and $16 \mu \mathrm{g} / \mathrm{m}^{3}$ (corrected to $3 \% \mathrm{O}_{2}$ ) and averaged $11.7 \mu \mathrm{g} / \mathrm{m}^{3}$, while the calculated values from the mercury content in the fuel fluctuated from $8.5 \mu \mathrm{g} / \mathrm{m}^{3}$ to $13.2 \mu \mathrm{g} / \mathrm{m}^{3}$. The two mercury concentrations generally agree with each other. The comparison suggests that the fluctuation of the mercury level at the air heater inlet is largely due to the variation of mercury content in the fuel. It also shows that there is no inherent mercury capture between boiler and air heater inlet.

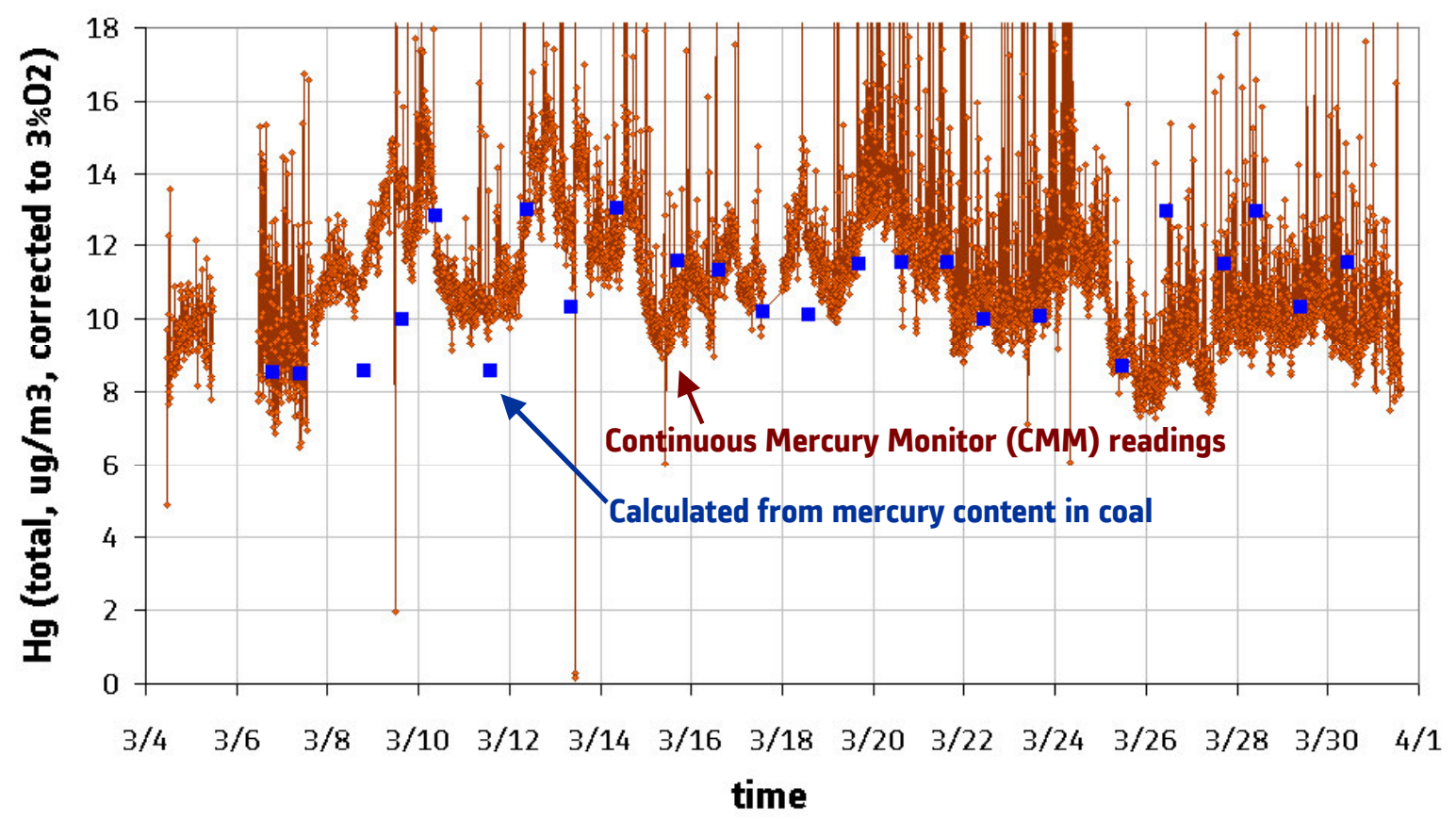

Figure 6.2-1 Comparison Between Coal Mercury Content and CMM Reading at AH Inlet

Figure 6.2-2 shows baseline CMM measurement results of gaseous mercury made at all three locations. The total mercury at the stack varied from 3 to $7 \mu \mathrm{g} / \mathrm{m}^{3}$ with an average of $5.9 \mu \mathrm{g} / \mathrm{m}^{3}$. The mercury level at the ESP outlet varied with time between those of the air heater inlet and stack and with an average of $8.5 \mu \mathrm{g} / \mathrm{m}^{3}$. Comparison of the mercury levels in Figure $6.2-2$ indicates that a significant amount of total mercury from the coal is captured across various air pollution control devices installed at Fayette Unit \#3. About $27 \%$ of the gaseous mercury is currently being removed between air heater inlet and ESP outlet, and another $23 \%$ of the air heater inlet gaseous mercury in removed across the wet scrubber modules.

Figure 6.2-3 shows mercury speciation data from CMM readings at the ESP outlet and at the stack. Elemental and oxidized mercury at the ESP outlet averaged 1.7 and $6.8 \mu \mathrm{g} / \mathrm{m}^{3}$, respectively. Nearly $80 \%$ of the total gaseous mercury was in oxidized form at the ESP outlet and before the wet scrubber modules. At the stack, elemental and oxidized mercury averaged 4.2 and $1.7 \mu \mathrm{g} / \mathrm{m}^{3}$, respectively. The increase in elemental mercury indicates significant reemission of elemental mercury by the FGD modules. 


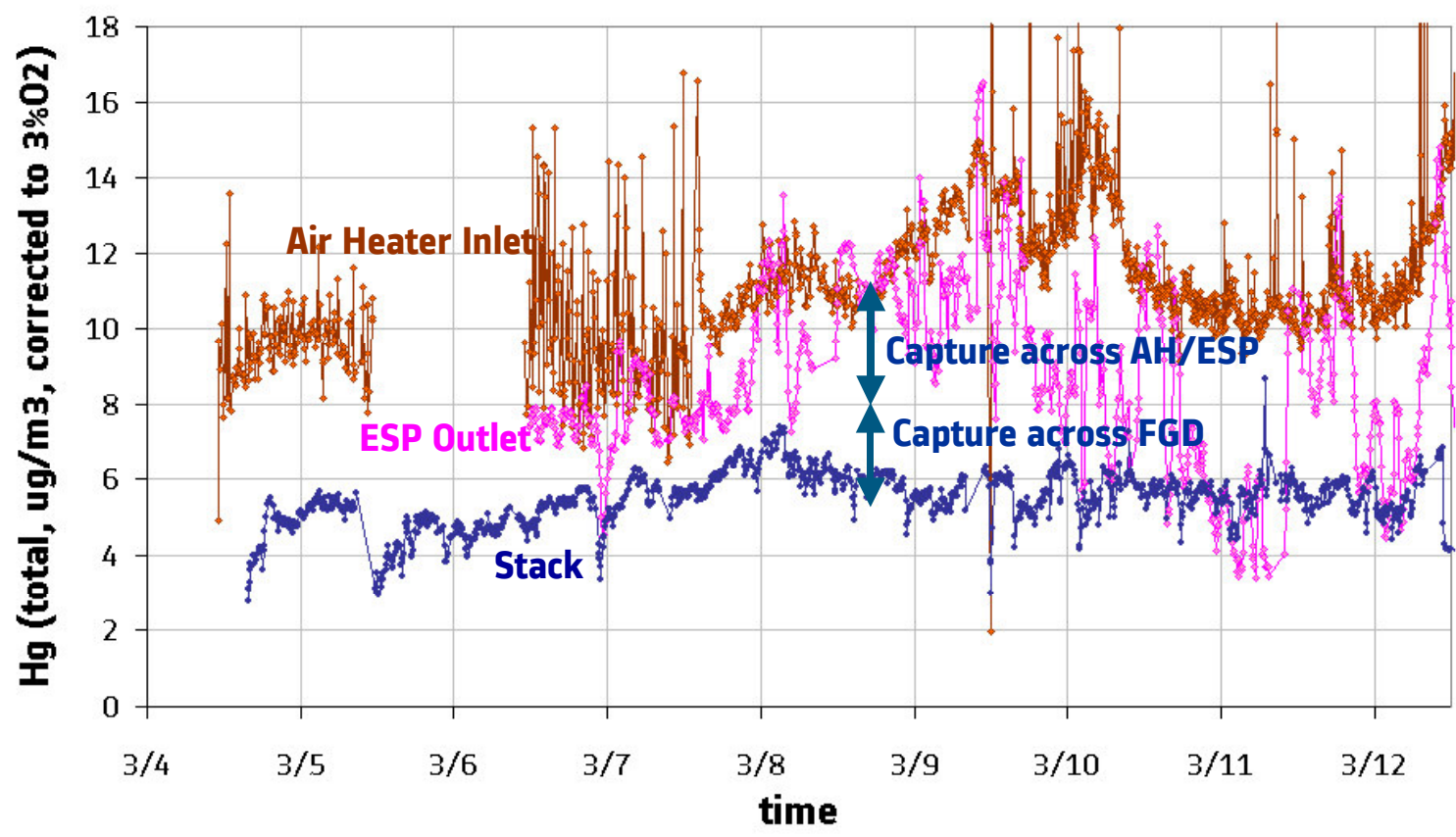

Figure 6.2-2 Baseline Total Mercury Readings from CMMs at Three Locations

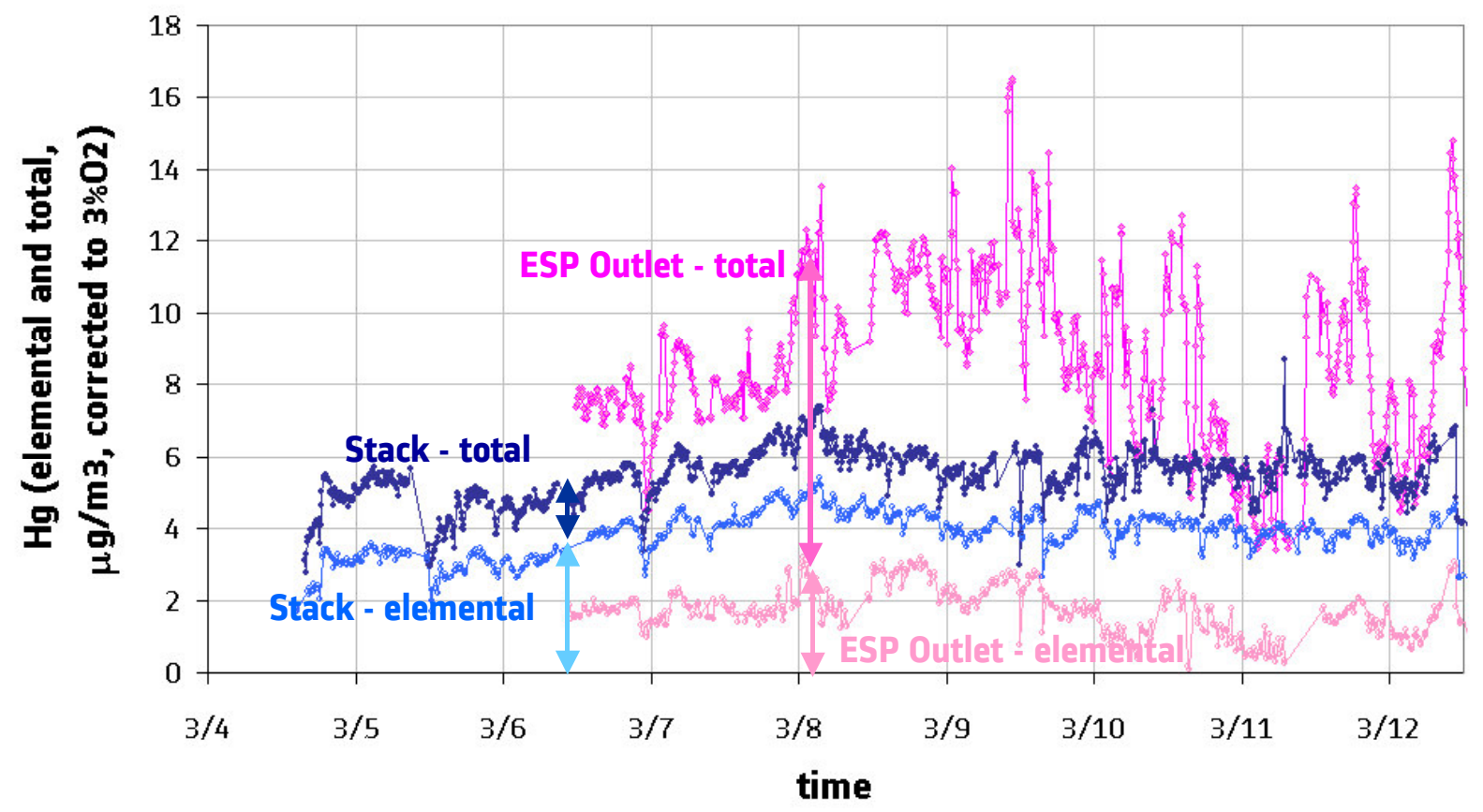

Figure 6.2-3 Mercury Speciation Data at the ESP outlet and Stack

Previous studies and field reports suggest that wet scrubbers capture most of the oxidized mercury, often called "co-benefit." The CMM data, however, does not indicate much co-benefit taking place at Fayette Unit \#3. The oxidized mercury at the ESP outlet is $6.8 \mu \mathrm{g} / \mathrm{m}^{3}$. If the scrubber modules captured all of the oxidized mercury at the ESP outlet, the expected stack mercury would be only the 
elemental portion of the total mercury at the ESP outlet, i.e., $1.7 \mu \mathrm{g} / \mathrm{m}^{3}$. The measured total mercury at the stack was $5.9 \mu \mathrm{g} / \mathrm{m}^{3}$, and the elemental mercury increased from 1.7 to $4.2 \mu \mathrm{g} / \mathrm{m}^{3}$ across the wet scrubber. The wet scrubber modules captured only $38 \%$ of the oxidized mercury entering the modules. Figure $6.2-3$ suggests that over $60 \%$ of the incoming oxidized mercury, in fact, has been reemitted as elemental mercury by the wet FGD modules.

\subsection{Parametric Testing Results}

Figure 8 shows a typical response of the mercury levels from Fayette Unit \#3 with Mer-Cure ${ }^{\mathrm{TM}}$ system sorbent injection during parametric testing. In this run, Mer-Clean ${ }^{\mathrm{TM}} 8$ was injected using the mobile Mer-Cure ${ }^{\mathrm{TM}}$ system at a concentration of $1.3 \mathrm{lb} / \mathrm{MMacf}$, which decreased the stack total mercury level from $5.9 \mu \mathrm{g} / \mathrm{m}^{3}$ to $0.36 \mu \mathrm{g} / \mathrm{m}^{3}$. Notice that by injecting the sorbent, the mercury level at the ESP outlet also decreased to approximately the same level as that for the stack. This clearly shows that all of the mercury capture as a result of sorbent injection took place between the injection point and the ESP outlet and that there was no additional capture of mercury across wet scrubber modules. The figure also shows the mercury reduction in two stages. Within an hour, the mercury level decreased from $8.5 \mathrm{~g} / \mathrm{m}^{3}$ to $3.5 \mu \mathrm{g} / \mathrm{m}^{3}$ (in flight capture) followed by a slow decrease to $0.5 \mu \mathrm{g} / \mathrm{m}^{3}$ over a 12 hour period (wall effects).

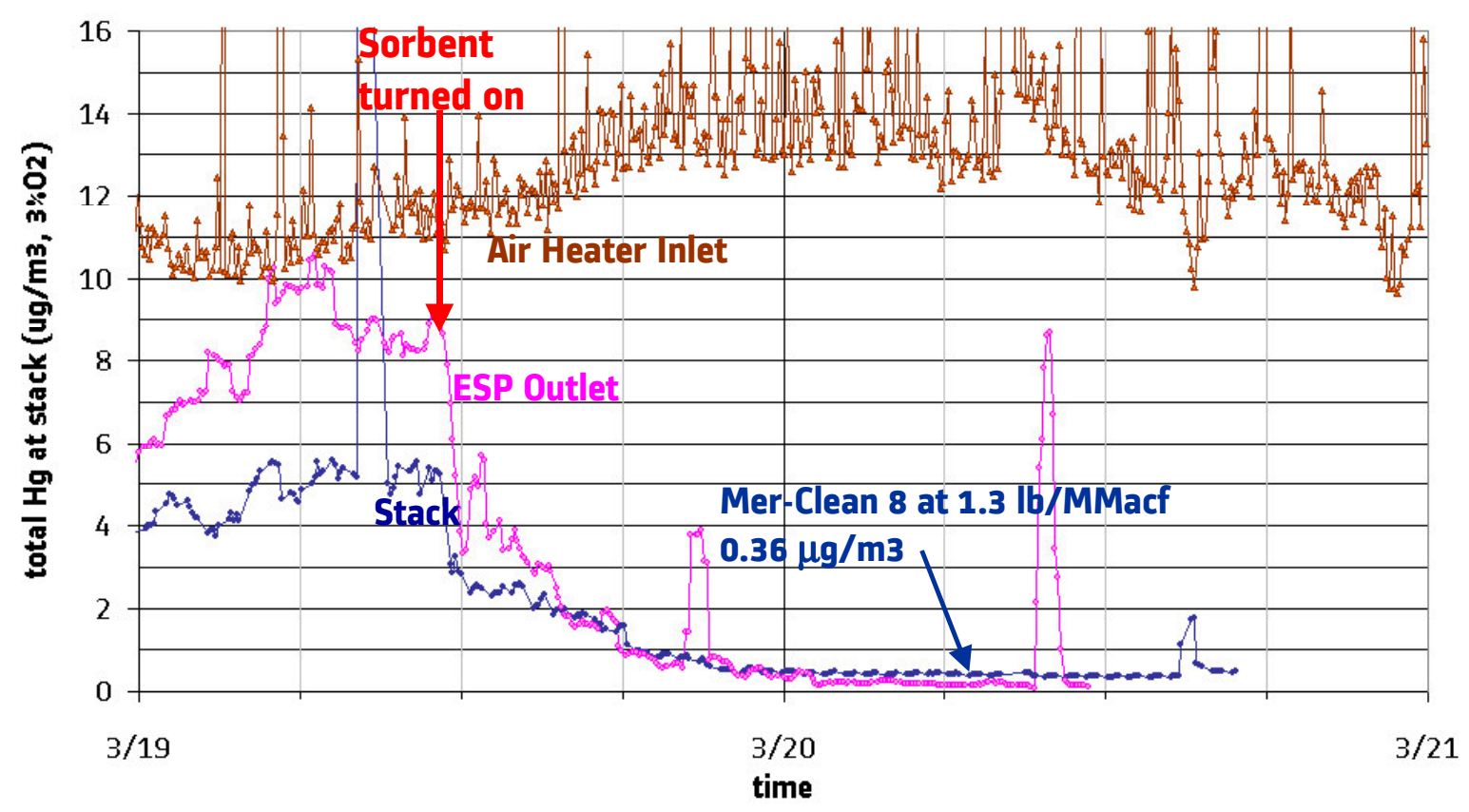

Figure 6.3-1 CMM Response to Mer-Cure ${ }^{\mathrm{TM}}$ Sorbent Injection at Fayette Unit \#3

Figure 6.3-2 shows the performance of Mer-Cure ${ }^{\mathrm{TM}}$ system at Fayette Unit \#3 during individual parametric test runs. The system was operated with four sorbents: Alstom's Mer-Clean ${ }^{\mathrm{TM}} 8$, and Envergex's eSorb ${ }^{T M} 11,13$ and 18 . In the figure, mercury removal efficiencies are reported for various sorbents as a function of sorbent injection rate in pounds per million actual cubic feet (lb/MMacf, where the "actual" condition refers to the FGD inlet conditions of $320^{\circ} \mathrm{F}, 7 \% \mathrm{O}_{2}$ ), as well 
as the percentage points of carbon increase in the ash due to sorbent injection. The removal efficiency has been calculated based on the uncontrolled stack concentrations of gaseous mercury measured during baseline testing. At $0.8 \mathrm{lb} / \mathrm{MMacf}$ sorbent injection rate, the system achieved $90 \%$ mercury reduction with a 0.25 percentage point increase in the fly ash carbon level.

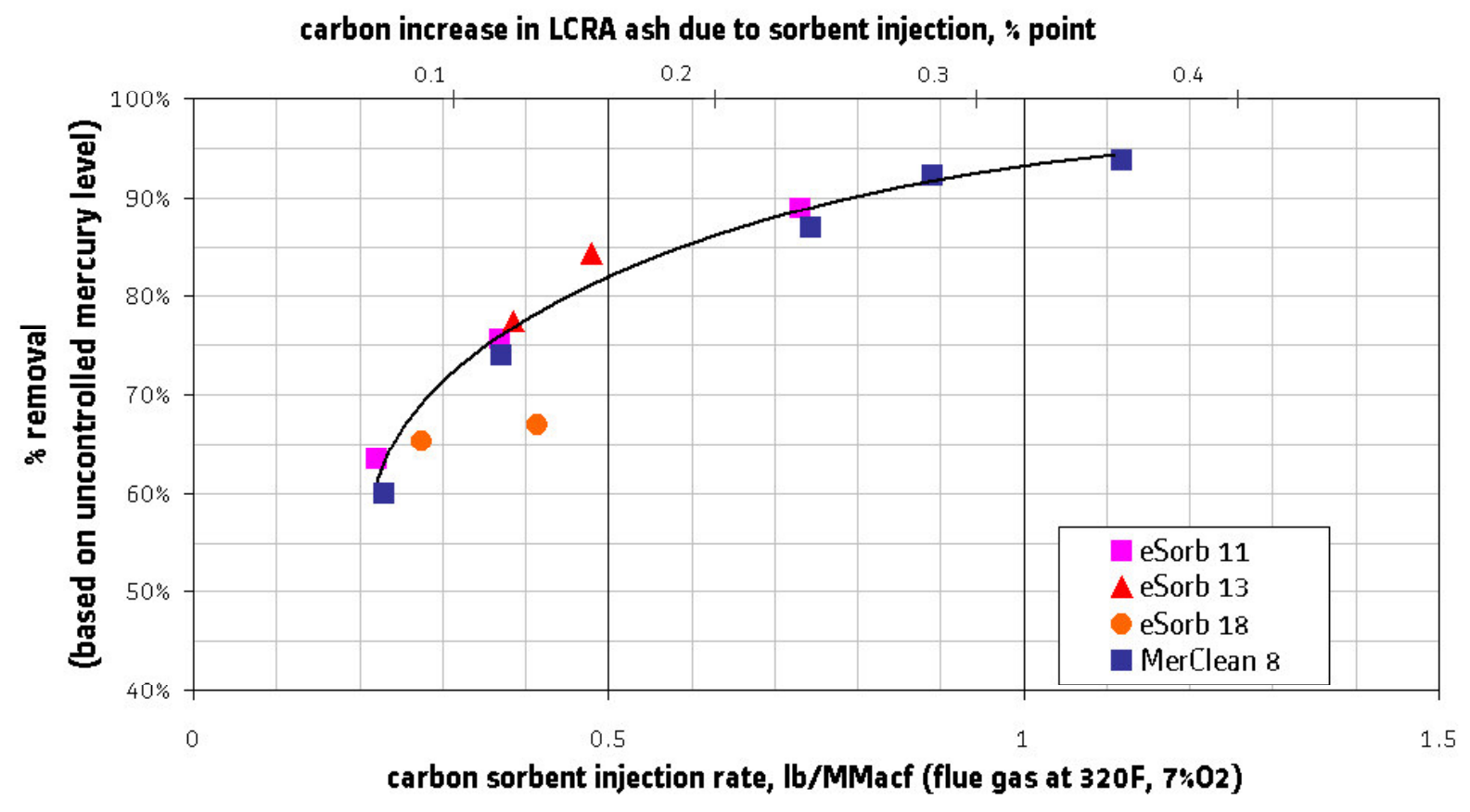

Figure 6.3-2 Parametric Test Results of Mer-Cure ${ }^{\mathrm{TM}}$ System at Fayette Unit \#3 (based on uncontrolled stack rate)

\subsection{Ash Evaluation Testing Results and Balance of Plant Impacts}

One of the objectives of the test program at Fayette Unit \#3 was to investigate ash salability with sorbent injection for mercury control. Fayette Unit \#3 currently sells ash for concrete applications. From the viewpoint of concrete applications, one of the most critical ash properties affected by sorbent injection is the adsorption characteristic of air entraining agent (AEA) by the ash. ${ }^{7}$

Previous studies by other researchers showed that even at a low rate, injection of activated carbonbased sorbent renders ash not salable. ${ }^{8,9}$ In order to evaluate ash salability, ash-sorbent mixtures of various proportions have been prepared and foam index-tested. The fly ash used for mixtures has been collected from the silo B (a silo dedicated to Fayette Unit \#3) during baseline measurement. The sorbent used to mix with the fly ash has been collected from one of the ports of the distributors. Mixtures were prepared to simulate silo ash that would be produced as a result of sorbent injection. MRT (Mineral Resource Technologies, Inc.), LCRA's ash marketer, conducted foam index tests according to their test procedure. MRT's test procedure determines the AEA adsorption tendency by adding drops of AEA solutions to ash samples in water until foam starts to cover the entire surface of the sample jar. The number of drops is then converted to a predefined foam index value.

Figure 6.4-1 shows such results from the foam index tests using the simulated ash-sorbent mixtures of various sorbents tested in the program. It also shows the threshold value of 312 above which ash 
may not be sold. The foam index value of the LCRA ash collected during baseline testing (no sorbent injection) is 156. As sorbent loading increases in the ash, the foam index increases in a linear fashion with the relative amount of carbon in the ash.

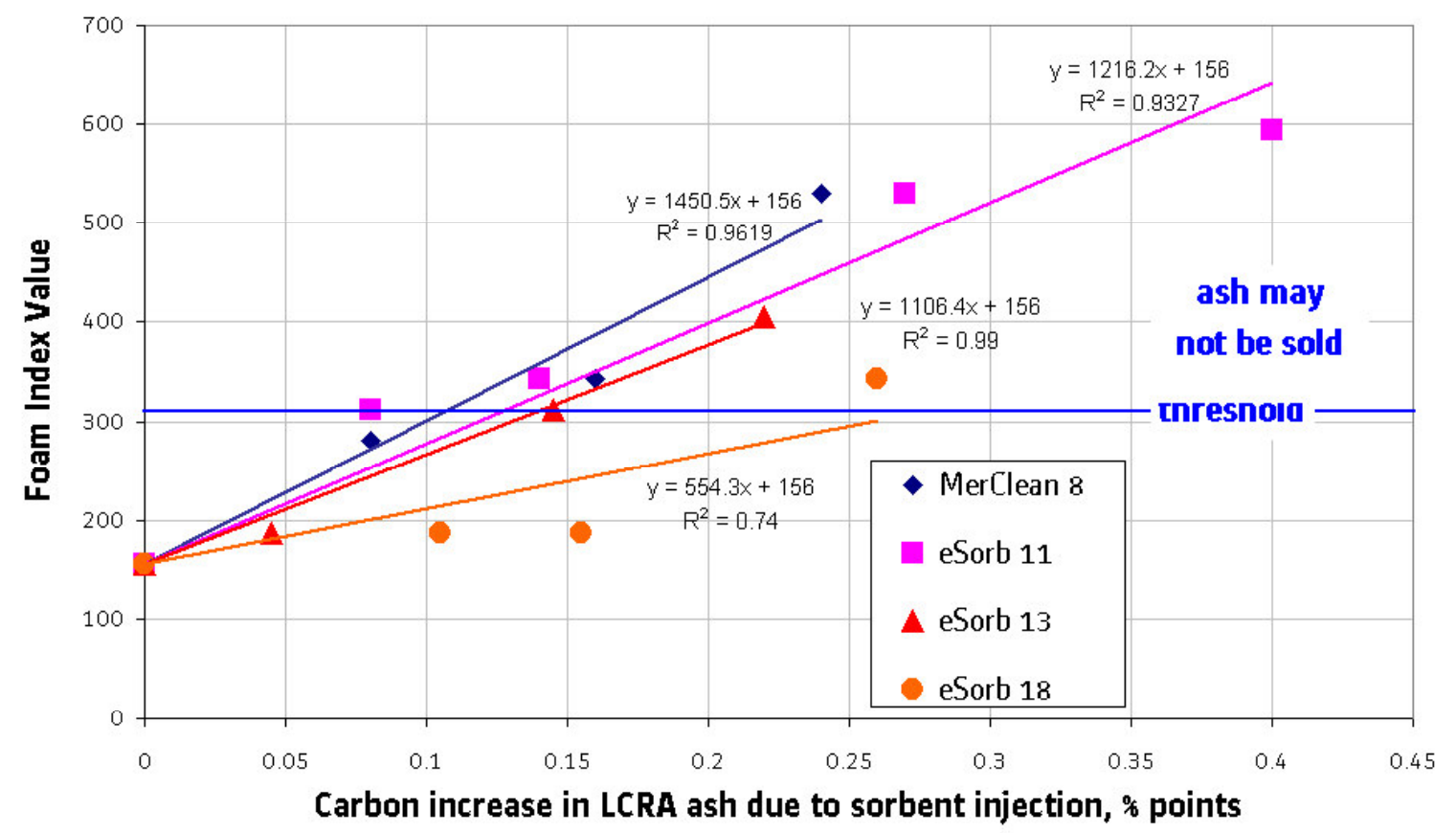

Figure 6.4-1 Foam Index Chart for LCRA Ash-sorbent Samples

Foam index test results show that Mer-Clean ${ }^{\mathrm{TM}} 8, \mathrm{eSorb}^{\mathrm{TM}} 11$ and eSorb ${ }^{\mathrm{TM}} 13$ sorbents performed similar to one another, with eSorb ${ }^{\mathrm{TM}} 18$ performing better than the other three. Data indicate that the maximum usage of the three similarly performing sorbents consistent with continued ash sale is a sorbent injection rate that results in a fly ash carbon increase of 0.10 to 0.15 percentage points.

Among the four sorbents foam index-tested, eSorb ${ }^{\top M} 18$ gave the lowest foam index values for a given amount of carbon increase. However, the eSorb ${ }^{\mathrm{TM}} 18$ sorbent did not perform as well as either the other two eSorb ${ }^{\mathrm{TM}}$ sorbents or the Mer-Clean ${ }^{\mathrm{TM}}$ sorbent during the limited number of mercury reduction parametric test runs with eSorb ${ }^{\mathrm{TM}} 18$ (Figure 6.3-2). Even though the eSorb ${ }^{\mathrm{TM}} 18$ was more "concrete-friendly", more of it would need to be injected to obtain the same mercury reduction results as the other three sorbents tested.

Figure 6.3-2 and Figure 6.4-1 can be used to evaluate the overall performance of sorbents for mercury reduction and ash quality combined. Figure 6.4-1 shows that Mer-Clean ${ }^{\mathrm{TM}} 8$ may be employed and injected using the Mer-Cure ${ }^{\mathrm{TM}}$ system until the incremental carbon in the ash increases by 0.1 percentage points. This corresponds to injection rate of approximately 0.4 $\mathrm{lb} / \mathrm{MMacf}$. At this injection rate, the current mercury emission is expected to decrease by $75 \%$. eSorb $^{T M} 13$ is more ash friendly and can be injected until the carbon in the ash increases by 0.15 percentage points. This corresponds to an $85 \%$ reduction in baseline mercury emissions.

Foam index tests were performed using simulated ash-sorbent mixtures to give a general idea of how a sorbent would impact the quality of the ash. In order to verify the findings, a weeklong 
continuous sorbent injection testing was carried out for each of the two sorbents. A third week of testing with a third sorbent was originally scheduled but had to be cancelled due to a forced outage towards the end of the test program. In this test period, sorbents were injected to achieve $90 \%$ reduction of the baseline mercury level. Ash samples were taken every day for ash evaluation.

Figure 6.4-2 shows the stack mercury level during Mer-Clean ${ }^{\mathrm{TM}} 8$ testing. As shown, the mercury level was maintained at $0.59 \mathrm{mg} / \mathrm{m3}$ (for a $90 \%$ reduction from baseline) by injecting Mer-Clean ${ }^{\mathrm{TM}} 8$ at about $0.9 \mathrm{lb} / \mathrm{MMacf}$, corresponding to an ash carbon increase of 0.28 percentage points. Bulk ash samples were taken every morning during the test week and analyzed for foaming tendency. The foam index values for those four days were $375,562,531$, and 562 , showing that after three days of continuous injection, representative bulk ash samples could be taken. The final value of 562 was very close to the value from the simulated ash mixture tests (Figure 6.4-1) but was higher than the threshold of 312 , potentially rendering the ash not salable for concrete application.

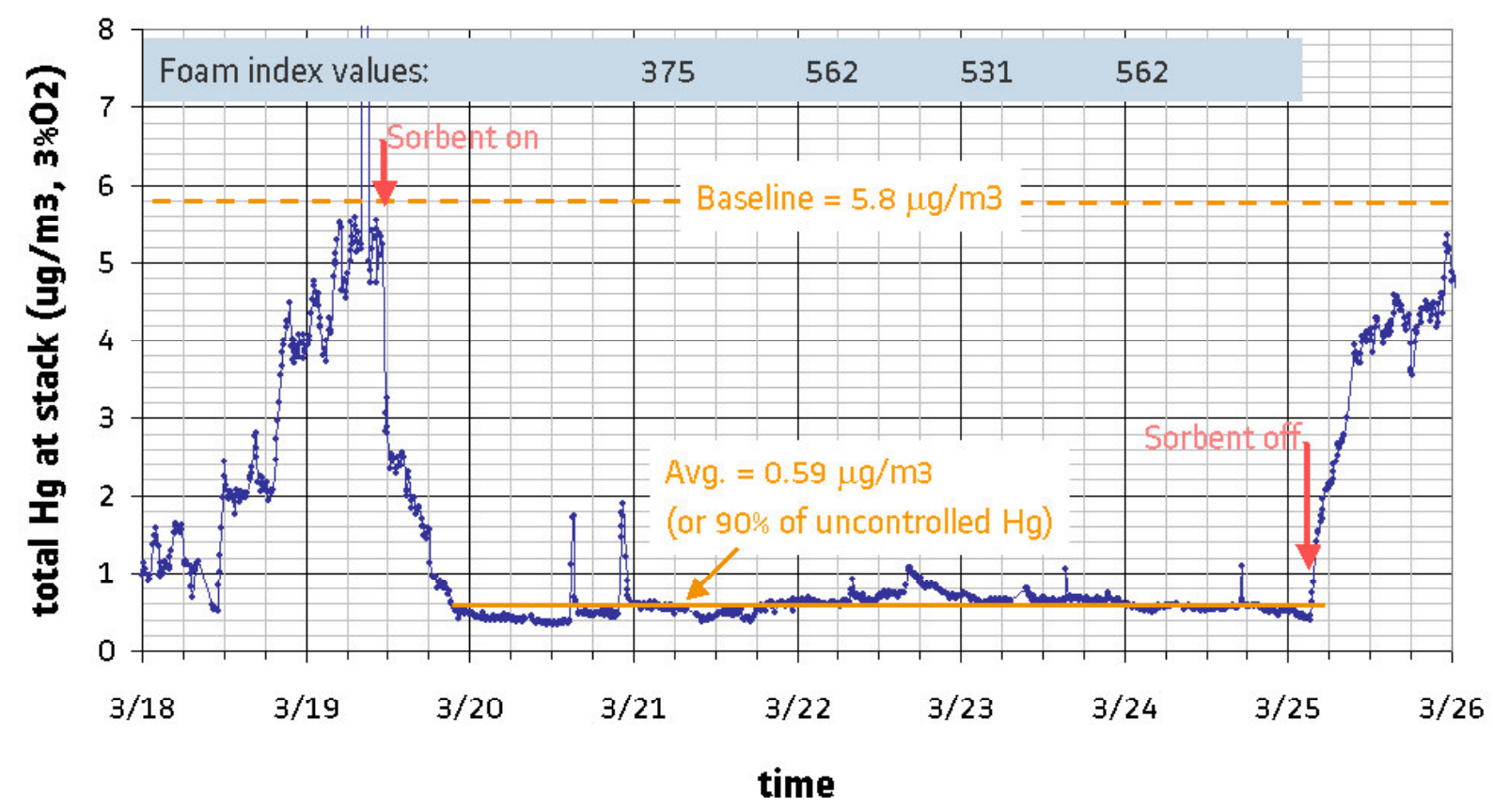

Figure 6.4-2 Continuous Injection of Mer-Clean ${ }^{\mathrm{TM}} 8$ Sorbent for Ash Evaluation

The subsequent week of ash evaluation testing was conducted with the second sorbent, eSorb ${ }^{\mathrm{TM}} 11$ from Envergex, LLC. It was also injected at about $0.9 \mathrm{lb} / \mathrm{MMacf}$, corresponding to an ash carbon increase of 0.28 percentage points, and again targeting $90 \%$ reduction of the baseline mercury at the stack. Figure 6.4-3 shows the stack mercury level during eSorb ${ }^{\mathrm{TM}} 11$ testing. The foam index value for the bulk ash sample taken towards the end of the test week was 470, again very close to the value from the simulated ash mixture tests (Figure 6.4-1). This value was also higher than the threshold value of 312 and again potentially renders the ash not salable for concrete application.

From the ash evaluation tests, it is clear that neither of the two sorbents tested can simultaneously achieve both $90 \%$ reduction of baseline mercury and ash salability requirements. As mentioned previously, the maximum baseline mercury reduction achievable was $75 \%$ for Mer-Clean ${ }^{\mathrm{TM}} 8$ and $85 \%$ 


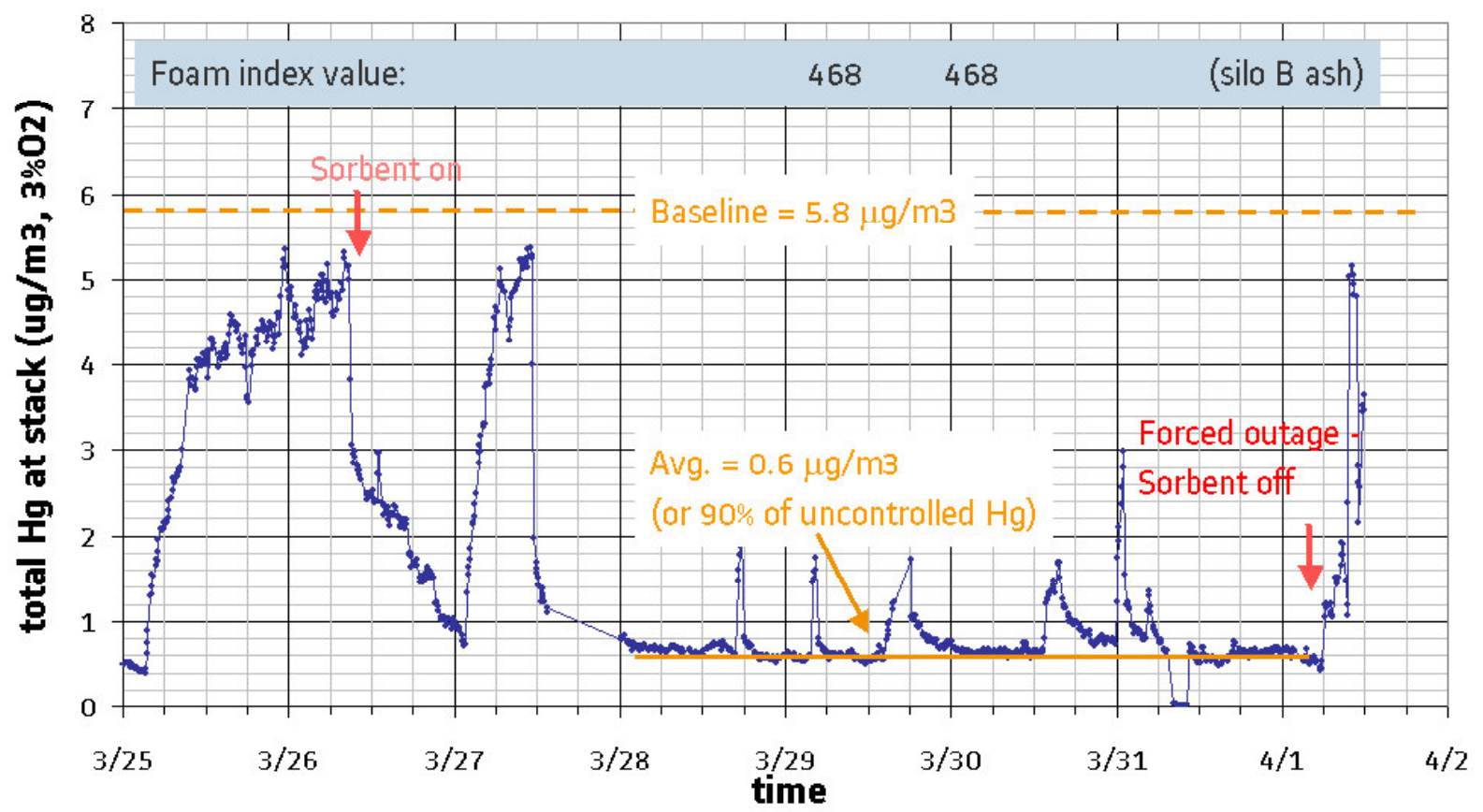

Figure 6.4-3 Continuous Injection of eSorb ${ }^{\mathrm{TM}} 11$ Sorbent for Ash Evaluation

for eSorb ${ }^{\mathrm{TM}} 13$. In terms of percentage removal based on the coal input mercury, this performance translates to an $88 \%$ and $92 \%$ reduction, respectively, as shown in Figure $6.4-4$.

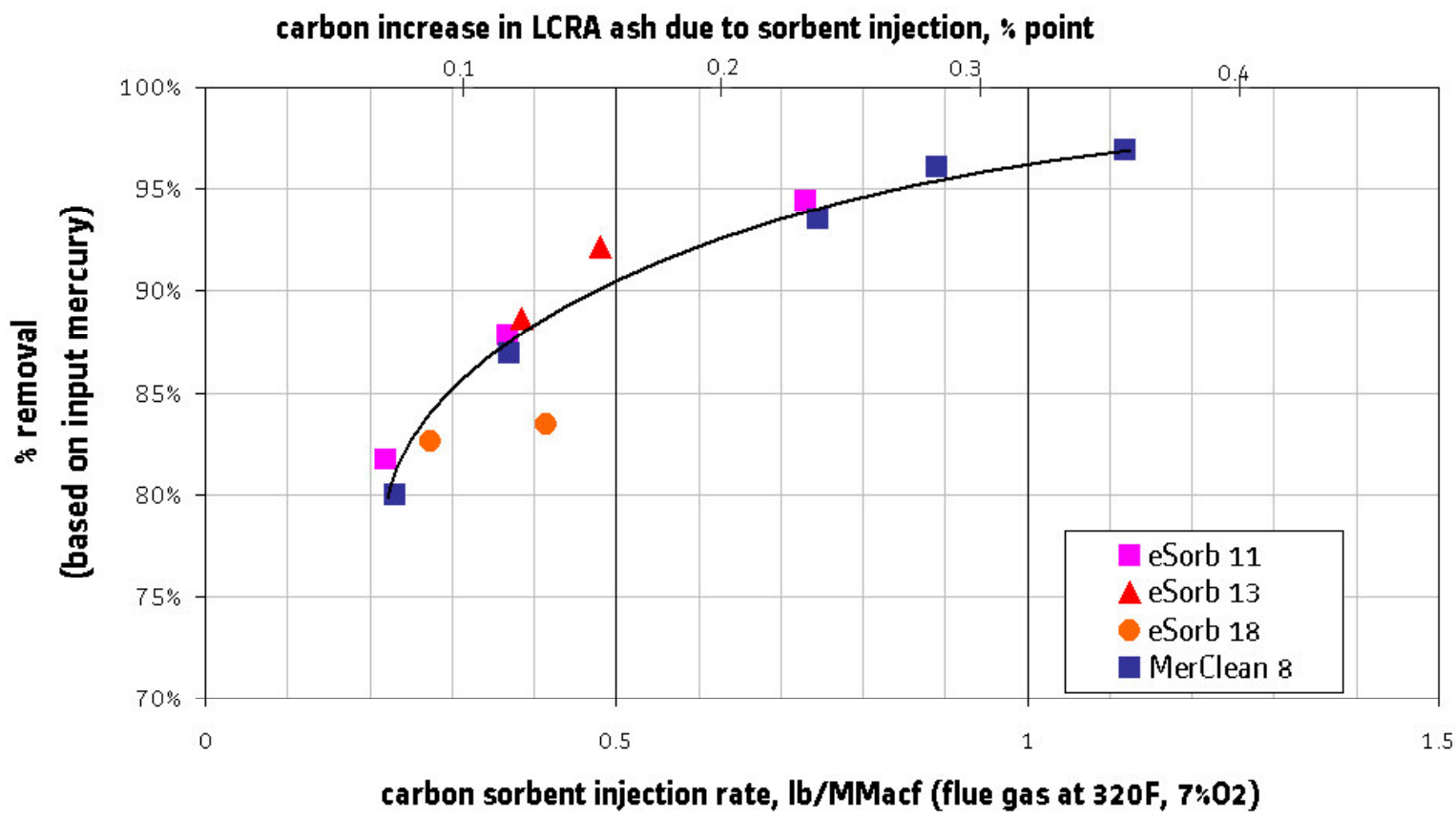

Figure 6.4-4 Parametric Test Results of Mer-Cure ${ }^{\mathrm{TM}}$ System at Fayette Unit \#3 (based on coal mercury content) 
The performance data presented demonstrates that Mer-Cure ${ }^{T M}$ technology offers a solution to effectively control mercury emissions from coal-fired boilers. Sorbent injection may be of operational concern to boiler operators. In this section, the impact of sorbent injection on ash leaching properties and on opacity is discussed.

The ash samples from ash evaluation period have been tested for leaching. The TCLP extraction test results are listed in Table 6.4-1. As listed, no detectable mercury has been leached out. Previous studies have also shown that mercury captured on activated carbon has very low leachability. ${ }^{10,11}$

Table 6.4-1 LCRA Fayette Unit \#3 Ash Leaching Test Results

\begin{tabular}{|c|c|c|c|c|c|c|c|c|c|c|c|}
\hline \multirow{2}{*}{$\begin{array}{l}\text { Sample } \\
\text { location }\end{array}$} & \multirow[t]{2}{*}{ Date } & \multirow[t]{2}{*}{ Time } & \multirow{2}{*}{$\begin{array}{l}\mu g \\
\mathrm{Hg} / \mathrm{l}\end{array}$} & \multicolumn{8}{|c|}{ TCLP Extraction (mg/liter) } \\
\hline & & & & As & $\mathrm{Ba}$ & $\mathrm{Cd}$ & $\mathrm{Cr}$ & $\mathrm{Pb}$ & $\mathrm{Hg}$ & Se & $\mathrm{Ag}$ \\
\hline $\begin{array}{l}\text { Reclaim } \\
\text { pond }\end{array}$ & $3 / 12$ & $8: 57$ & $<0.2$ & & & & & & & & \\
\hline $\begin{array}{l}\text { LS slurry } \\
\text { tank }\end{array}$ & $3 / 12$ & $8: 28$ & $<5$ & & & & & & & & \\
\hline Silo ash & $3 / 13$ & & & $<1$ & 3.5 & $<0.1$ & 0.3 & $<0.5$ & $<0.001$ & $<0.5$ & $<0.1$ \\
\hline Silo 3B-01 & $3 / 23$ & $17: 15$ & & $<1$ & 3.3 & $<0.1$ & 0.29 & $<0.5$ & $<0.001$ & $<0.5$ & $<0.1$ \\
\hline Silo 3B-02 & $3 / 23$ & $17: 15$ & & $<1$ & 2.9 & $<0.1$ & 0.28 & $<0.5$ & $<0.001$ & $<0.5$ & $<0.1$ \\
\hline Silo 3B-01 & $3 / 30$ & $16: 15$ & & $<1$ & 4.3 & $<0.1$ & 0.32 & $<0.5$ & $<0.001$ & $<0.5$ & $<0.1$ \\
\hline Silo 3B-02 & $3 / 30$ & $16: 15$ & & $<1$ & 3.6 & $<0.1$ & 0.28 & $<0.5$ & $<0.001$ & $<0.5$ & $<0.1$ \\
\hline Silo B & $3 / 28$ & $15: 05$ & & $<1$ & 3.7 & $<0.1$ & 0.31 & $<0.5$ & $<0.001$ & $<0.5$ & $<0.1$ \\
\hline Silo B & $3 / 29$ & $11: 35$ & & $<1$ & 3.6 & $<0.1$ & 0.32 & $<0.5$ & $<0.001$ & $<0.5$ & $<0.1$ \\
\hline Silo B & $3 / 30$ & 9:00 & & $<1$ & 3.6 & $<0.1$ & 0.32 & $<0.5$ & $<0.001$ & $<0.5$ & $<0.1$ \\
\hline
\end{tabular}

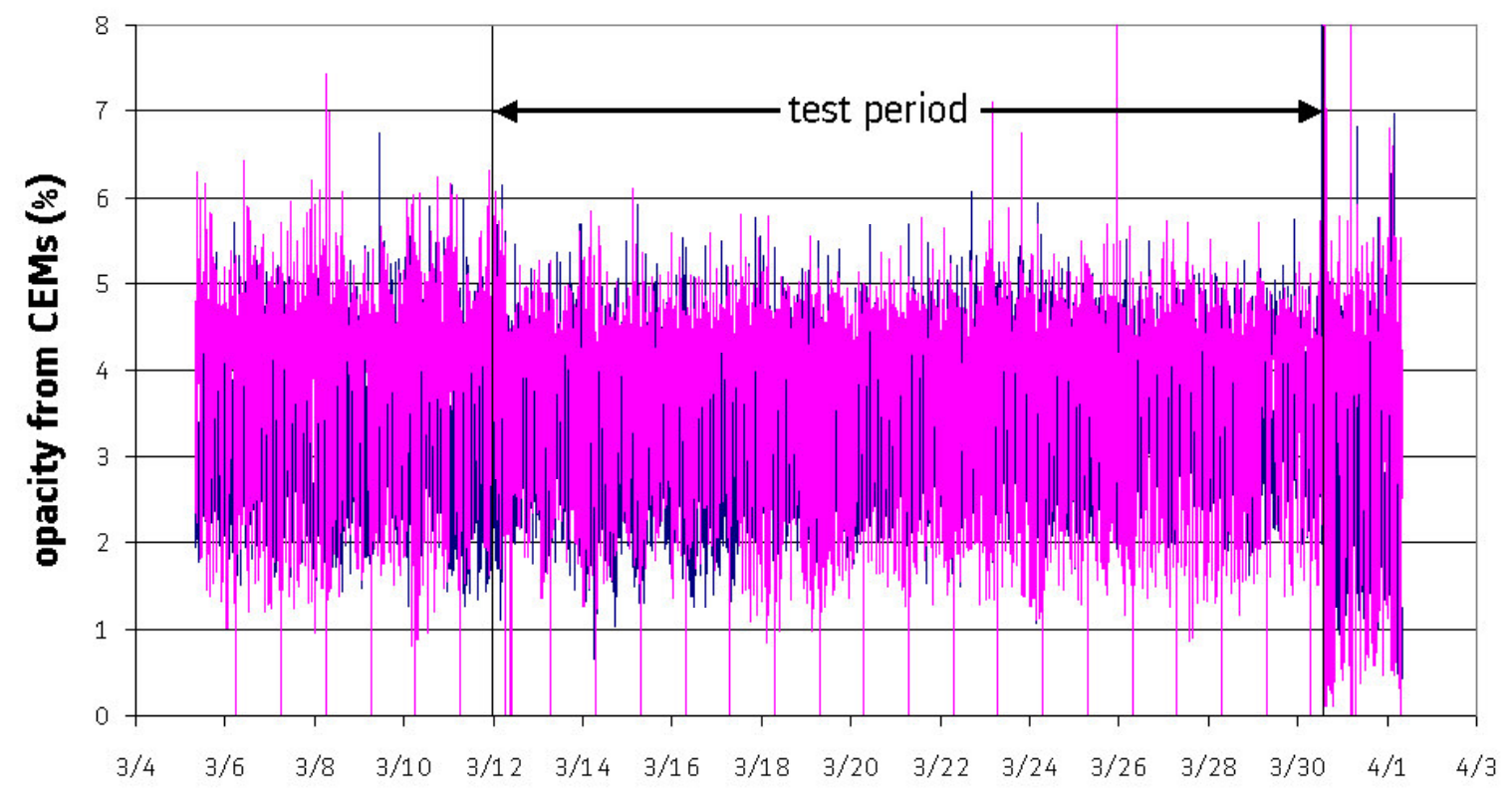

time

Figure 6.4-5 Measured Fayette Unit \#3 Opacity During Test Period 
Stack opacity was monitored during the entire test program. Plant opacity data obtained from the plant data historian are plotted in Figure 6.4-5. As shown, no change was observed for opacity during the test period. Observations throughout the Mercury Round 3 testing program suggest that injection of Mer-Clean ${ }^{\mathrm{TM}}$ sorbent did not increase the stack opacity during testing.

\subsection{Economics}

Capital and operating costs for the installation and operation of a Mer-Cure ${ }^{\mathrm{TM}}$ system for LCRA Fayette Unit \#3 are presented in Table 3, along with the assumptions included in the calculations. Capital costs include those for sorbent storage, sorbent processing and injection equipment, and were determined from vendor quotes. Equipment costs including all piping, materials and controls are estimated to be $\$ 1.32$ million. Installation, including site integration, is estimated around $\$ 518,000$. Adding in start-up support and a contingency of 10 percent of capital costs, the overall capital cost of the Mer-Cure ${ }^{\mathrm{TM}}$ system is estimated to be about $\$ 2.062$ million or about $\$ 4.30 / \mathrm{kW}_{\mathrm{e}}$.

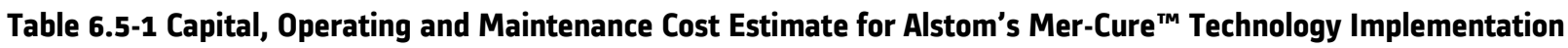
at Fayette Unit \#3 for 90 Percent Mercury Reduction

\begin{tabular}{|l|r|}
\hline \multicolumn{2}{|c|}{ Capital Costs Summary } \\
\hline Equipment & $\$ 1,320,000$ \\
\hline Installation including site integration (materials and labor) & $\$ 518,000$ \\
\hline Start-up support & $\$ 18,000$ \\
\hline Contingency & $\$ 206,000$ \\
\hline Total Capital Required & $\$ 2,062,000$ \\
\hline \$/kW (480 MW e gross) & 4.30 \\
\hline \multicolumn{2}{|c|}{ Operating and Maintenance Costs Summary } \\
\hline Sorbent (\$1.25/lb, 90\% reduction, 92 lb/h, 7,500 hrs) & $\$ 862,500$ \\
\hline Power, Labor and Maintenance & $\$ 115,000$ \\
\hline Loss of Ash Sale for Concrete (at \$20/ton ash) & $\$ 2,090,000$ \\
\hline Annual O\&M & $\$ 3,067,500$ \\
\hline Levelized - 20 year 0\&M Cost (\$/kW) & 8.41 \\
\hline \$MWh & 0.87 \\
\hline
\end{tabular}

Notes:
a) 90 percent mercury removal target
b) Unit is assumed to be base loaded
c) Ash is no longer utilized for concrete
d) Installation is with union labor
e) Contingency is calculated at $10 \%$ of capital cost
f) Levelized costs are calculated assuming 3\% increase per year
g) $480 \mathrm{MW}_{\mathrm{e}}$ gross capacity with 7500 hours operation per year 
Normally, the predominant component of the operating cost is the sorbent cost. Costs were estimated based on a long-term Mer-Clean ${ }^{T M} 8$ sorbent injection rate conservatively assumed to be $0.84 \mathrm{lb} /$ MMacf or $92 \mathrm{lb} / \mathrm{hr}$. Unit operation is assumed at 85 percent capacity factor. With these assumptions, the annual sorbent costs are $\$ 862,500$, assuming a delivered sorbent cost of $\$ 1.25 / \mathrm{lb}$. There is a significant uncertainty in the cost for the sorbent because of anti-dumping tariffs being imposed on imported activated carbon and because of anticipated increased demand for activated carbon. The tariff amounts are expected to be around $\$ 0.25$ to $\$ 0.30 / \mathrm{lb}$. This almost doubles the cost of imported activated carbon which is currently around $\$ 0.30-0.40 / \mathrm{lb}$. The tariffs and increased demand for active carbon may both lead to an increase in the custom-enhanced sorbent costs, even for carbon produced domestically.

At $90 \%$ mercury reduction, the demonstration program results show that Fayette Unit \#3 would no longer be able to sell their fly ash for concrete applications. In this case, the lost revenue from the ash sale becomes the predominant component of operation cost. With the assumptions shown in Table 6.5-1 and the average coal quality from Table 6.1-1, the annual ash generated is 1.045 million tons. At $\$ 20 /$ ton, the operating cost associated with the lost ash sale is $\$ 2.09$ million.

The other component of the operating cost is parasitic power, labor and maintenance and this is estimated to be $\$ 115,000$ annually. The overall operating cost for Fayette Unit \#3 for 90 percent mercury control is $\$ 3,067,500$ or $\$ 0.87 / \mathrm{MWH}$.

Table 6.5-2 can be used to calculate the operating cost if lower levels of mercury removal are required. For example, if 70 percent reduction is required the sorbent injection rate is 0.33 $\mathrm{lbs} / \mathrm{MMacf}$ (36 lb/hr). If 80 percent reduction is required, the sorbent injection rate is 0.50 lbs/MMacf (55 lb/hr).

Table 6.5-2 Sorbent Consumption Rates as a Function of Mercury Removal Level for Mer-Cure ${ }^{\mathrm{TM}}$ Technology Implementation at Fayette Unit \#3

\begin{tabular}{|c|c|c|}
\hline $\begin{array}{c}\text { \% Mercury } \\
\text { Removal }\end{array}$ & $\begin{array}{c}\text { Sorbent } \\
\text { (lb/MMacf) }\end{array}$ & $\begin{array}{c}\text { Sorbent } \\
\text { (lb/hr) }\end{array}$ \\
\hline 60 & 0.22 & 25 \\
\hline 70 & 0.33 & 36 \\
\hline 75 & 0.40 & 44 \\
\hline 80 & 0.50 & 55 \\
\hline 90 & 0.84 & 92 \\
\hline 95 & 1.17 & 129 \\
\hline
\end{tabular}

Sensitivity analysis for Fayette Unit \#3 with respect to the mercury removal level required and unit sorbent costs are shown in Figure 6.5-1. The line on this figure labeled "Sorbent price $=\$ 1.25$ " shows the big impact that ash sales have on the overall economics of mercury reduction. At $75 \%$ reduction and below, the ash sale is maintained and the mercury removal costs are $\$ 0.16 / \mathrm{MWH}$ or less at a sorbent cost of $\$ 1.25 / \mathrm{lb}$. (All assumptions are the same as those listed in Table 6.5-1). 
Once sufficient sorbent is injected to achieve above $75 \%$ mercury reduction, sale of the ash for concrete is not longer possible and operating costs rise significantly, to $\$ 0.57 / \mathrm{MWH}$ at $80 \%$ reduction and increasing from there.

The lines labeled "Injection for 75\% removal" and "Injection for 90\% removal" also show the dramatic effect of ash sale economics on operating costs. These calculations indicate that at $75 \%$ mercury control, the operating cost ranges from $\$ 0.10 / \mathrm{MWH}$ to $\$ 0.26 / \mathrm{MWH}$. However, at $90 \%$ mercury control, the operating cost increases to a range of $\$ 0.76 / \mathrm{MWH}$ to $\$ 1.05 / \mathrm{MWH}$.

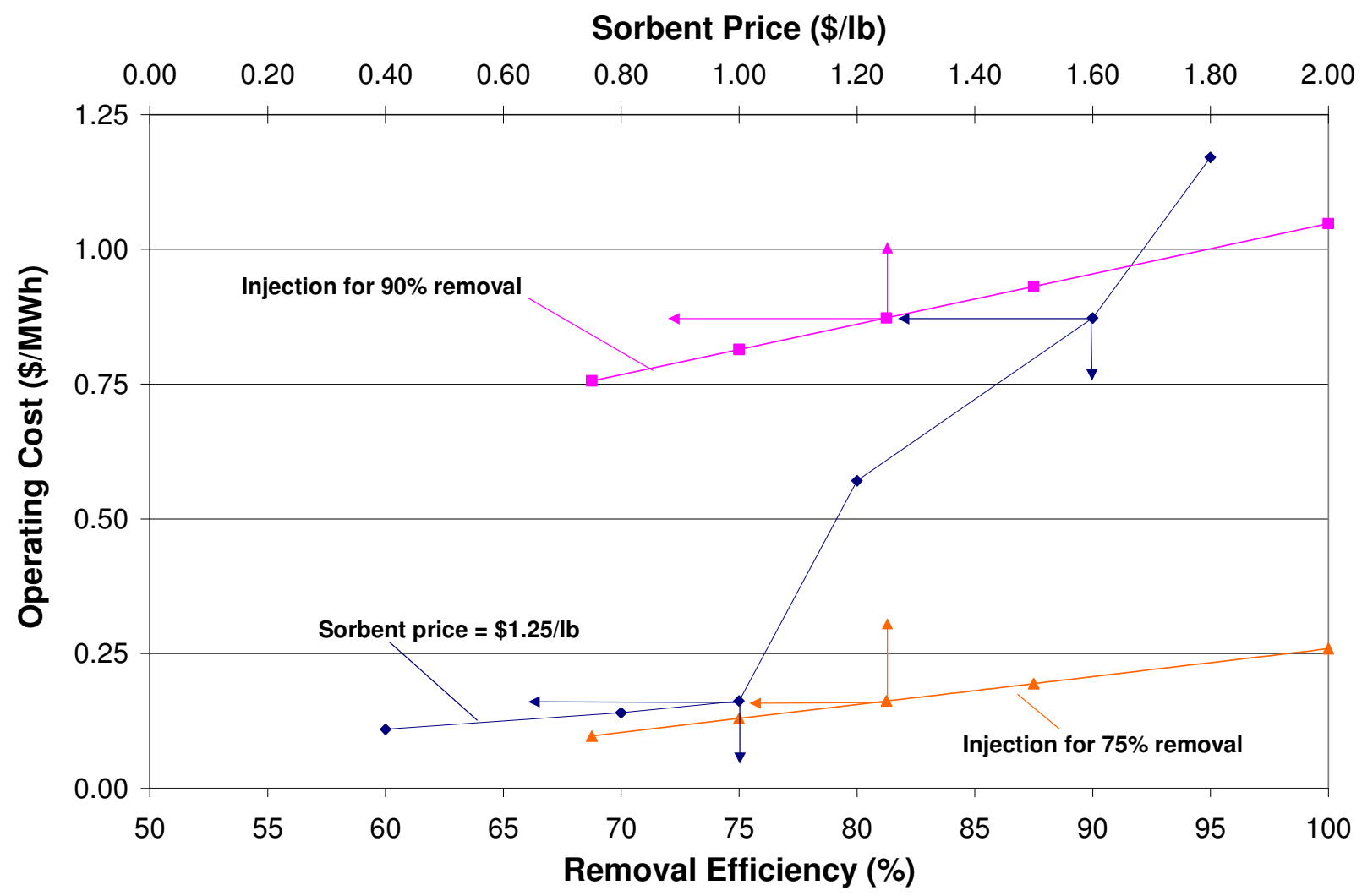

Figure 6.5-1 Sensitivity analysis: Effect of Sorbent Unit Cost and Mercury Removal Required on Operating Cost for

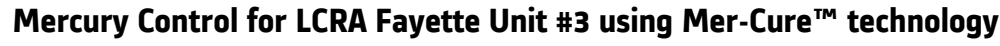

\subsection{Conclusions}

Field demonstration of the Mer-Cure ${ }^{T M}$ system has been completed at Fayette Unit \#3. The goals of the program, as originally defined by DOE/NETL in the solicitation, are to demonstrate that MerCure $^{\mathrm{TM}}$ technology can achieve:

- Greater than $90 \%$ reduction of gaseous mercury in the flue gas;

- At a mercury control cost significantly lower than $50 \%$ of $\$ 60,000 /$ lb mercury removed.

Alstom-PPL also collected performance data to evaluate the long-term impact of mercury control on the operation of power plants and overall plant economics. LCRA was also interested in determining 
the maximum mercury reduction possible while maintaining the capability to sell their fly ash for concrete applications.

The first performance goal was achieving 90\% mercury reductions. Two of the four sorbents tested achieved $90 \%$ mercury reductions, and the other two sorbents were not tested at injection rates above $0.5 \mathrm{lb} / \mathrm{MMacf}$ because of time constraints. In the ash evaluation tests, foam index test measurements indicated that the ash generated with sorbent injection to achieve $90 \%$ mercury reductions would likely be unsuitable for concrete applications. Figure 6.6-1 summarizes the parametric test mercury reduction results and the maximum mercury reduction possible while maintaining ash quality for sale.

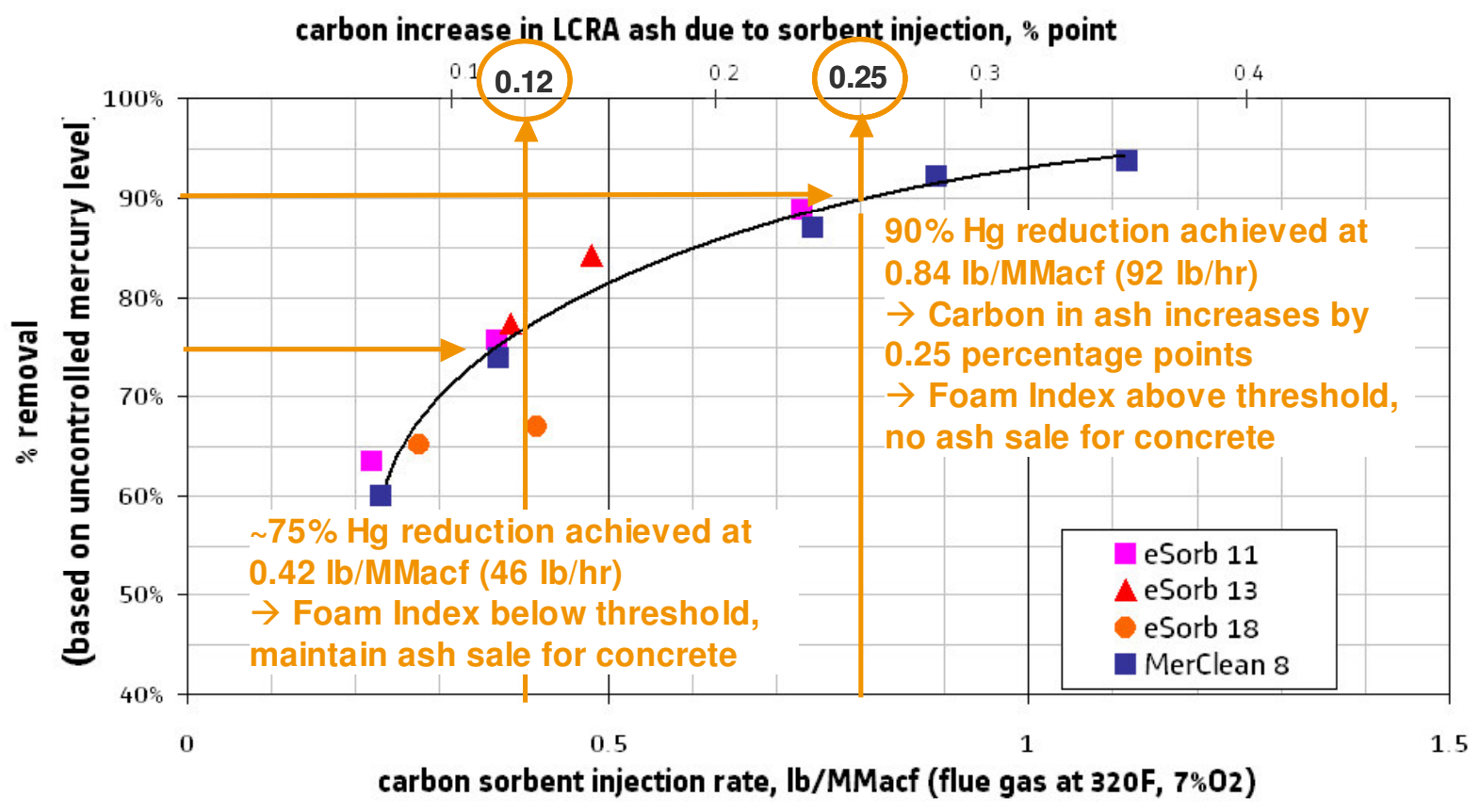

Figure 6.6-1 Mercury Reduction Performance Summary for Fayette Unit \#3

Figure 6.6-1 shows that the performance goal of $90 \%$ mercury reduction could be achieved if sale of the fly ash were sacrificed. A 75\% mercury reduction could be achieved while maintaining sale of the fly ash for concrete applications.

The second performance goal was achieving $90 \%$ mercury reduction at a mercury removal cost significantly lower that $50 \%$ of the assumed baseline cost of $\$ 60,000 / \mathrm{lb}$ mercury removed. For the purposes of this discussion, "significantly lower than $50 \%$ " is defined as at least $60-70 \%$ below the assumed baseline cost of $\$ 60,000 /$ lb mercury removed.

Figure 6.6-2 shows mercury removal costs (in $\$ / \mathrm{lb} \mathrm{Hg}$ removed) at sorbent injection rates to achieve both $75 \%$ and $90 \%$ mercury reduction. The figure shows very low removal costs for $75 \%$ reduction ( $\$ 2100-5700 / \mathrm{lb} \mathrm{Hg}$ removed at $\$ 0.75-2.00 / \mathrm{lb}$ sorbent) because only $46 \mathrm{lb} / \mathrm{hr}$ sorbent is required to achieve $75 \%$ reduction, and testing indicated that the fly ash sale for concrete could be maintained. The removal costs at $90 \%$ reduction levels are significantly higher $(\$ 13,400-18,700 / \mathrm{lb} \mathrm{Hg}$ removed 
at $\$ 0.75-2.00 / \mathrm{lb}$ sorbent). Sorbent costs are doubled, because $92 \mathrm{lb} / \mathrm{hr}$ sorbent flow is required to achieve $90 \%$ reduction, but the inability to sell ash for concrete accounts for the majority of the cost increase. Even with the ash effects, the removal costs at $90 \%$ reduction are over $70 \%$ below the baseline cost of $\$ 60,000 / \mathrm{lb} \mathrm{Hg}$ removed at sorbent costs below $\$ 2.00 / \mathrm{lb}$. Even at $\$ 2.00 / \mathrm{lb}$ sorbent, the removal cost is $\$ 18,700 / \mathrm{lb}$ or $68.8 \%$ below $\$ 60,000 / \mathrm{lb} \mathrm{Hg}$ removed.

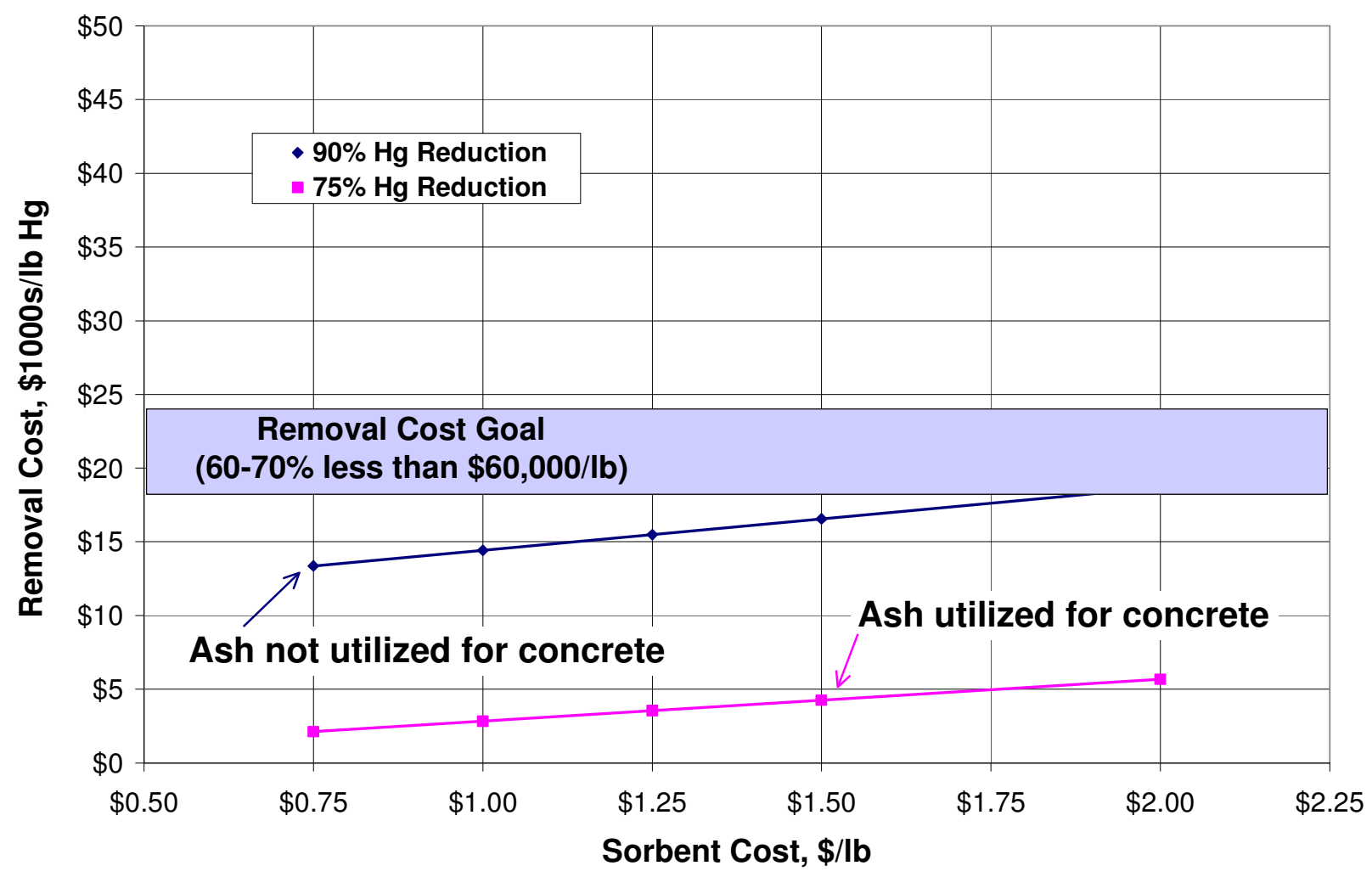

Figure 6.6-2 Mercury Removal Costs for LCRA Fayette Unit \#3 


\section{Commercialization of Mer-Cure ${ }^{T M}$ Process}

The timing of commercialization for mercury capture technology is driven largely by mercury reduction regulations. Regulations have consisted of proposed federal regulations plus a variety of proposed and enacted state regulations. On February 8, 2008, the DC Circuit Court of Appeals struck down EPA rules known as the Clean Air Mercury Rule or CAMR, in response to an appeal by 18 states and several environmental groups. ${ }^{12}$ The petitioners questioned EPA's decision to delist coal and oil-fired power plants from the list of sources that produce hazardous air pollutants (including mercury). The court agreed, finding that EPA did not go through the proper process before delisting. As a result, mercury emissions trading is illegal; instead mercury will be subject to yet-to-bespecified command-and-control regulations.

On July 11, 2008, the DC Circuit Court of Appeals also struck down the Clean Air Interstate Rule (CAIR), saying it contains "several fatal flaws." ${ }^{13}$ That regulation was aimed at reducing emissions of sulfur dioxide and nitrogen oxides from power plants in 28 eastern states and the District of Columbia, and would have required most large utility boilers to install scrubbers for $\mathrm{SO}_{2}$ control and selective catalytic reduction ( $\mathrm{SCR}$ ) systems for $\mathrm{NO}_{\mathrm{x}}$ control. When the two pollution control devices are combined, the SCR often oxidizes the elemental mercury in the gas phase and the wet scrubber often collects a significant portion of the water-soluble oxidized mercury. The CAIR requirements were expected to result in a co-benefit of significant mercury capture because of this characteristic.

The effective result is that state regulations are now driving the near-term commercialization of mercury capture technology. For utilities with units currently under state regulation, there is an understanding that new federal regulations are forthcoming, but they are required to implement solutions to meet the current state regulations.

\subsection{Commercial Mer-Cure ${ }^{\mathrm{TM}}$ System Design}

Alstom's Mer-Cure ${ }^{\mathrm{TM}}$ technology employs a sorbent preparation and injection system consisting of four (4) major subsystems as follows:

- Bulk Storage and Feed

- Transport

- Processing

- Distribution and Injection

The bulk storage and feed system receives PAC sorbent delivered by tank trucks. Sorbent is conveyed pneumatically from the truck into a fabricated storage silo. The sorbent is fed into a hopper where it is temporarily stored until fed into the drop tube by the variable speed screw feeder and into an eductor inlet.

Motive air, supplied from air compressors, passes through the eductor nozzle and creates a vacuum in the eductor inlet, resulting in the sorbent being drawn into the mixing zone and exiting the transport system. Sorbent is conveyed via conventional piping to the sorbent processor where highpressure air from the compressors is used to process the sorbent before it enters the distributors and the injection lances. 
Additional motive air from the compressors is added downstream of the sorbent processor in order to ensure that the processed sorbent continues to be entrained and enters the distribution at the correct velocity. Distribution is achieved via splitters that divide the sorbent flow between the flue gas ducts (typically, two) and additional splitters that direct the sorbent flow to the different injection lances.

Overall system operation is controlled via programmable logic controllers for the silo and feed system, and Alstom-supplied control logic for the overall control system, which can be programmed into the plant's existing Distributed Control System (DCS).

All components integrated into an assembled Mer-Cure ${ }^{T M}$ system are commercially available for systems of various sizes and capacities, with one exception. The injection lances and nozzles are designed and fabricated specifically for each site.

\subsection{Status of Mer-Cure ${ }^{T M}$ Commercialization Efforts}

Since completion of the field testing for this DOE project, Alstom has conducted multiple commercial demonstrations at electric utility boilers for several generating companies. One of the demonstrations has resulted in the first large commercial installation contract for Mer-Cure ${ }^{\mathrm{TM}}$ technology. At least one other multiple unit installation of Mer-Cure ${ }^{\mathrm{TM}}$ technology is under consideration by a second utility.

Alstom and Reliant Energy, Inc., one of the largest independent power producers in the United States, have announced the contract signing for the purchase of Alstom's advanced mercury removal system, Mer-Cure ${ }^{\mathrm{TM}}$. $^{14}$ The deal follows the successful launch of Alstom's Mer-Cure ${ }^{\mathrm{TM}}$ product line in 2007, marking Alstom's entry into this new market. The Mer-Cure ${ }^{\mathrm{TM}}$ system delivers reductions in flue gas mercury emissions of up to $90 \%$ and more, at low sorbent consumption rates, thus trimming operation and maintenance costs.

The system will be installed at Reliant's Shawville, Conemaugh, Titus, Portland and New Castle power stations in Pennsylvania. Delivery is scheduled for early 2009. This is in response to Pennsylvania's mercury capture regulations, Phase I of which take effect on January 1, 2010. 


\section{Summary of Demonstration Program Results}

Following is the summary of the Fayette Unit \#3 test campaign results discussed in this final report.

Baseline

- Baseline measurements showed that the native capture of mercury at Fayette Unit \#3 is approximately $50 \%$. About $27 \%$ capture was observed across air heaters and ESP's and $23 \%$ across wet scrubbers.

- During the baseline measurement period, only $36 \%$ of the oxidized mercury was captured by wet scrubbers. A significant amount of oxidized mercury was reduced to elemental mercury in the wet scrubber modules.

- At the ESP outlet, gaseous mercury was $20 \%$ elemental / $80 \%$ oxidized. At the wet scrubber outlet, gaseous mercury was $72 \%$ elemental / $28 \%$ oxidized. Absolute levels of elemental mercury increased from 1.7 to $4.2 \mu \mathrm{g} / \mathrm{m}^{3}$, indicating reemission of elemental mercury by the scrubber.

Mercury Capture Performance

- $\quad$ Mer-Cure ${ }^{T M}$ performance was determined for four sorbents: Mer-Clean ${ }^{T M}$ 8, eSorb ${ }^{T M} 11$, eSorb $^{T M} 13$, and eSorb ${ }^{T M}$ 18. eSorb ${ }^{T M} 11$ performed better than Mer-Clean ${ }^{T M} 8$ or eSorb $^{T M} 13$. eSorb $^{\text {TM }} 18$ performed the worst.

- Mercury capture performance at Fayette Unit \#3 showed that at an injection rate of 0.84 $\mathrm{lb} / \mathrm{MMacf}$, the mercury removal rate was greater than $90 \%$ based on the uncontrolled mercury level at the stack. About $0.5 \mathrm{lb} /$ MMacf was needed to achieve $90 \%$ reduction based on the input mercury.

- At an injection rate of $0.42 \mathrm{lb} / \mathrm{MMacf}$, the mercury removal rate was greater than $75 \%$ based on the uncontrolled mercury level at the stack and greater than $88 \%$ based on the input mercury.

Ash Evaluation

- Foam index tests were conducted by MRT with simulated ash-sorbent mixtures. ESorb ${ }^{\mathrm{TM}} 18$ performed the best followed by eSorb ${ }^{T M} 13$ eSorb $^{T M} 11$, and Mer-Clean ${ }^{T M} 8$.

- Continuous injection testing was conducted with two sorbents for ash evaluation: MerClean $^{\mathrm{TM}} 8$ and eSorb ${ }^{\mathrm{TM}} 11$. Ninety percent capture of baseline mercury was achieved for both sorbents during week long continuous injection testing.

- The silo ash collected during continuous injection and characterized for foaming tendency verified the results from the simulated ash-sorbent testing.

- Analysis indicates that for Mer-Clean ${ }^{\mathrm{TM}} 8$ sorbent, a reduction of $75 \%$ of baseline mercury or $88 \%$ of input mercury can be achieved while still allowing continued ash sales.

- Analysis indicates that for eSorb ${ }^{\mathrm{TM}} 13$ sorbent, a reduction of $85 \%$ of baseline mercury or $92 \%$ of input mercury can be achieved while still allowing continued ash sales. 


\section{Economics}

- Overall capital cost of the Mer-Cure ${ }^{\mathrm{TM}}$ system is estimated to be about $\$ 2.06$ million or $\$ 4.30 / \mathrm{kWe}$.

- The overall operating cost for 75 percent mercury removal is $\$ 546,250$ or $\$ 0.16 / \mathrm{MWh}$, assuming a delivered sorbent price of $\$ 1.25 / \mathrm{lb}$.

- The overall operating cost for 75 percent mercury removal is $\$ 3,067,500$ or $\$ 0.87 / \mathrm{MWh}$, assuming a delivered sorbent price of $\$ 1.25 / \mathrm{lb}$ and ash valued at $\$ 20 /$ ton.

- If sorbent price increases to $\$ 2.00 / \mathrm{lb}$, the Mer-Cure ${ }^{\mathrm{TM}}$ operating cost increases to $\$ 0.26 / \mathrm{MWh}$ and $\$ 1.05 / \mathrm{MWh}$ for 75 and 90 percent mercury removal, respectively.

Balance of Plant Impacts:

- Observations throughout the long-term testing suggest that injection of Mer-Clean ${ }^{\mathrm{TM}}$ sorbent did not increase the stack opacity during long-term testing.

- Ash leaching test results indicate that no detectable mercury leached out. 


\section{References}

1. Feeley, T., Brickett, L.A., O’Palko, B.A., and Murphy, J.T., DOE/NETL Mercury R\&D Program Review, May 2005; http://www.netl.doe.gov/technologies/coalpower/ewr/pubs/mercuryR\%26D-v4-0505.pdf

2. Feeley, T., Overview of DOE/NETL's Mercury R\&D Program, July 2005 http://www.netl.doe.gov/publications/proceedings/05/Mercury/pdf/Feeley-071205-am.pdf

3. Dombrowski, K.; 2006 Mercury Control Technology Conference, Pittsburgh, PA, 2006.

4. Dunham, G.; Hill-Brandt, K.; Olson, E.; Pavlish, J.; The Proceedings of the 31st International Technical Conference on Coal Utilization and Fuel Systems, Clearwater, FL, 2006.

5. Sjostrom, S.; 2006 Mercury Control Technology Conference, Pittsburgh, PA, 2006.

6. http://www.power.alstom.com/ looks/alstomV2/frontofficeScripts/index.php?languageld= EN\&docld=36673\&dir=/home/equipment___systems/ecs/power/mercury_control/pilot_pl ant/knx/ (accessed July 2008)

7. Gebler, S. H.; Klieger, P. Publication No. RD085.01T, Portland Cement Association (1983).

8. Gao, Y.-M.; Shim, H.-S.; Hurt, R. H.; Suuberg, E. M. Energy Fuels 1997, 11, 457-462.

9. Freeman, E.; Gao, Y.-M.; Hurt, R.; Suuberg, E. Fuel 1997, 76, 761-765.

10. Senior, C., Baldrey, K., Starns, T., Durham, M., Paper \# 87, Mega Symposium 2003

11. Pavlish, J., Sondreal, E.A., Mann, M.D., Olson, E.S., Galbreath, K.C., Laudal, D.L. and Benson, S.A., Fuel Processing Technology, 82 (2003) pp. 89-165

12. Chemical and Engineering News, February 18, 2008 p.6

13. Chemical and Engineering News, July 21, 2008 p.12

14. Projects and Contracts, Power Engineering, July 2008 p. 34 


\section{Appendices}

Appendix A Ontario Hydro Test Results

Appendix B CMM Screens

Appendix C Coal and Ash Analyses 


\section{Appendix A Ontario Hydro and Sorbent Trap Test Results}

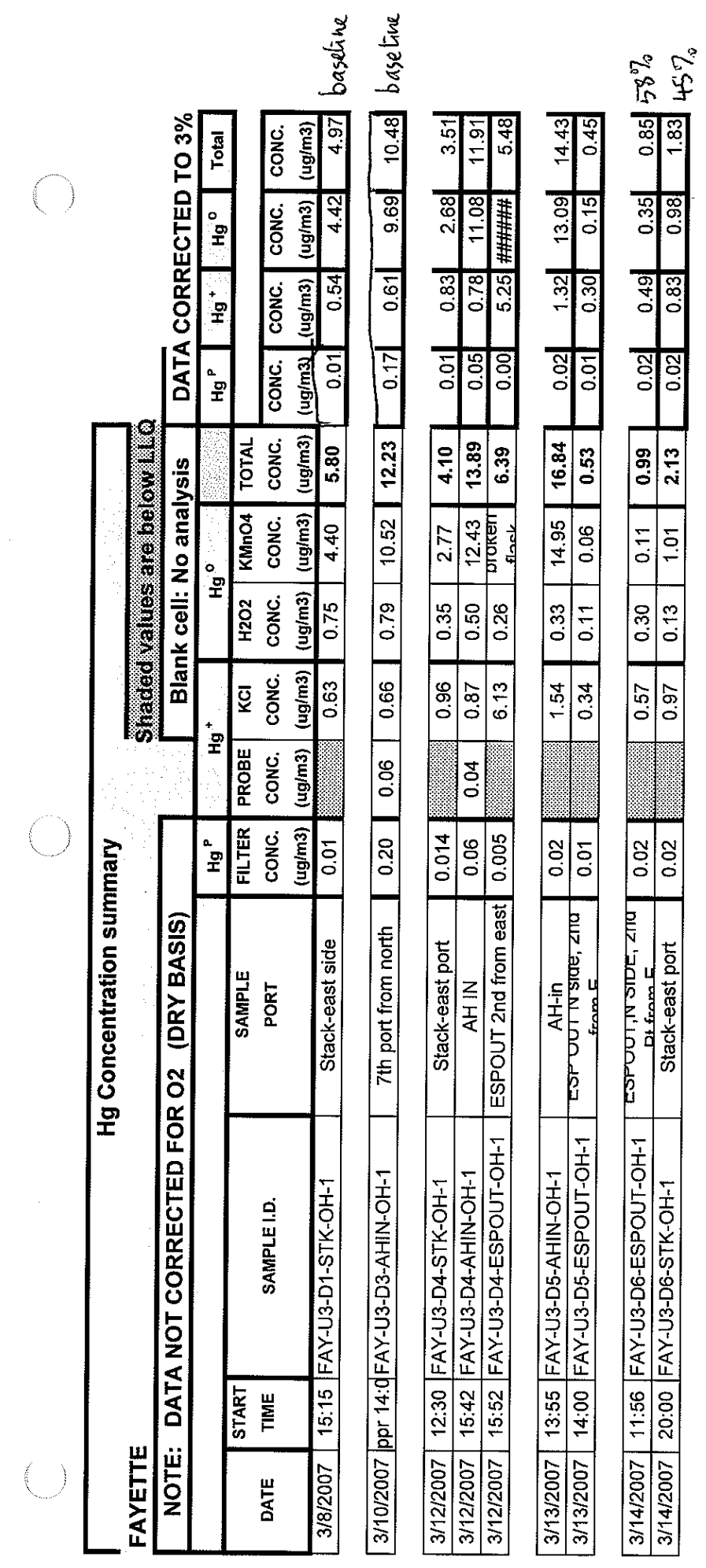




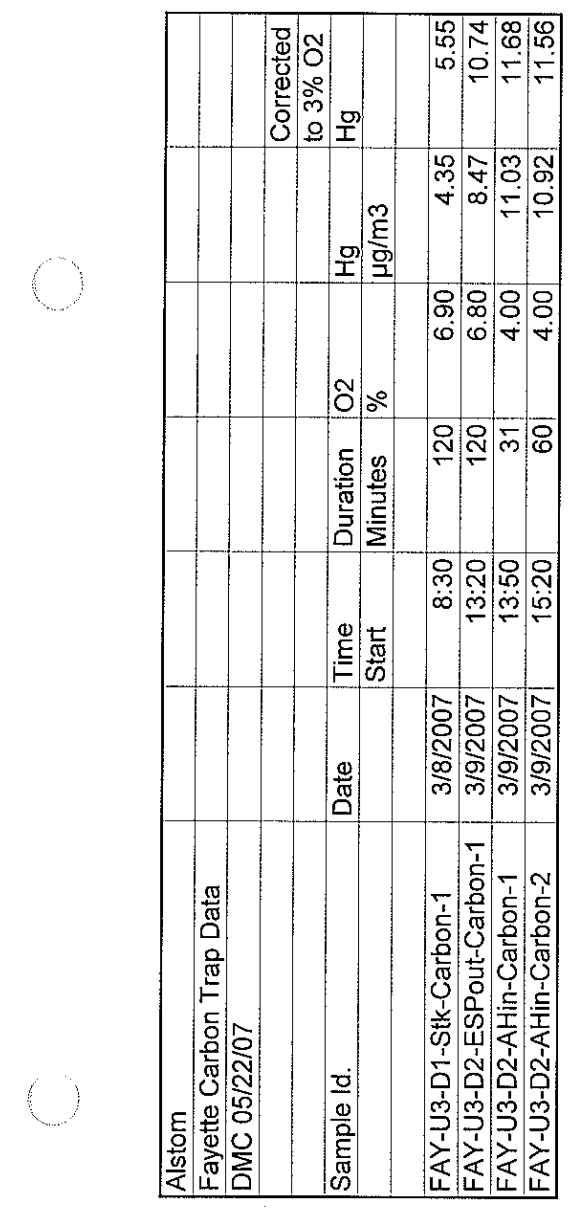

Alstom Power Inc. 


\section{Appendix B CMM Screens}

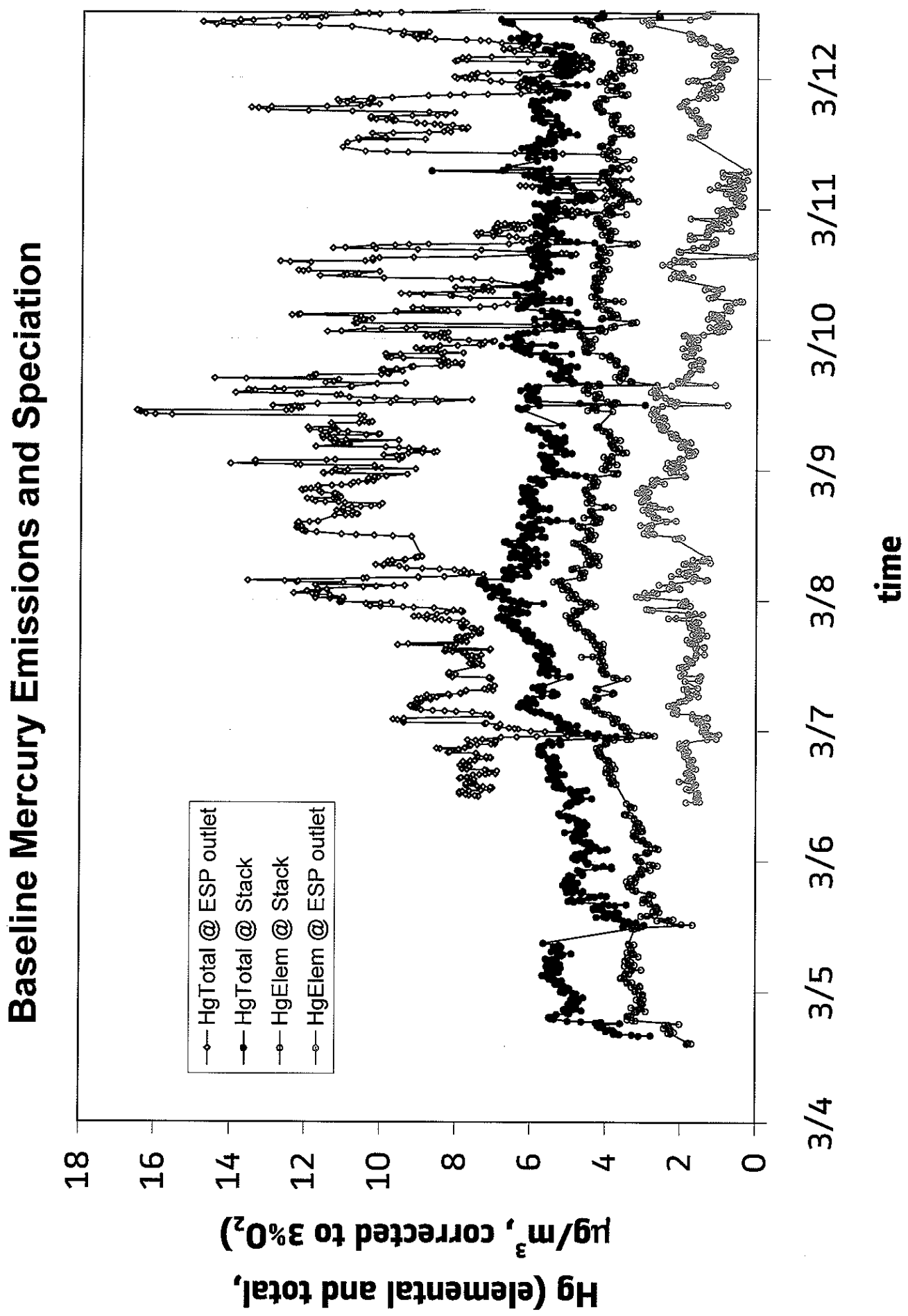

Alstom Power Inc. 


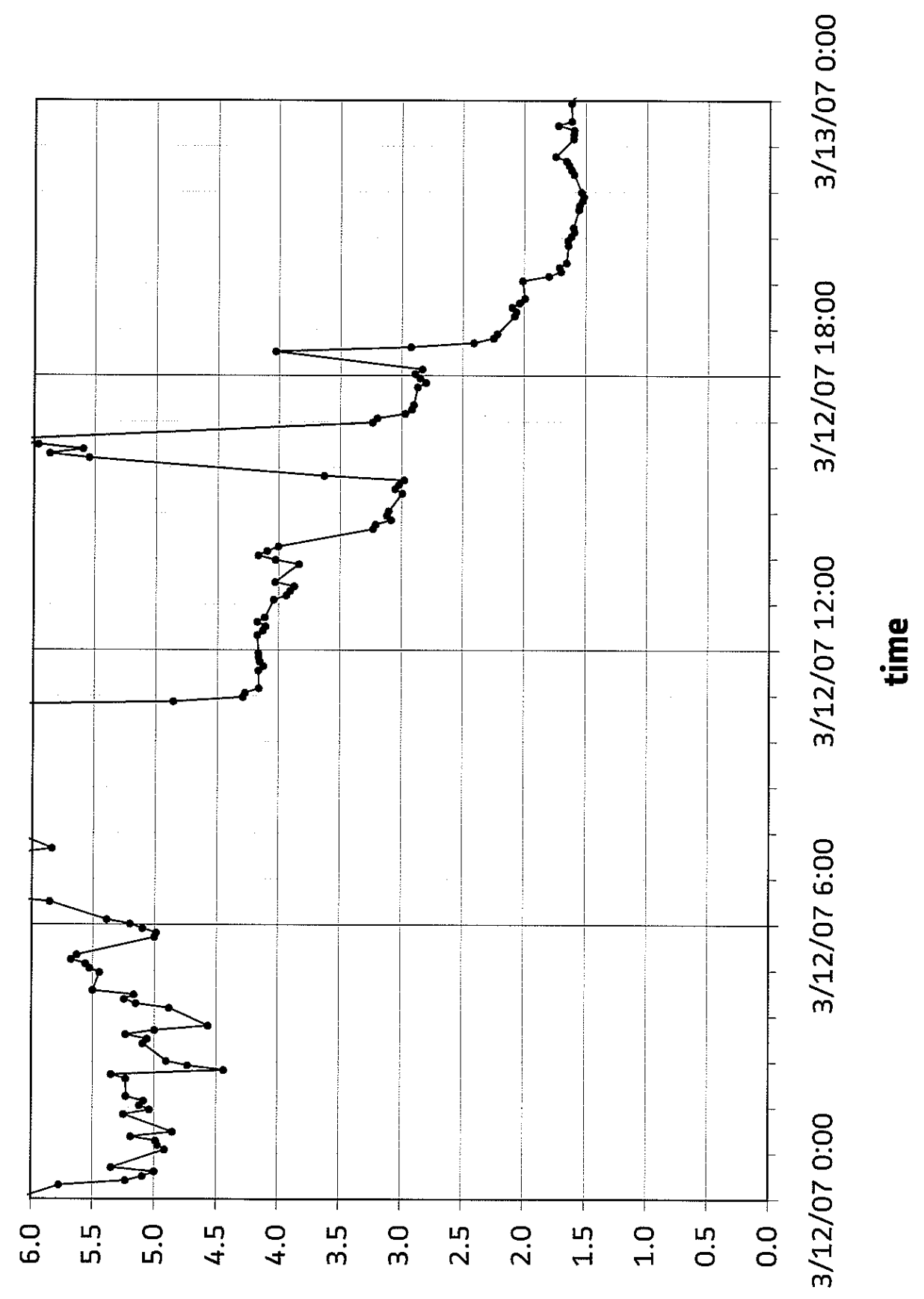

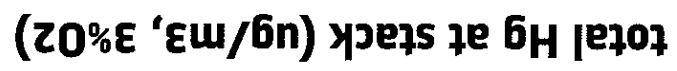




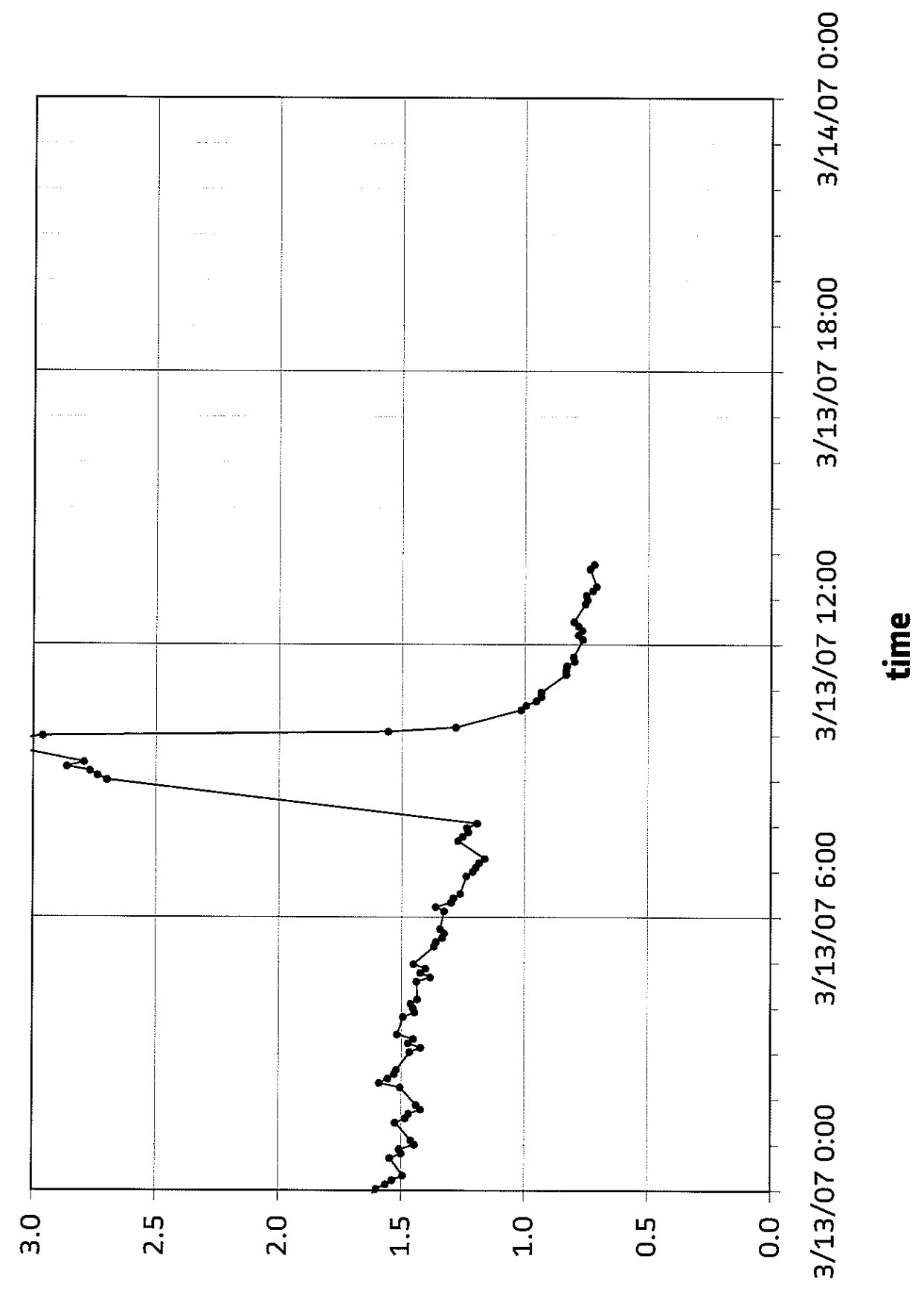

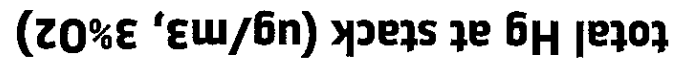




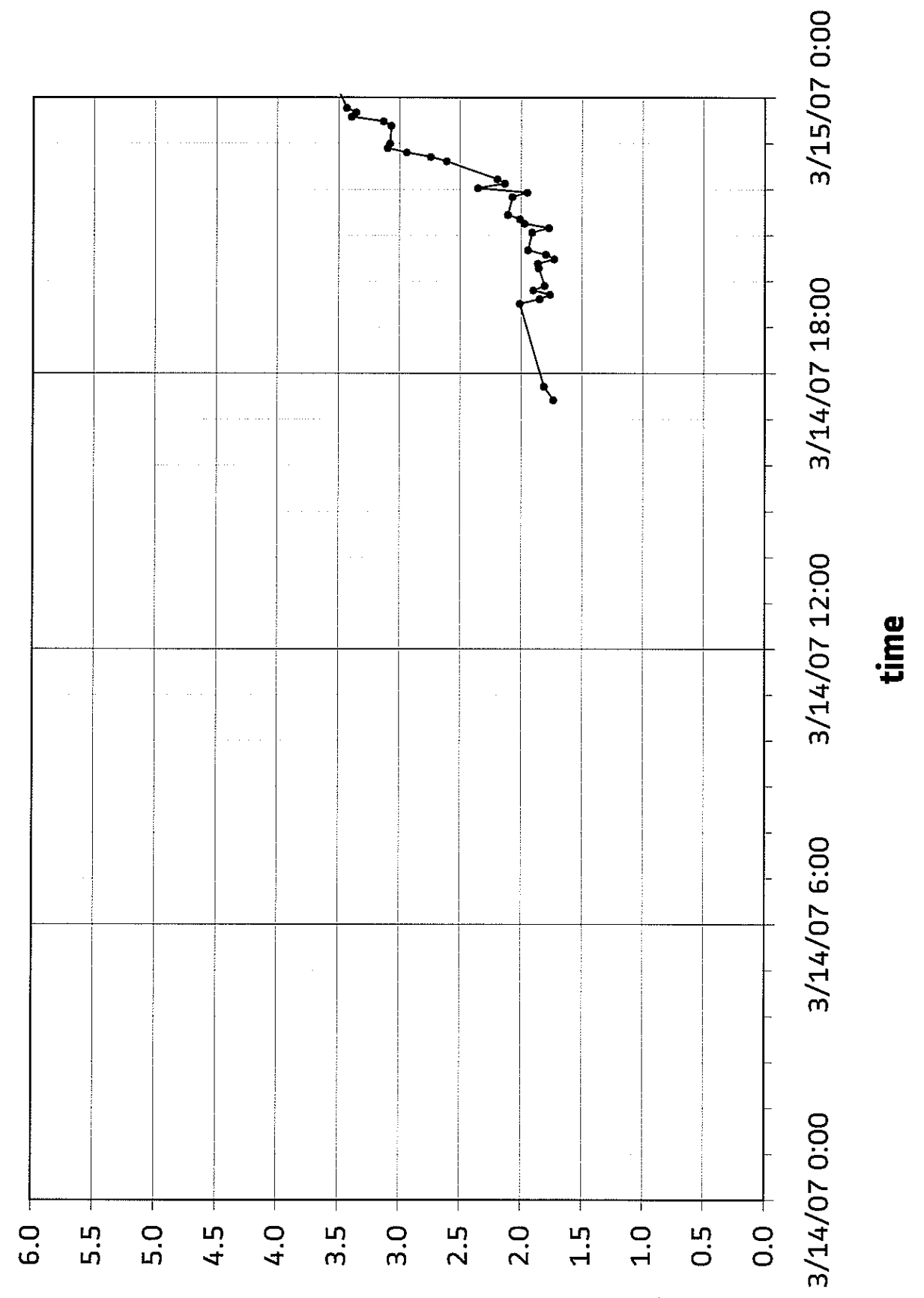

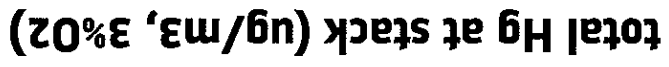




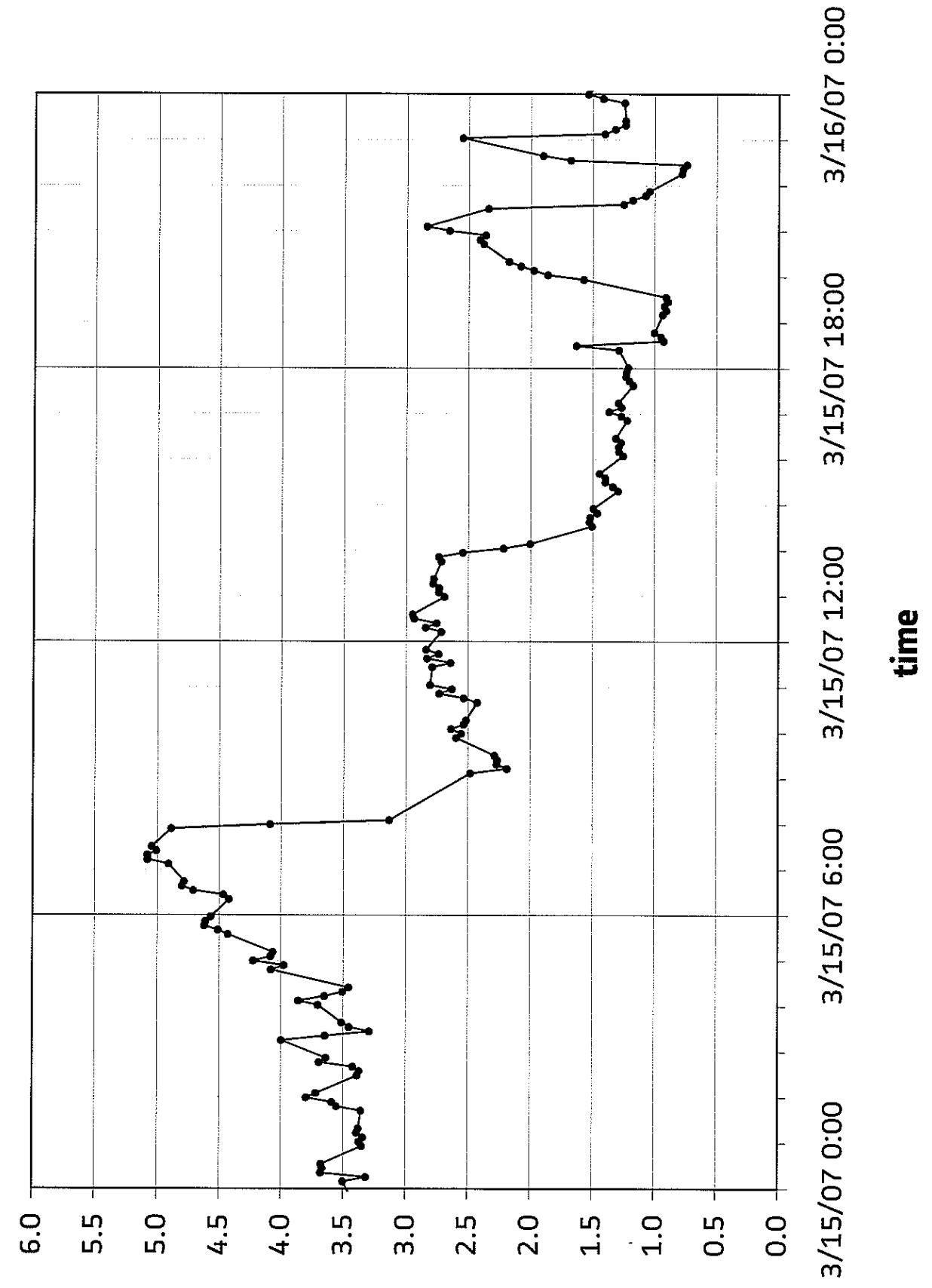

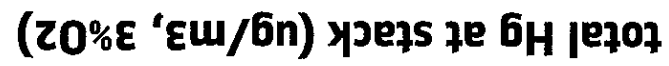




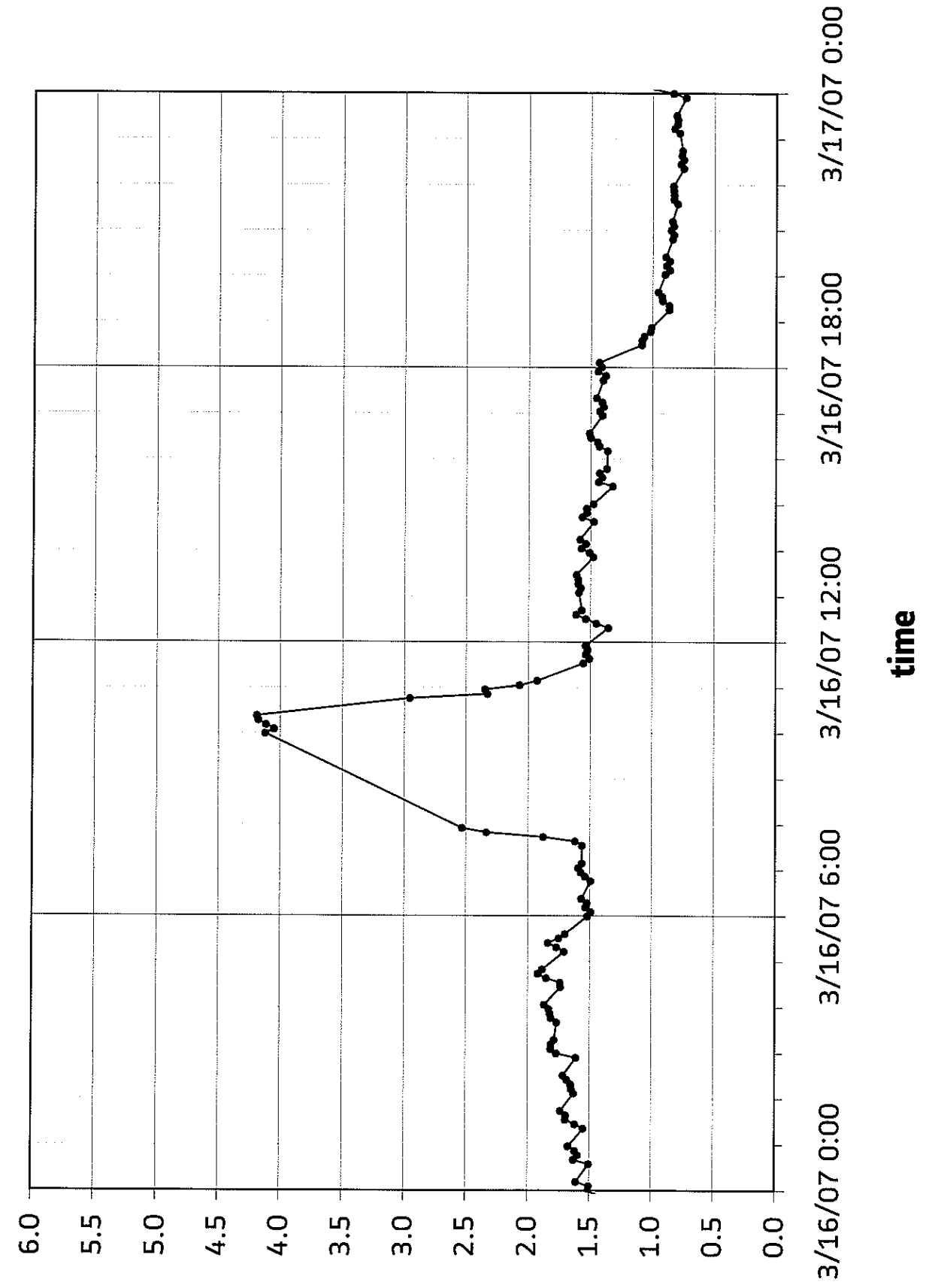

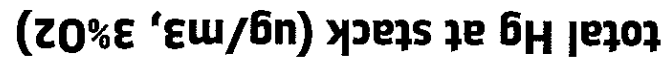




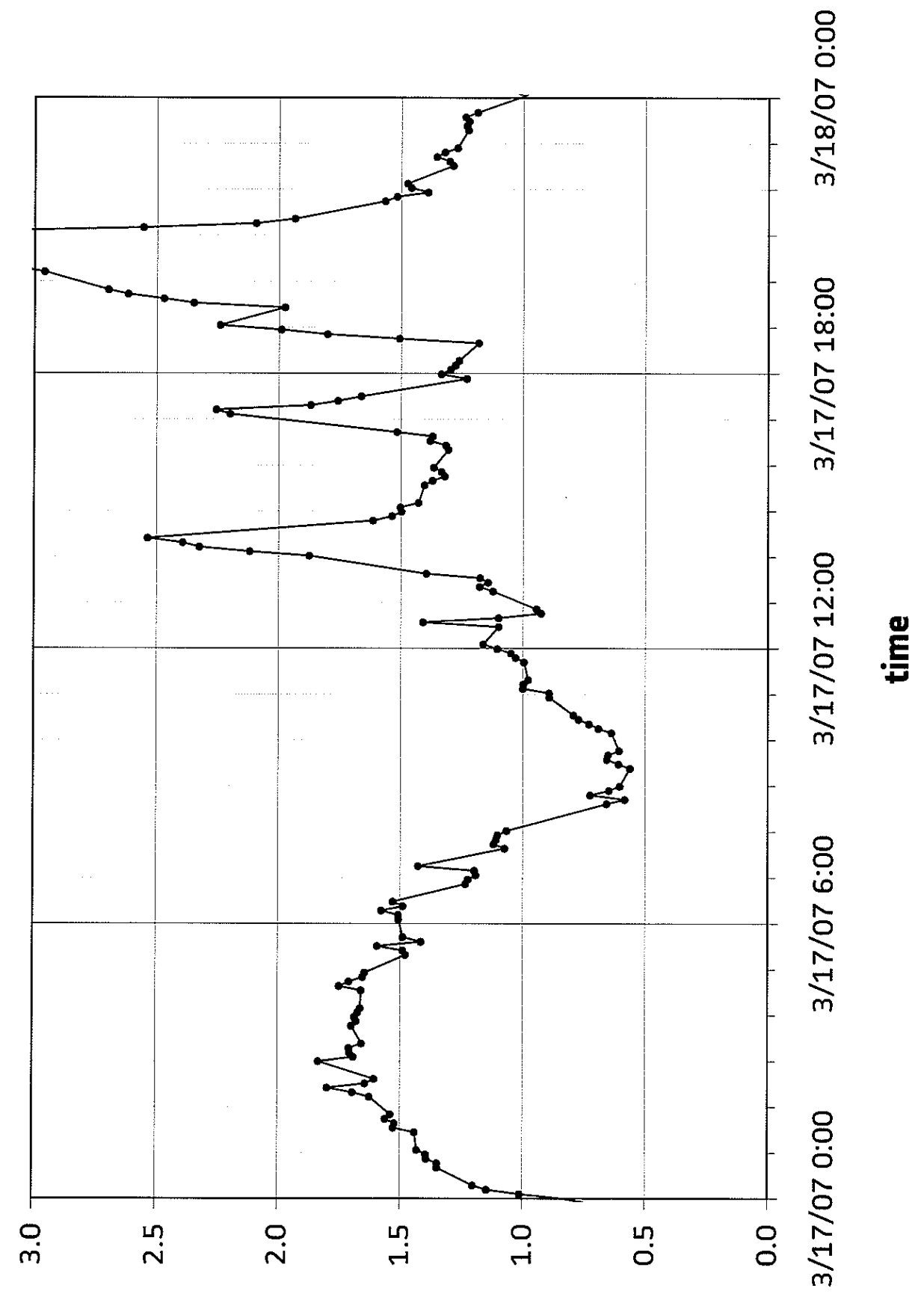

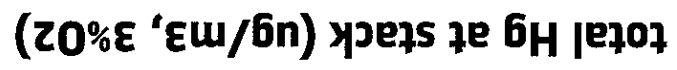




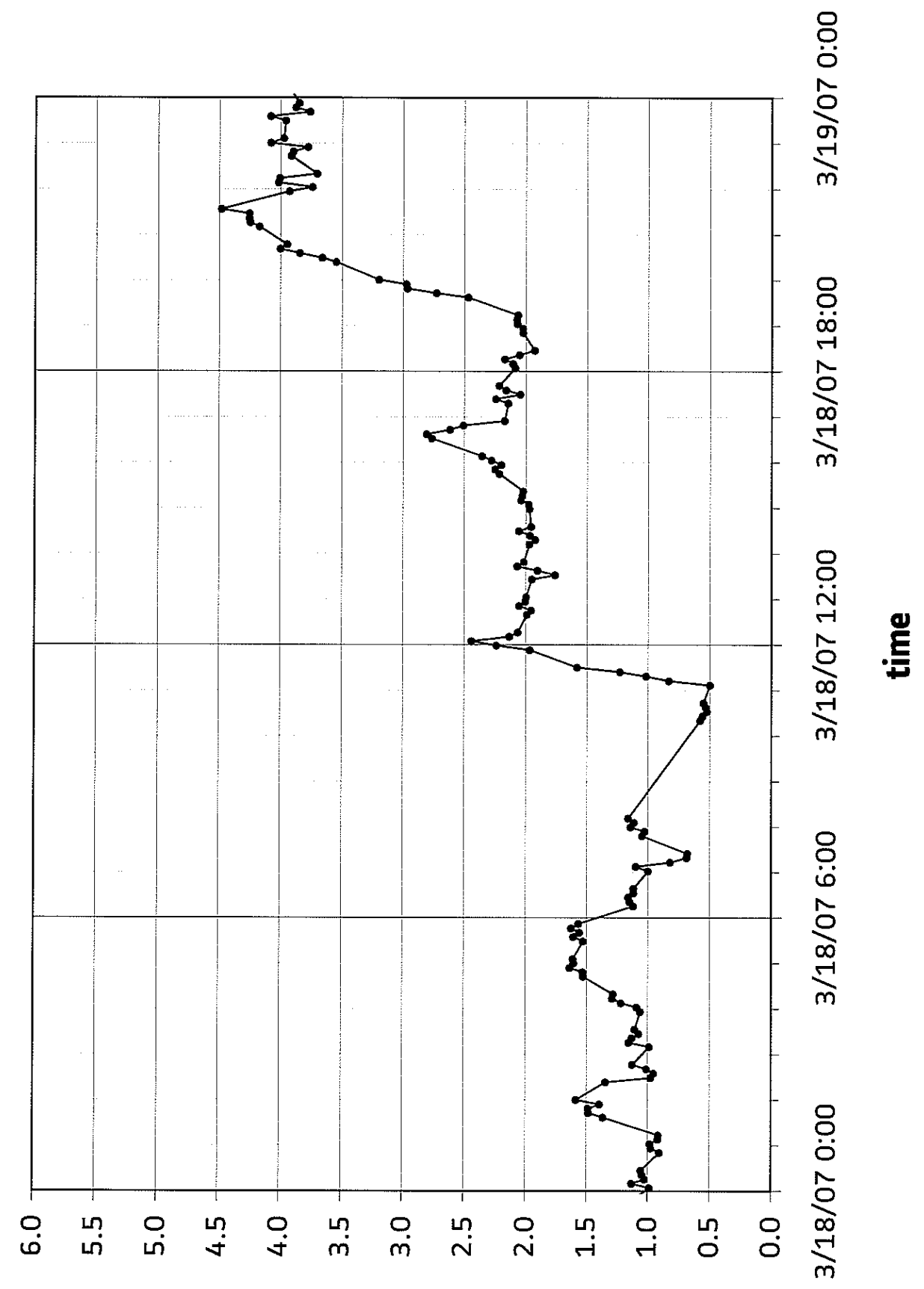

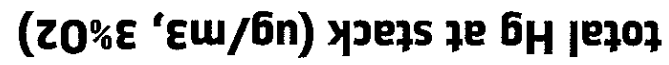




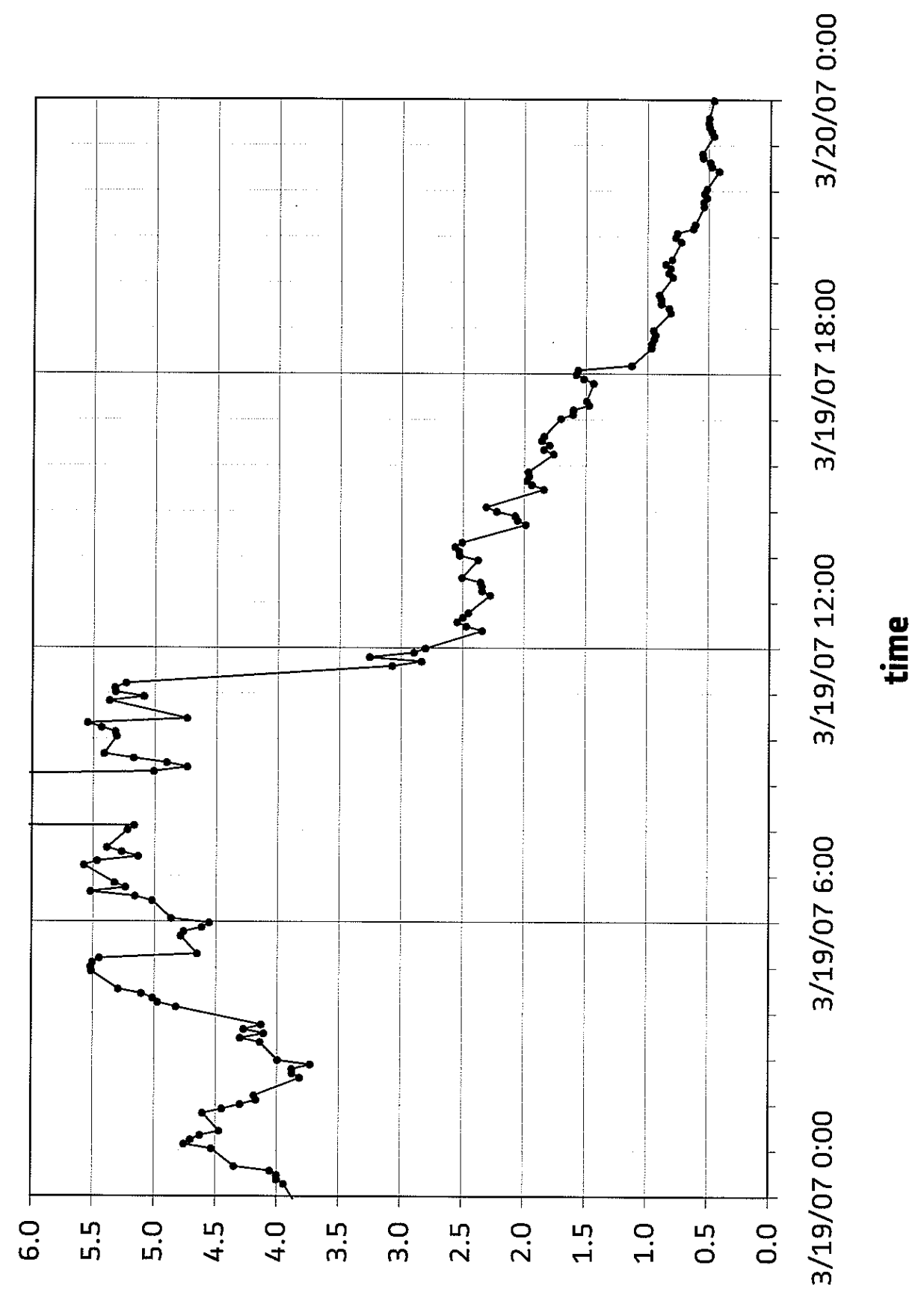

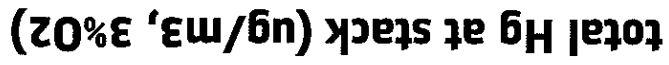




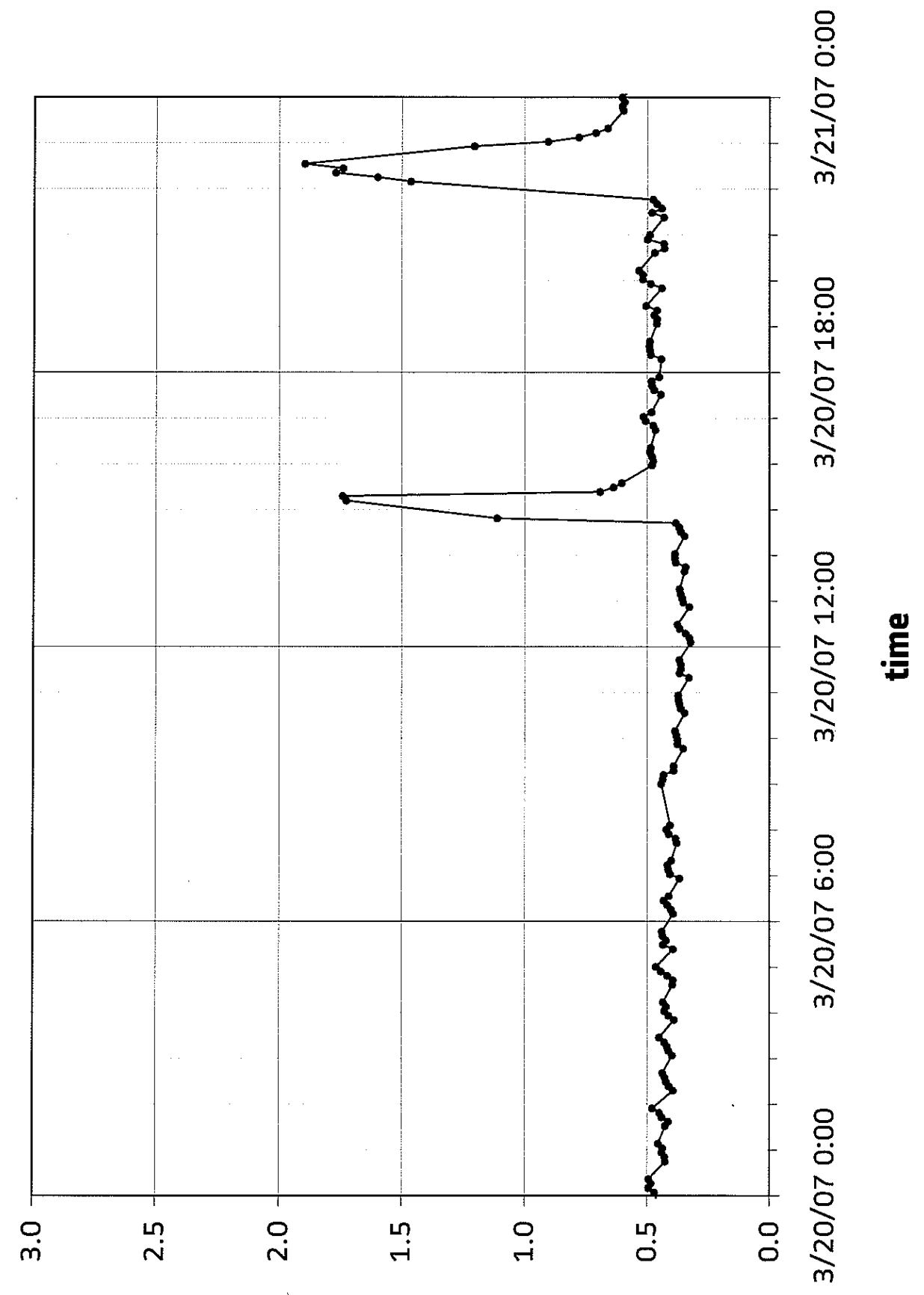

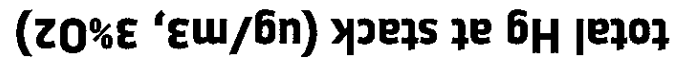




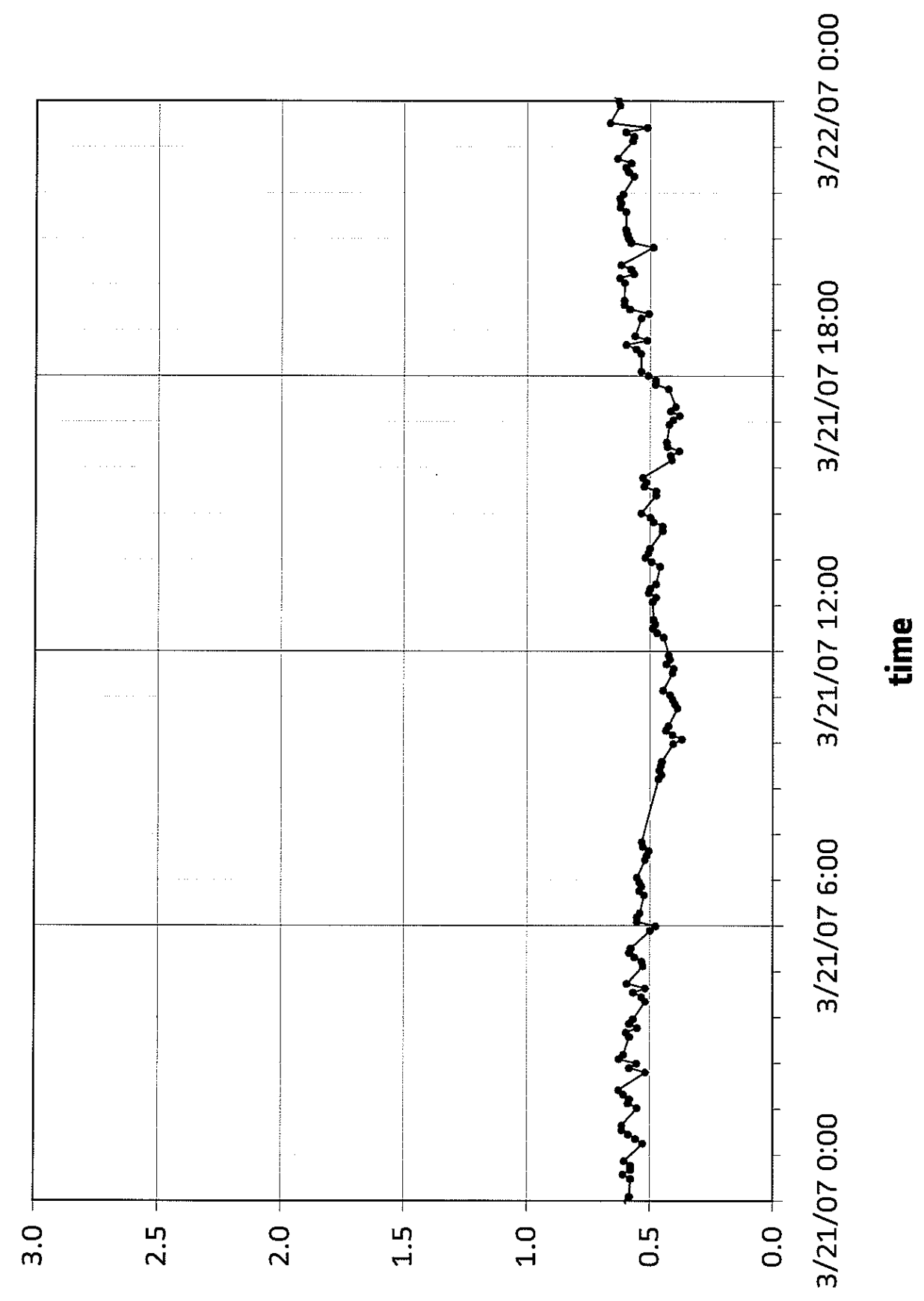

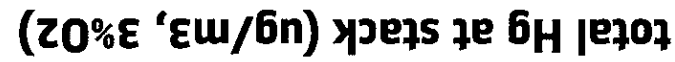




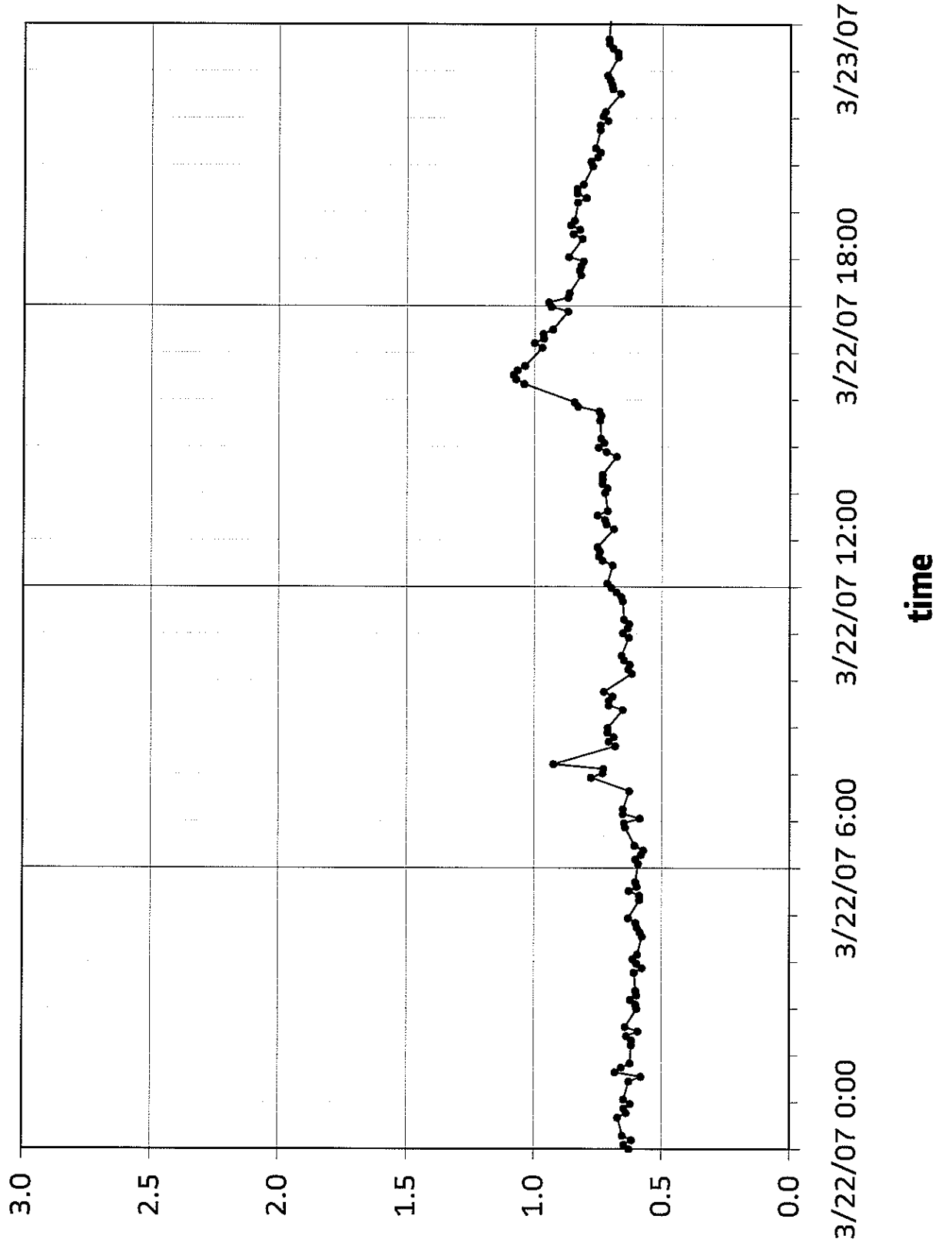

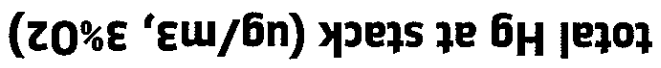




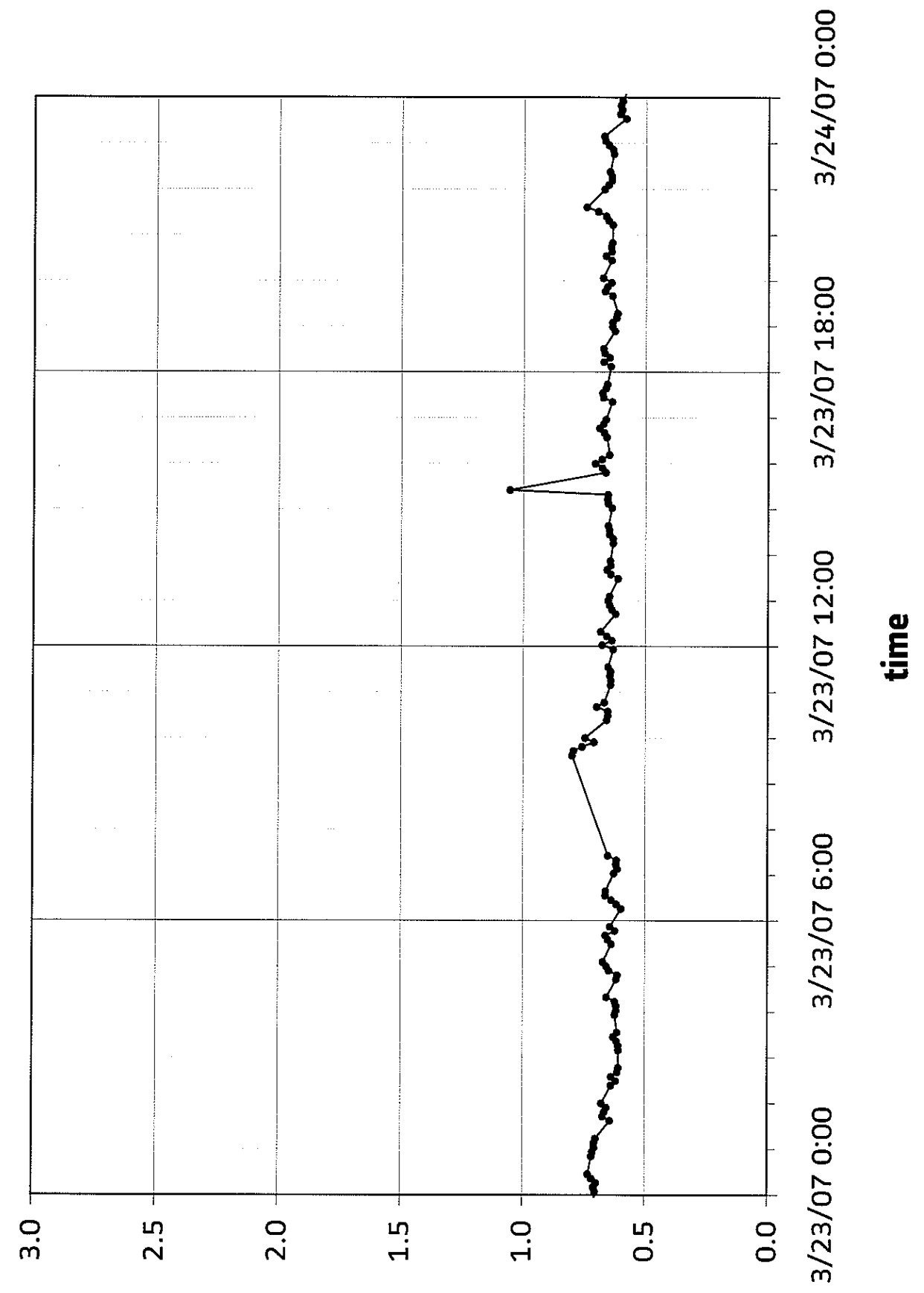

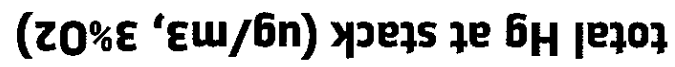




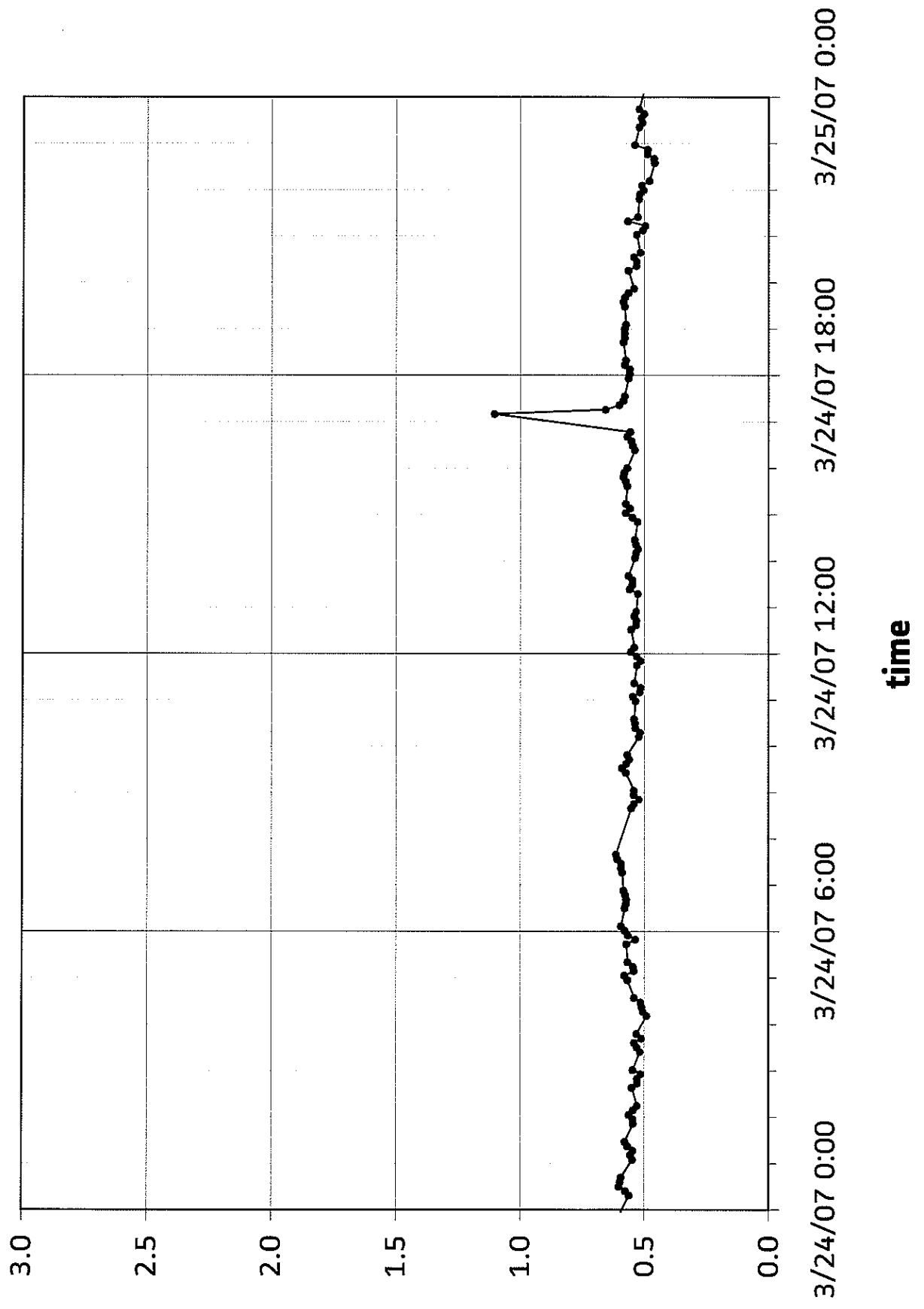

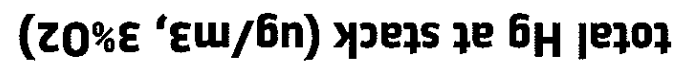




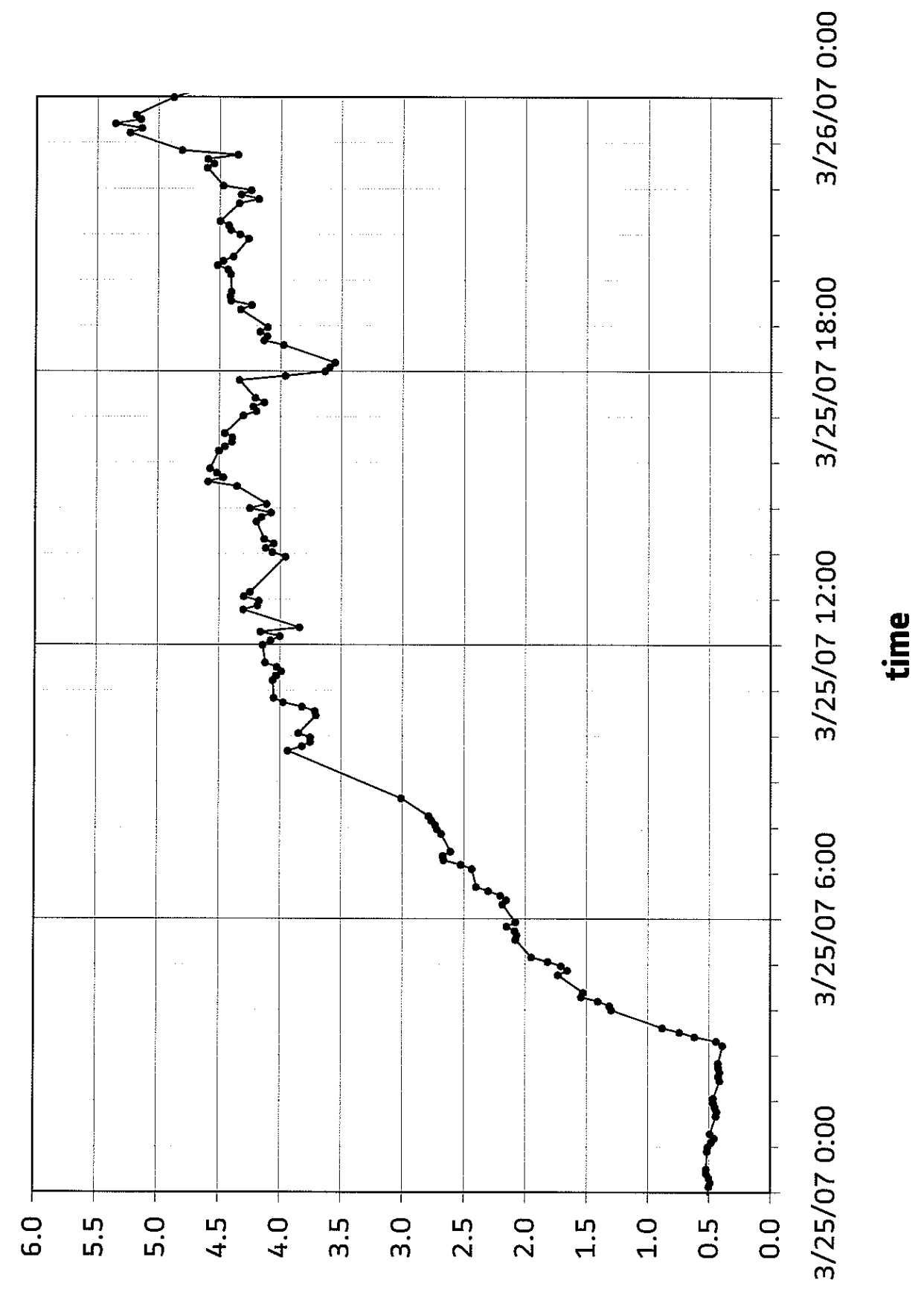

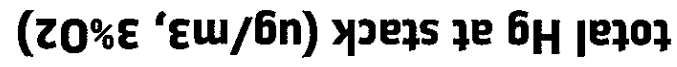




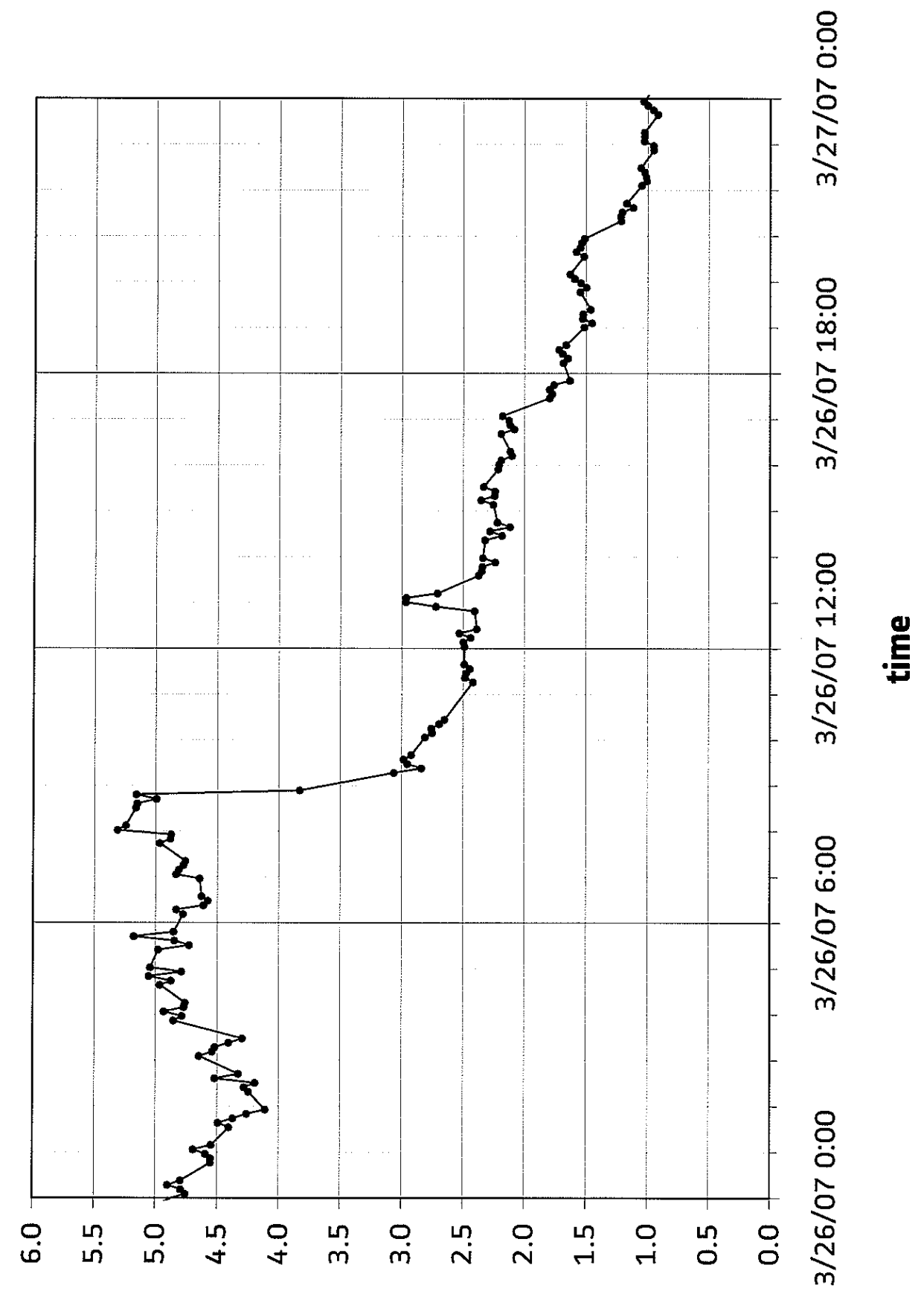

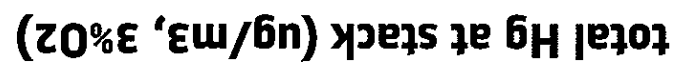




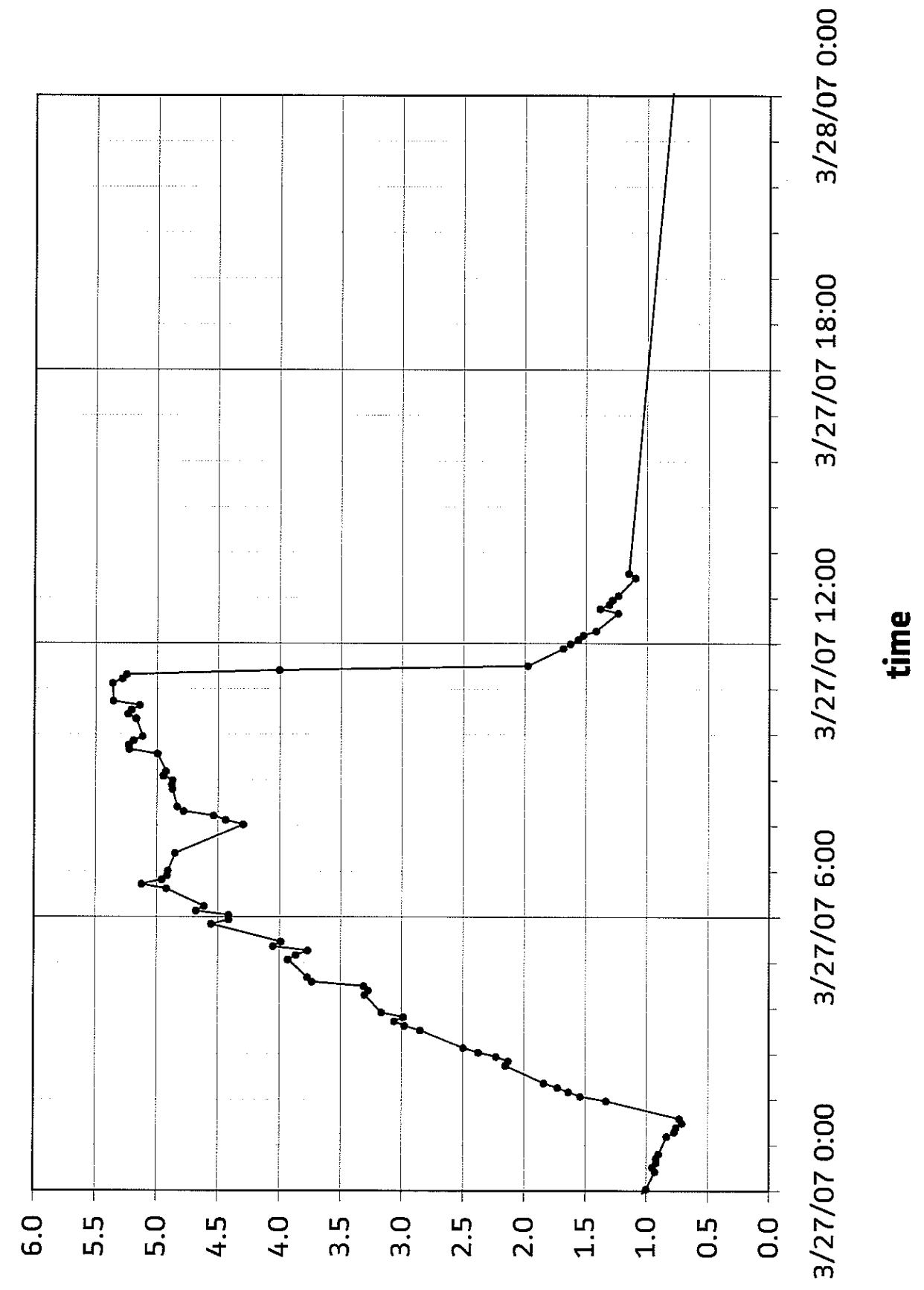

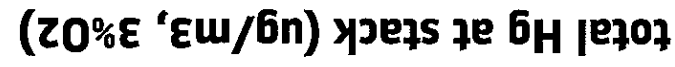




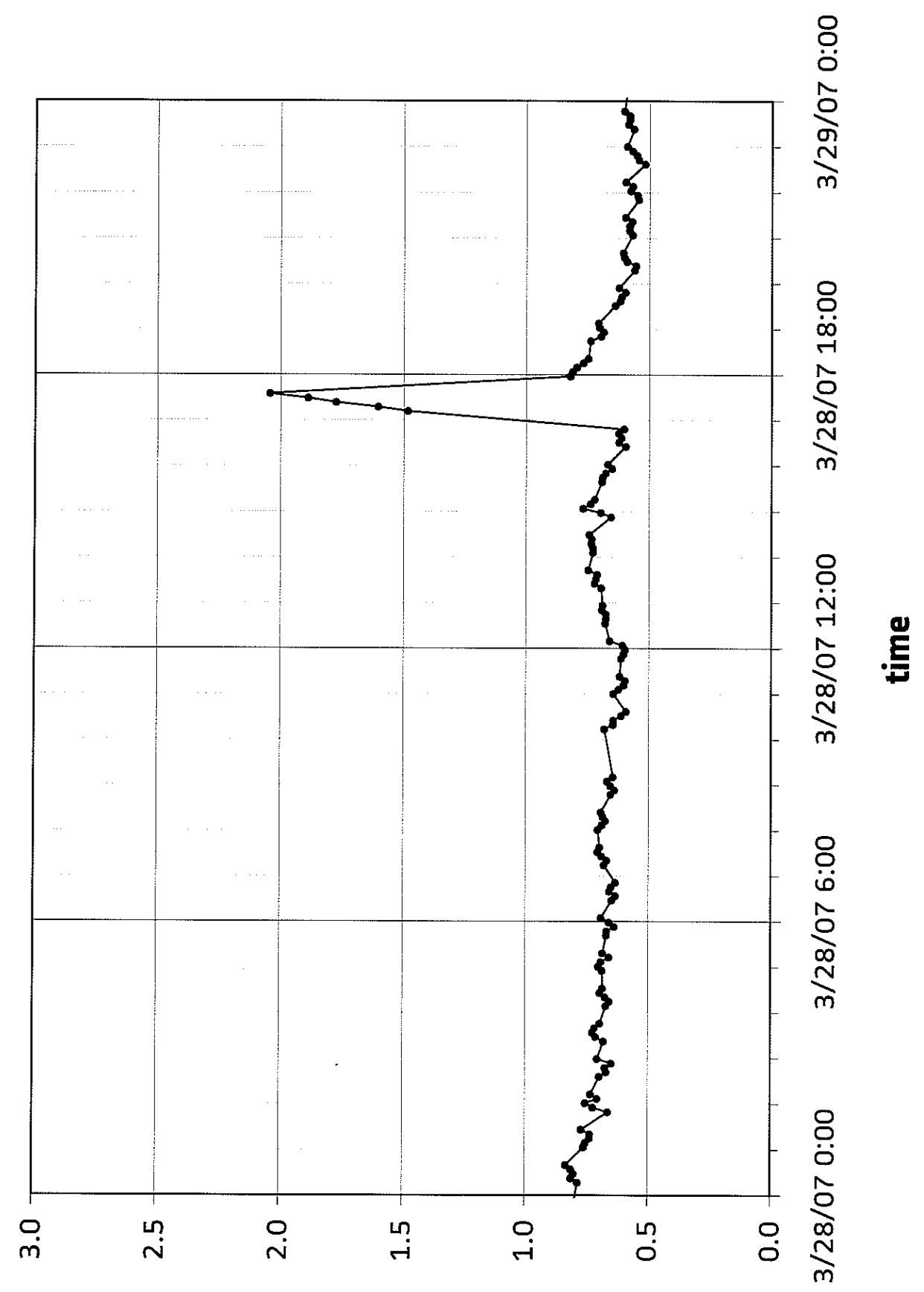

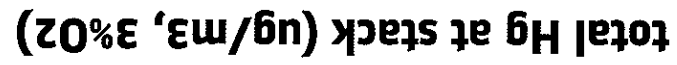




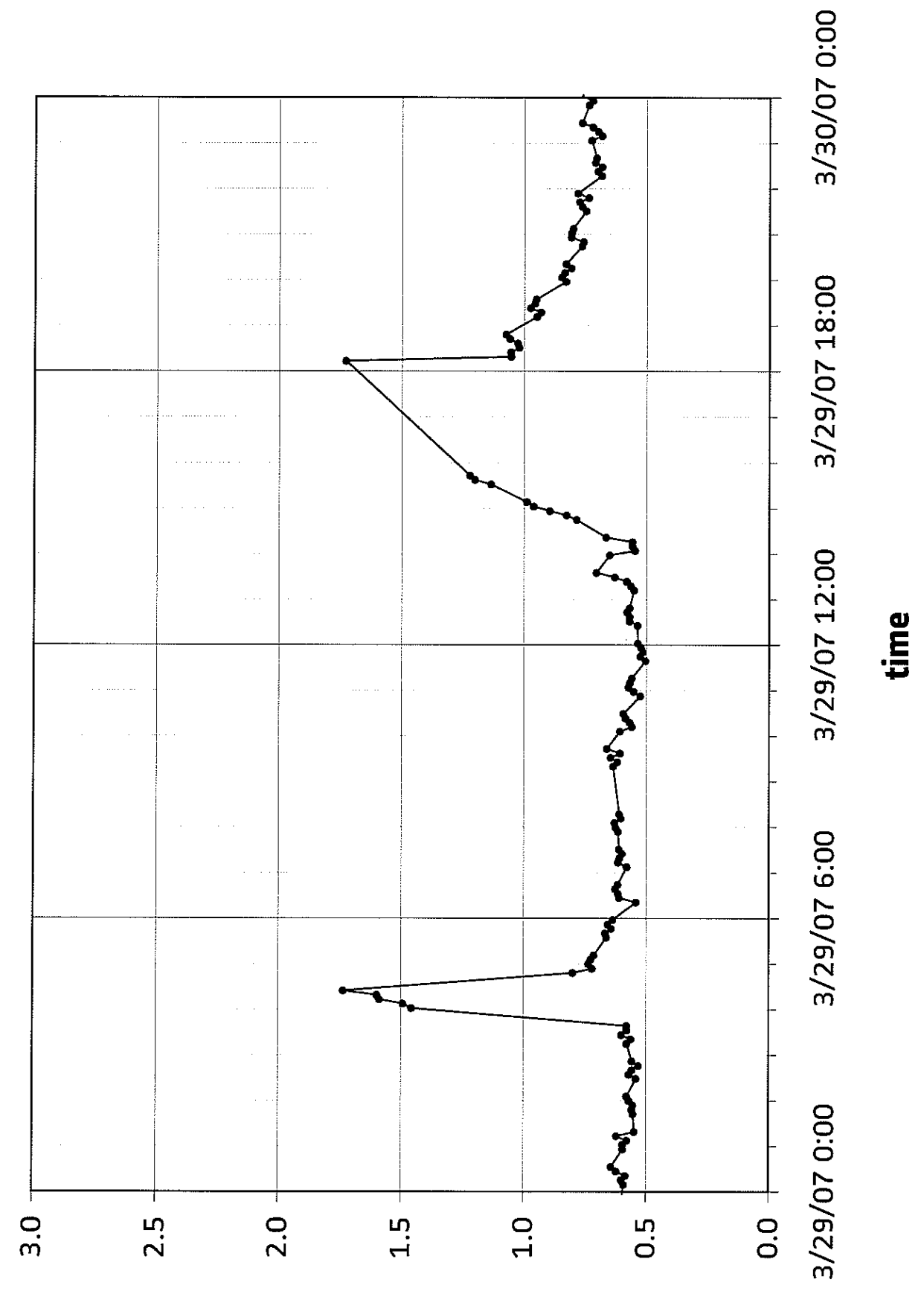

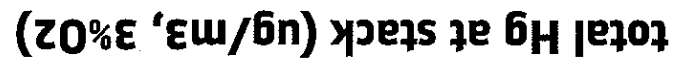




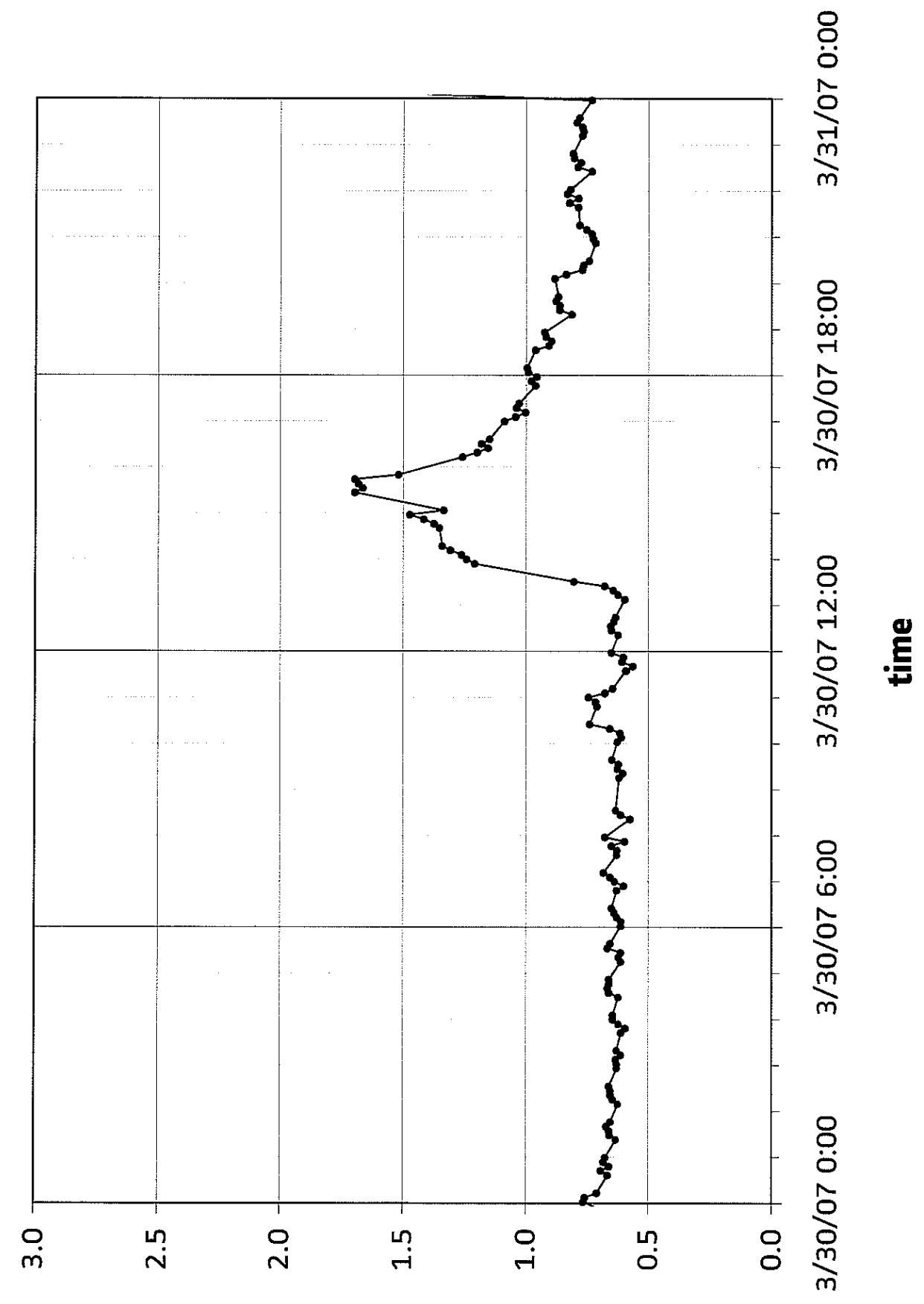

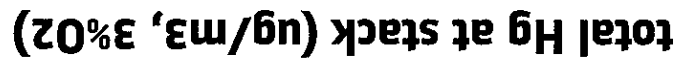




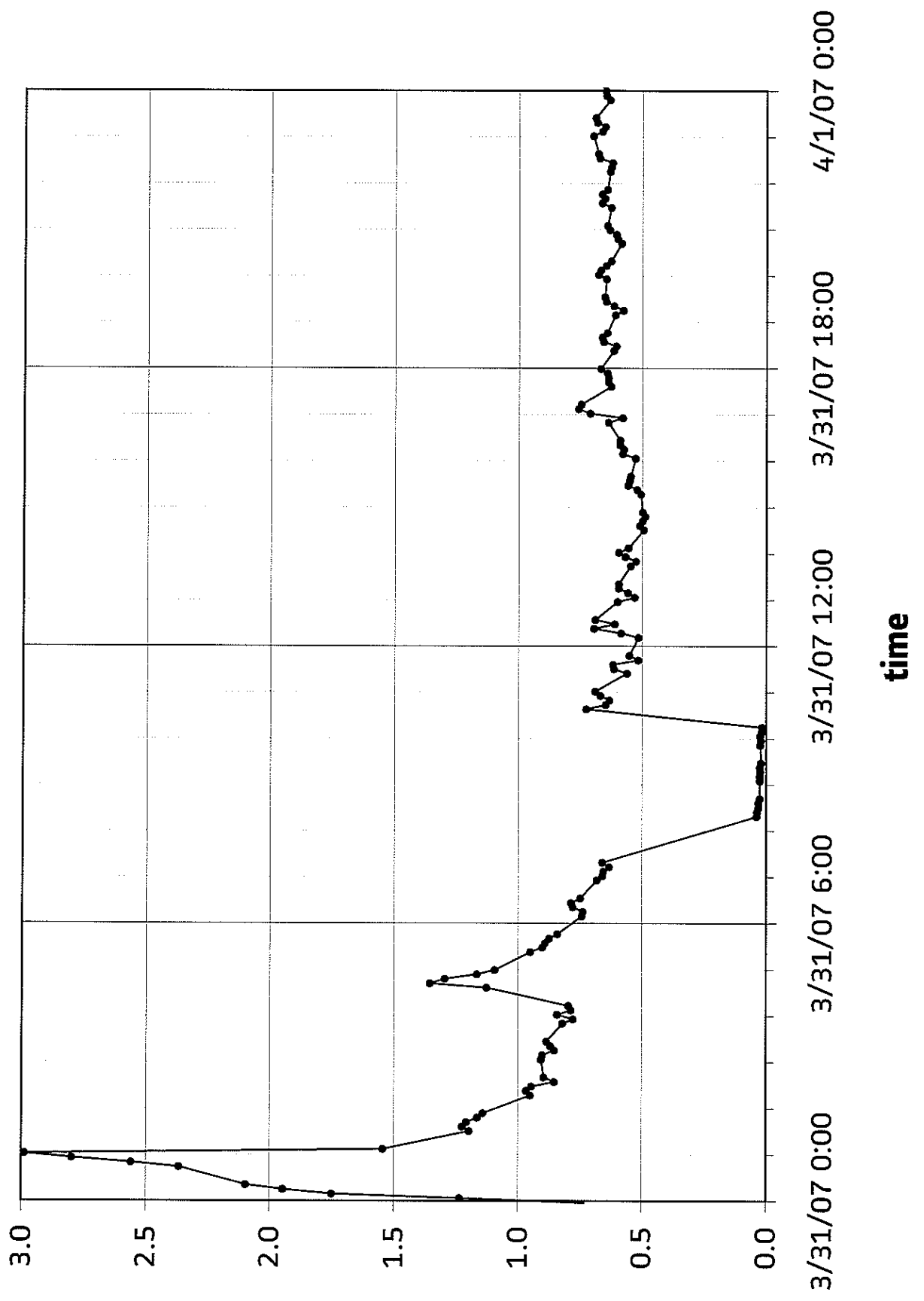

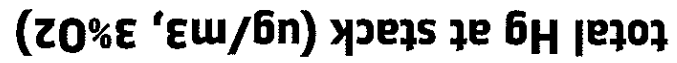




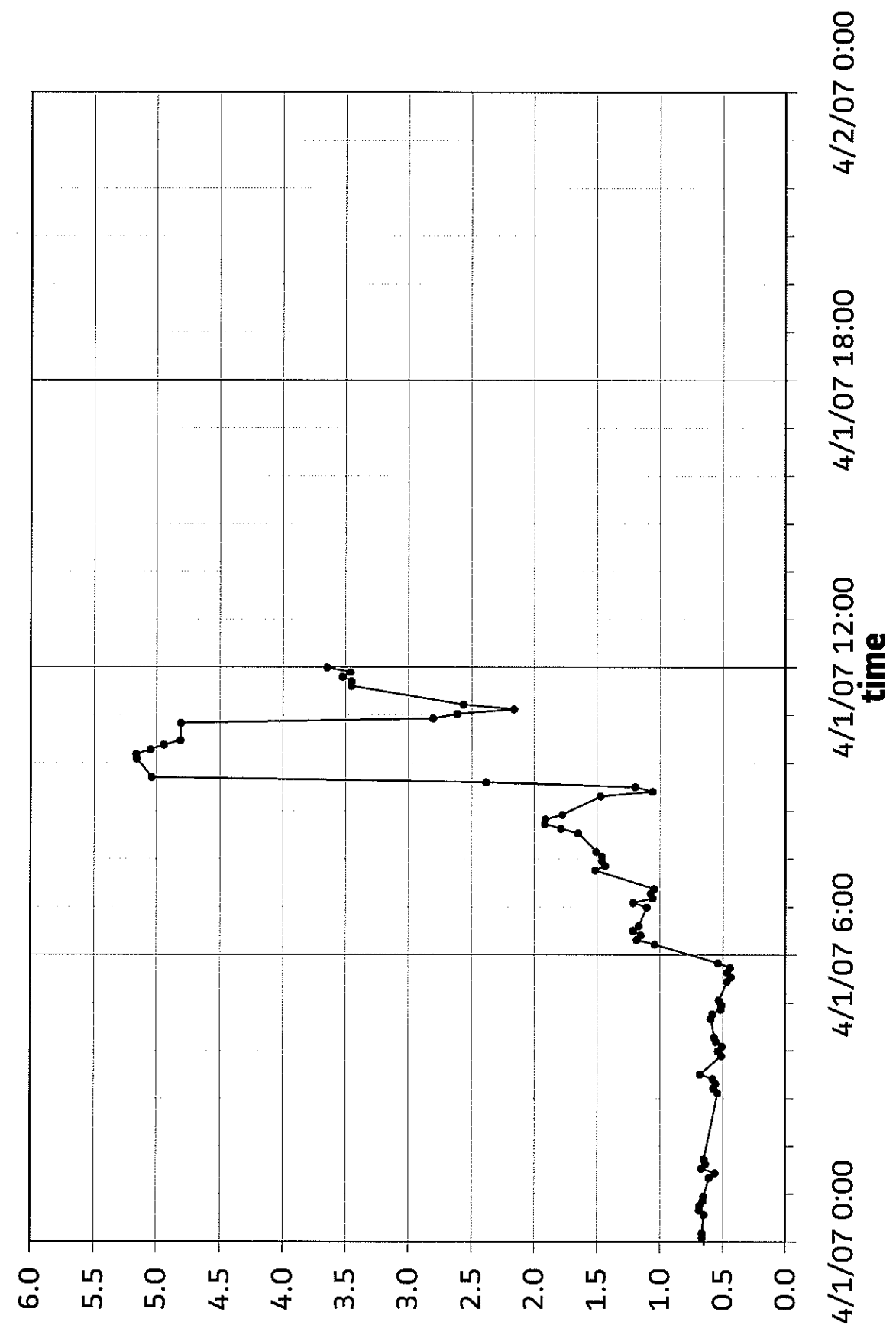

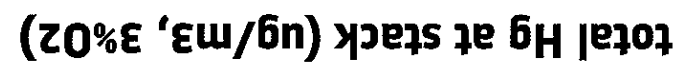




\section{Appendix C Test Schedule, Coal and Ash Analyses}

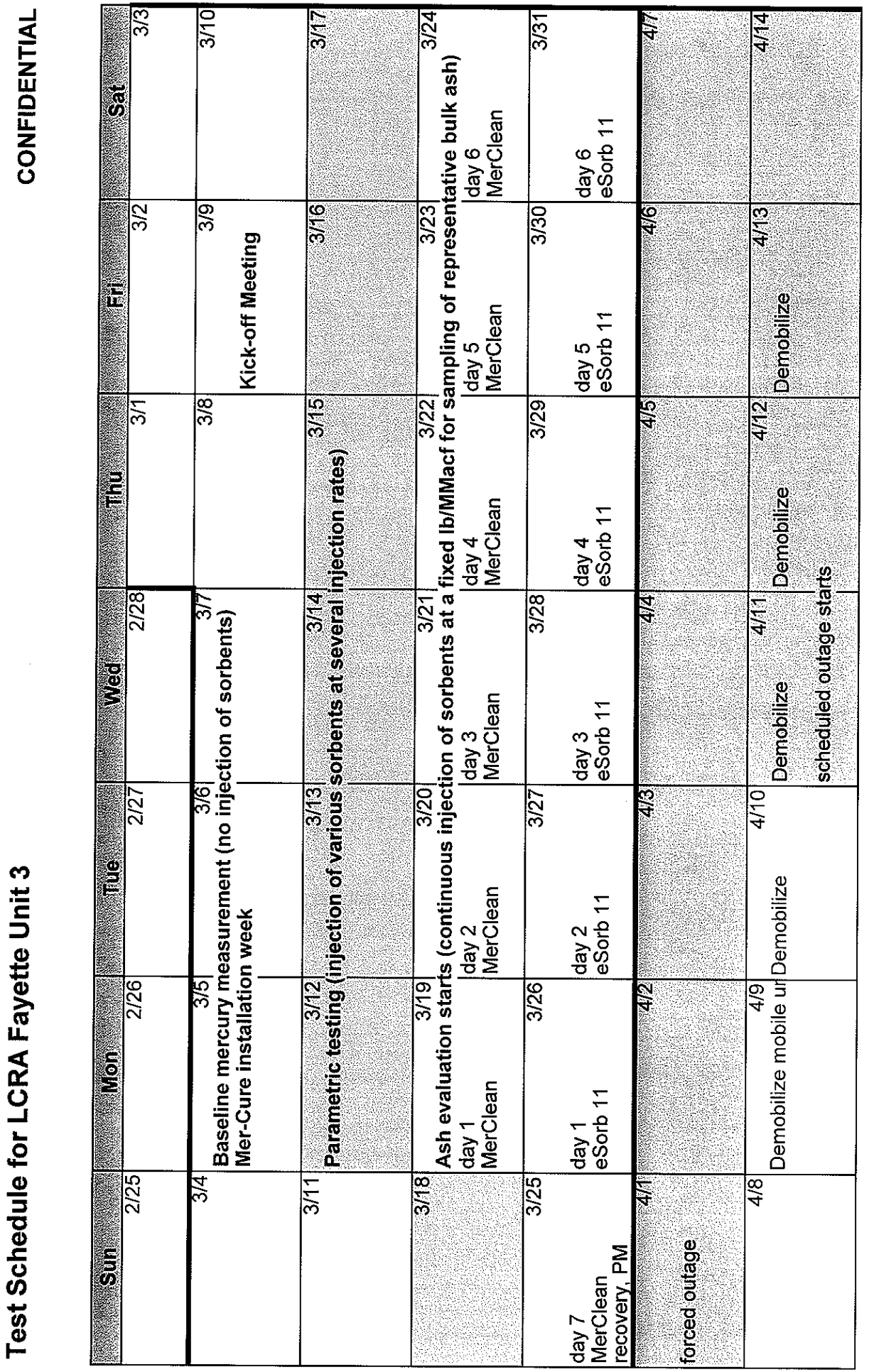




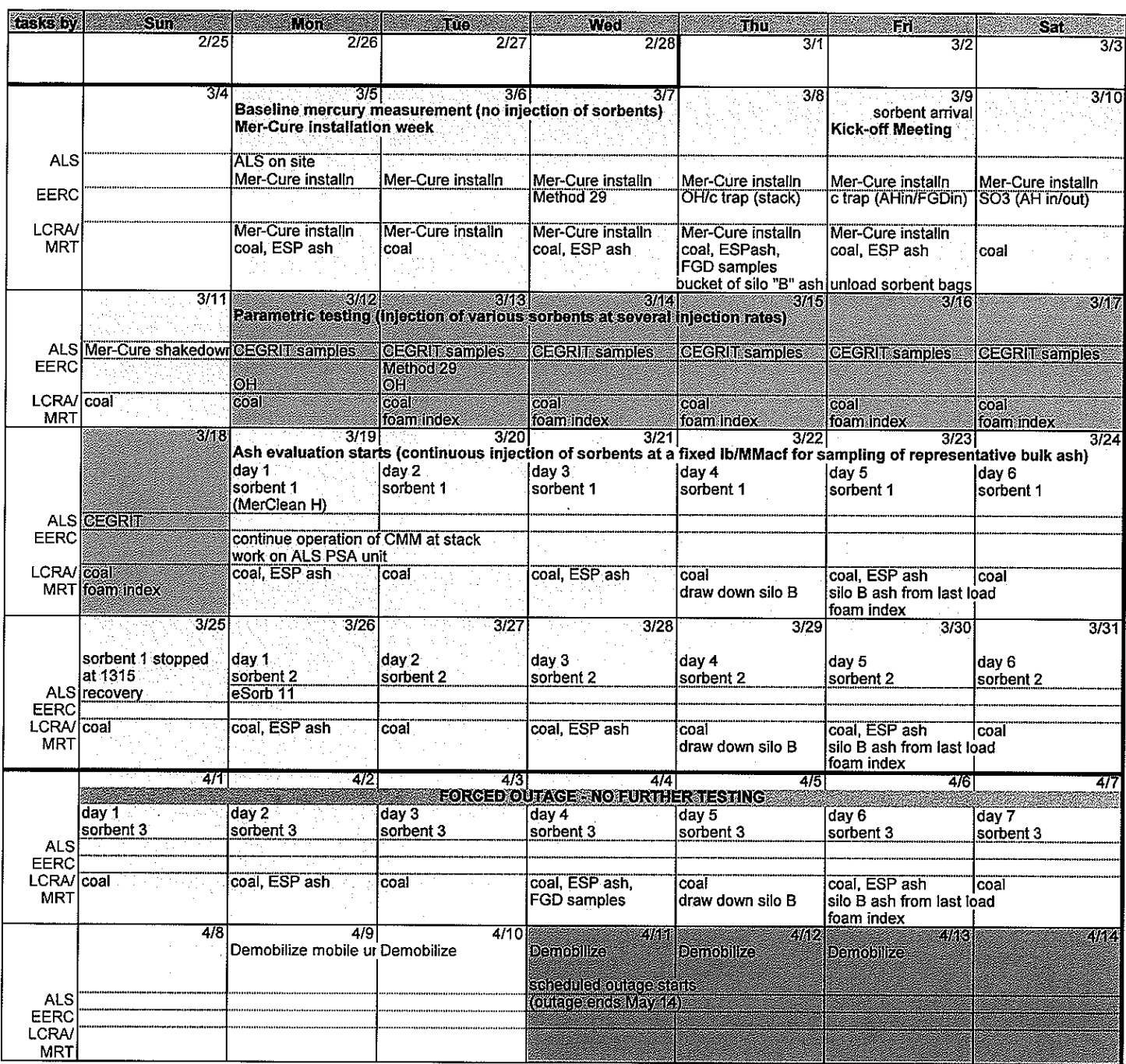

Note: DDuring test period, LCRA will provide control room data on a daily basis, as requested previously.

$\begin{array}{ll}\text { sample type } & \text { sample size } \\ \text { silo B ash } & \text { one 5-gal bucket (from the last load of the day) } \\ \text { ESP ash } & \text { one pint per hopper (six hoppers from North side }\end{array}$

CONFIDENTIAL

ESP ash

coal

(`) FGD samples: limestone slurry gypsum
makeup water one pint per hopper (six hoppers from North side; four hoppers from South) one gal (one pulverizer)

one quart jar (after mill)

one quart jar (after vacuum filter)

one quart jar (upstream reaction vessel) 


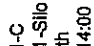

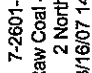

을

究产

$\circ \stackrel{\circ}{\circ}$

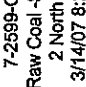

总

商

$0 \stackrel{\circ}{\frac{0}{5}}$

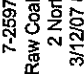

迹要

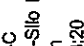

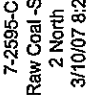

髚

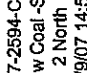

贾

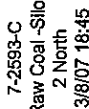

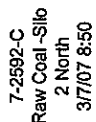

证高

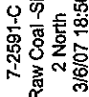

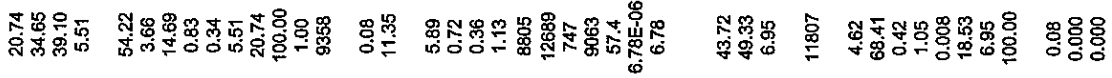

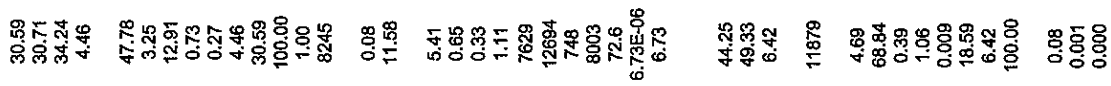

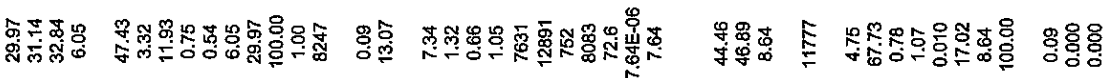

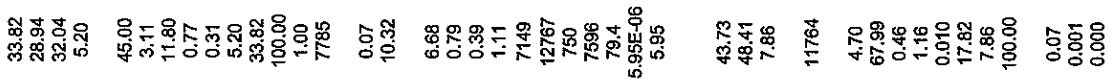

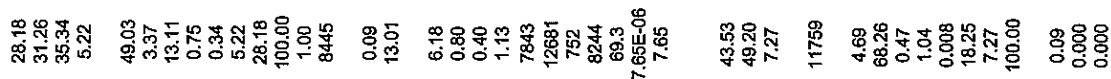

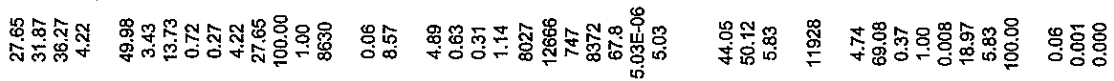

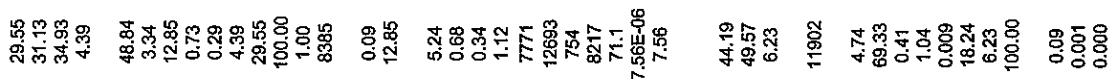

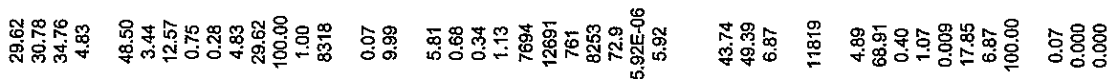

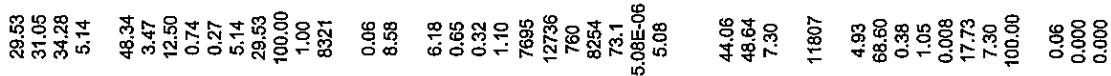

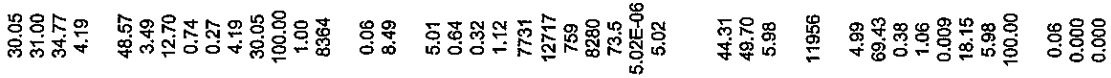

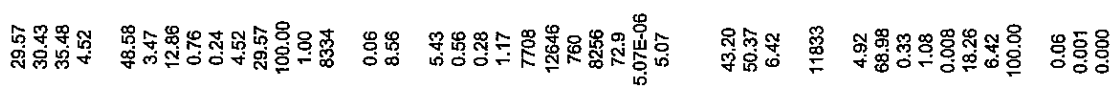

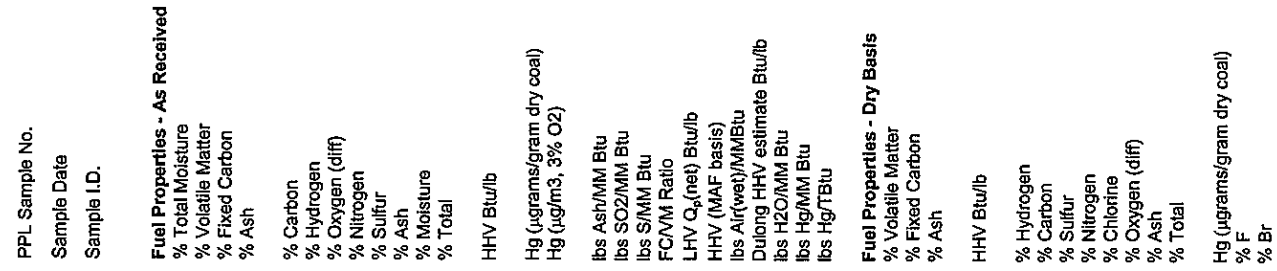

Alstom Power Inc. 


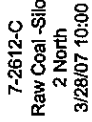

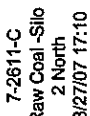

을

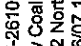

$\therefore$ 造

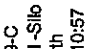

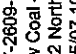

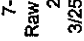

0 응

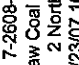

of

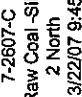

章

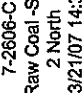

婙

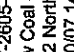

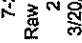

唡

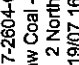

을

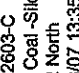

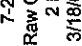

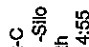

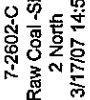

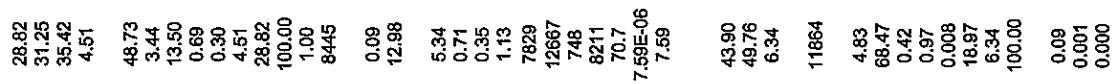

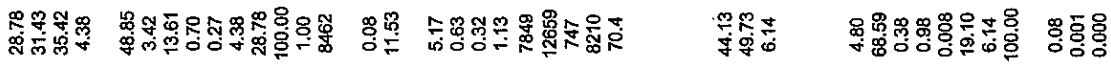

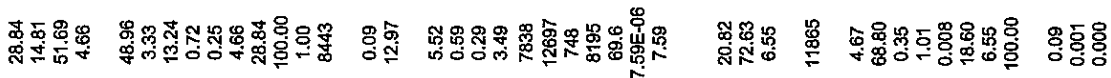

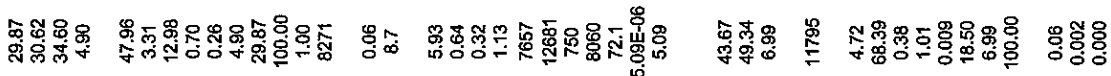

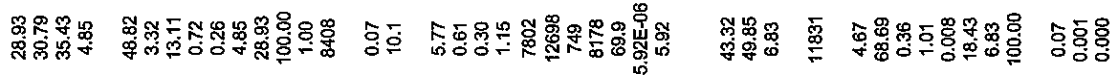

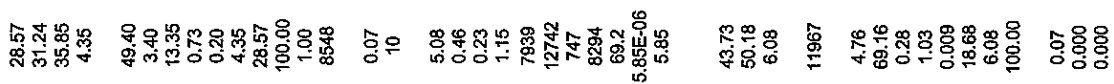

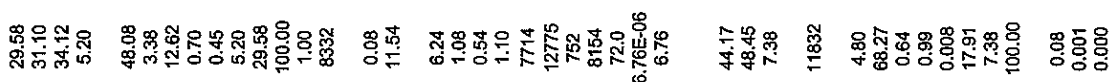

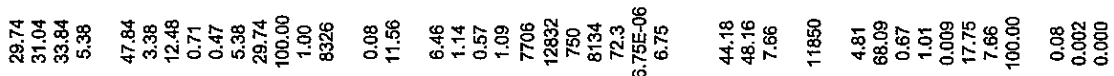

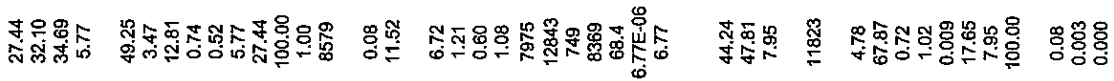

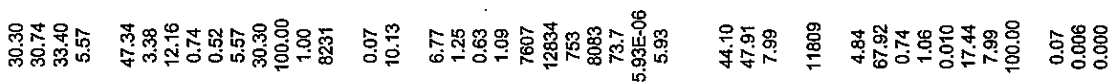

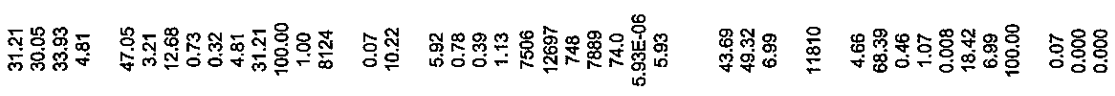

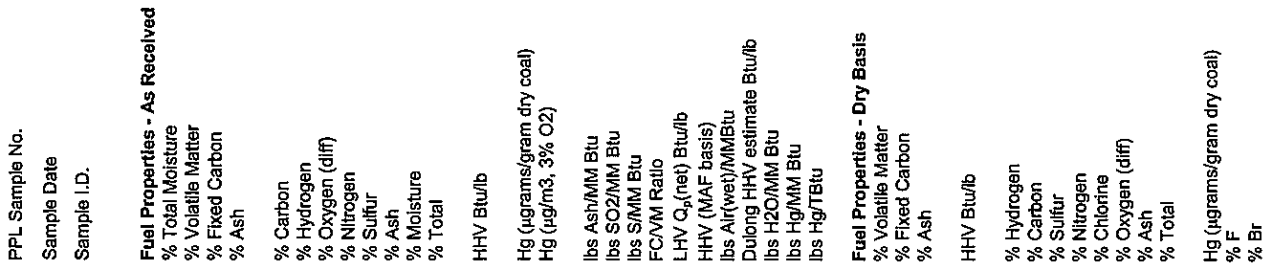

Alstom Power Inc. 


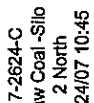

$\wedge$ 造

语

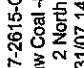

政

은

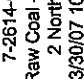

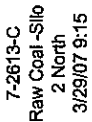

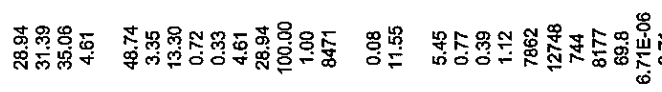

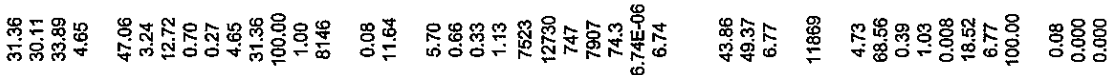

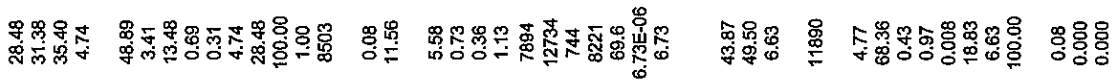

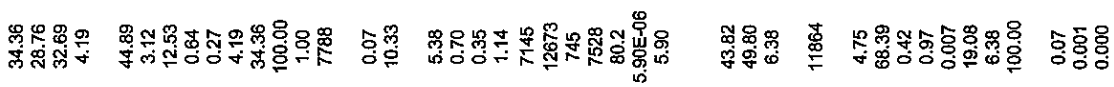

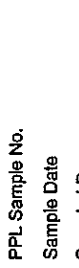
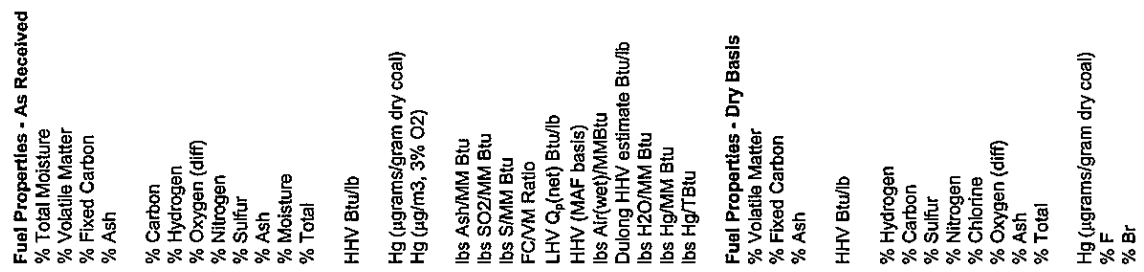

Alstom Power Inc. 


\begin{tabular}{|c|c|c|c|c|c|c|c|}
\hline PPL Sample No. & $7-2591-C$ & $7-2592-C$ & 7-2593-C & $7-2594-C$ & $7-2595-\mathrm{C}$ & $7-2596-C$ & $7-2597-C$ \\
\hline Sample Date & Raw Coal -Silo & Raw Coal -Silo & Raw Coal -Silo & Raw Coal -Silo & Raw Coal -Silo & Raw Coal -Silo & Raw Coal -Silo \\
\hline Sample Date & 2 North & 2 North & 2 North & 2 North & 2 North & 2 North & 2 North \\
\hline Sample I.D. & $3 / 6 / 0718: 50$ & $3 / 7 / 078: 50$ & $3 / 8 / 0718: 45$ & $3 / 9 / 0714: 50$ & $3 / 10 / 078: 20$ & $3 / 11 / 0714: 00$ & $3 / 12 / 078: 50$ \\
\hline \multicolumn{8}{|c|}{ Fuel Properties - As Received } \\
\hline \% Total Moisture & 29.57 & 30.05 & 29.53 & 29.62 & 29.55 & 27.65 & 28.18 \\
\hline$\%$ Volatile Matter & 30.43 & 31.00 & 31.05 & 30.78 & 31.13 & 31.87 & 31.26 \\
\hline$\%$ Fixed Carbon & 35.48 & 34.77 & 34.28 & 34.76 & 34.93 & 36.27 & 35.34 \\
\hline$\%$ Ash & 4.52 & 4.19 & 5.14 & 4.83 & 4.39 & 4.22 & 5.22 \\
\hline HHV Btu/lb & 8334 & 8364 & 8321 & 8318 & 8385 & 8630 & 8445 \\
\hline$\%$ Moisture & 29.57 & 30.05 & 29.53 & 29.62 & 29.55 & 27.65 & 28.18 \\
\hline$\%$ Hydrogen & 3.47 & 3.49 & 3.47 & 3.44 & 3.34 & 3.43 & 3.37 \\
\hline \% Carbon & 48.58 & 48.57 & 48.34 & 48.50 & 48.84 & 49.98 & 49.03 \\
\hline$\%$ Sulfur & 0.24 & 0.27 & 0.27 & 0.28 & 0.29 & 0.27 & 0.34 \\
\hline$\%$ Nitrogen & 0.76 & 0.74 & 0.74 & 0.75 & 0.73 & 0.72 & 0.75 \\
\hline$\%$ Oxygen (diff) & 12.86 & 12.70 & 12.50 & 12.57 & 12.85 & 13.73 & 13.11 \\
\hline$\%$ Ash & 4.52 & 4.19 & 5.14 & 4.83 & 4.39 & 4.22 & 5.22 \\
\hline$\%$ Total & 100.00 & 100.00 & 100.00 & 100.00 & 100.00 & 100.00 & 100.00 \\
\hline Ibs Ash/MM Btu & 5.43 & 5.01 & 6.18 & 5.81 & 5.24 & 4.89 & 6.18 \\
\hline Ibs SO2/MM Btu & 0.56 & 0.64 & 0.65 & 0.68 & 0.68 & 0.63 & 0.80 \\
\hline FC/NM Ratio & 1.17 & 1.12 & 1.10 & 1.13 & 1.12 & 1.14 & 1.13 \\
\hline $\mathrm{LHV} Q_{p}$ (net) Btu/b & 7708 & 7731 & 7695 & 7694 & 7771 & 8027 & 7843 \\
\hline HHV (MAF basis) & 12646 & 12717 & 12736 & 12691 & 12693 & 12666 & 12681 \\
\hline Ibs Air(wet)/MMBtu & 760 & 759 & 760 & 761 & 754 & 747 & 752 \\
\hline Dulong HHV estimate Btu/l & 8256 & 8280 & 8254 & 8253 & 8217 & 8372 & 8244 \\
\hline lbs H2O/MM Btu & 72.9 & 73.5 & 73.1 & 72.9 & 71.1 & 67.8 & 69.3 \\
\hline lbs Hg/MM Btu & 5.07E-06 & 5.02E-06 & 5.08E-06 & 5.92E-06 & 7.56E-06 & $5.03 E-06$ & 7.65E-06 \\
\hline \multicolumn{8}{|l|}{ Fuel Properties - Dry Basis } \\
\hline$\%$ Volatile Matter & 43.20 & 44.31 & 44.06 & 43.74 & 44.19 & 44.05 & 43.53 \\
\hline$\%$ Fixed Carbon & 50.37 & 49.70 & 48.64 & 49.39 & 49.57 & 50.12 & 49.20 \\
\hline$\%$ Ash & 6.42 & 5.98 & 7.30 & 6.87 & 6.23 & 5.83 & 7.27 \\
\hline HHV Btu/lb & 11833 & 11956 & 11807 & 11819 & 11902 & 11928 & 11759 \\
\hline$\%$ Hydrogen & 4.92 & 4.99 & 4.93 & 4.89 & 4.74 & 4.74 & 4.69 \\
\hline$\%$ Carbon & 68.98 & 69.43 & 68.60 & 68.91 & 69.33 & 69.08 & 68.26 \\
\hline$\%$ Sulfur & 0.33 & 0.38 & 0.38 & 0.40 & 0.41 & 0.37 & 0.47 \\
\hline$\%$ Nitrogen & 1.08 & 1.06 & 1.05 & 1.07 & 1.04 & 1.00 & 1.04 \\
\hline$\%$ Chlorine & 0.008 & 0.009 & 0.008 & 0.009 & 0.009 & 0.008 & 0.008 \\
\hline$\%$ Oxygen (diff) & 18.26 & 18.15 & 17.73 & 17.85 & 18.24 & 18.97 & 18.25 \\
\hline$\%$ Ash & 6.42 & 5.98 & 7.30 & 6.87 & 6.23 & 5.83 & 7.27 \\
\hline$\%$ Total & 100.00 & 100.00 & 100.00 & 100.00 & 100.00 & 100.00 & 100.00 \\
\hline $\mathrm{Hg}$ ( $\mu$ grams/gram dry coal) & 0.06 & 0.06 & 0.06 & 0.07 & 0.09 & 0.06 & 0.09 \\
\hline$\% \mathrm{~F}$ & 0.001 & 0.000 & 0.000 & 0.000 & 0.001 & 0.001 & 0.000 \\
\hline$\% \mathrm{Br}$ & 0.000 & 0.000 & 0.000 & 0.000 & 0.000 & 0.000 & 0.000 \\
\hline
\end{tabular}




\begin{tabular}{|c|c|c|c|c|c|c|c|}
\hline PPL Sample No. & $7-2598-C$ & $7-2599-C$ & $7-2600-C$ & $7-2601-C$ & $7-2602-C$ & $7-2603-C$ & $7-2604-C$ \\
\hline Sample Date & Raw Coal -Silo & Raw Coal -Silo & Raw Coal -Silo & Raw Coal -Silo & Raw Coal -Silo & Raw Coal -Silo & Raw Coal -Silc \\
\hline . Sample Date & 2 North & 2 North & 2 North & 2 North & 2 North & 2 North & 2 North \\
\hline Sample I.D. & $3 / 13 / 078: 30$ & $3 / 14 / 078: 20$ & $3 / 15 / 0716: 25$ & $3 / 16 / 0714: 00$ & $3 / 17 / 0714: 55$ & $3 / 18 / 0713: 35$ & $3 / 19 / 0716: 37$ \\
\hline \multicolumn{8}{|l|}{ Fuel Properties - As Rece } \\
\hline \% Total Moisture & 33.82 & 29.97 & 30.59 & 20.74 & 31.21 & 30.30 & 27.44 \\
\hline$\%$ Volatile Matter & 28.94 & 31.14 & 30.71 & 34.65 & 30.05 & 30.74 & 32.10 \\
\hline \% Fixed Carbon & 32.04 & 32.84 & 34.24 & 39.10 & 33.93 & 33.40 & 34.69 \\
\hline$\%$ Ash & 5.20 & 6.05 & 4.46 & 5.51 & 4.81 & 5.57 & 5.77 \\
\hline HHV Btu/lb & 7785 & 8247 & 8245 & 9358 & 8124 & 8231 & 8579 \\
\hline$\%$ Moisture & 33.82 & 29.97 & 30.59 & 20.74 & 31.21 & 30.30 & 27.44 \\
\hline$\%$ Hydrogen & 3.11 & 3.32 & 3.25 & 3.66 & 3.21 & 3.38 & 3.47 \\
\hline \% Carbon & 45.00 & 47.43 & 47.78 & 54.22 & 47.05 & 47.34 & 49.25 \\
\hline$\%$ Sulfur & 0.31 & 0.54 & 0.27 & 0.34 & 0.32 & 0.52 & 0.52 \\
\hline$\%$ Nitrogen & 0.77 & 0.75 & 0.73 & 0.83 & 0.73 & 0.74 & 0.74 \\
\hline \% Oxygen (diff) & 11.80 & 11.93 & 12.91 & 14.69 & 12.68 & 12.16 & 12.81 \\
\hline$\%$ Ash & 5.20 & 6.05 & 4.46 & 5.51 & 4.81 & 5.57 & 5.77 \\
\hline$\%$ Total & 100.00 & 100.00 & 100.00 & 100.00 & 100.00 & 100.00 & 100.00 \\
\hline Ibs Ash/MM Btu & 6.68 & 7.34 & 5.41 & 5.89 & 5.92 & 6.77 & 6.72 \\
\hline Ibs SO2/MM Btu & 0.79 & 1.32 & 0.65 & 0.72 & 0.78 & 1.25 & 1.21 \\
\hline FC/VM Ratio & 1.11 & 1.05 & 1.11 & 1.13 & 1.13 & 1.09 & 1.08 \\
\hline LHV $Q_{p}(n e t) B t u / l b$ & 7149 & 7631 & 7629 & 8805 & 7506 & 7607 & 7975 \\
\hline HHV (MAF basis) & 12767 & 12891 & 12694 & 12689 & 12697 & 12834 & 12843 \\
\hline Ibs Air(wet)/MMBtu & 750 & 752 & 748 & 747 & 748 & 753 & 749 \\
\hline Dulong HHV estimate Btu/l & 7596 & 8083 & 8003 & 9063 & 7889 & 8083 & 8369 \\
\hline Ibs H2O/MM Btu & 79.4 & 72.6 & 72.6 & 57.4 & 74.0 & 73.7 & 68.4 \\
\hline Ibs Hg/MM Btu & 5.95E-06 & 7.64E-06 & $6.73 \mathrm{E}-06$ & 6.78E-06 & 5.93E-06 & 5.93E-06 & 6.77E-06 \\
\hline \multicolumn{8}{|l|}{ Fuel Properties - Dry Bas } \\
\hline \% Volatile Matter & 43.73 & 44.46 & 44.25 & 43.72 & 43.69 & 44.10 & 44.24 \\
\hline$\%$ Fixed Carbon & 48.41 & 46.89 & 49.33 & 49.33 & 49.32 & 47.91 & 47.81 \\
\hline$\%$ Ash & 7.86 & 8.64 & 6.42 & 6.95 & 6.99 & 7.99 & 7.95 \\
\hline HHV Btu/lb & 11764 & 11777 & 11879 & 11807 & 11810 & 11809 & 11823 \\
\hline$\%$ Hydrogen & 4.70 & 4.75 & 4.69 & 4.62 & 4.66 & 4.84 & 4.78 \\
\hline \% Carbon & 67.99 & 67.73 & 68.84 & 68.41 & 68.39 & 67.92 & 67.87 \\
\hline$\%$ Sulfur & 0.46 & 0.78 & 0.39 & 0.42 & 0.46 & 0.74 & 0.72 \\
\hline$\%$ Nitrogen & 1.16 & 1.07 & 1.06 & 1.05 & 1.07 & 1.06 & 1.02 \\
\hline$\%$ Chlorine & 0.010 & 0.010 & 0.009 & 0.008 & 0.008 & 0.010 & 0.009 \\
\hline$\%$ Oxygen (diff) & 17.82 & 17.02 & 18.59 & 18.53 & 18.42 & 17.44 & 17.65 \\
\hline$\%$ Ash & 7.86 & 8.64 & 6.42 & 6.95 & 6.99 & 7.99 & 7.95 \\
\hline$\%$ Total & 100.00 & 100.00 & 100.00 & 100.00 & 100.00 & 100.00 & 100.00 \\
\hline Hg ( $\mu$ grams/gram dry coal) & 0.07 & 0.09 & 0.08 & 0.08 & 0.07 & 0.07 & 0.08 \\
\hline$\% \mathrm{~F}$ & 0.001 & 0.000 & 0.001 & 0.000 & 0.000 & 0.006 & 0.003 \\
\hline$\% \mathrm{Br}$ & 0.000 & 0.000 & 0.000 & 0.000 & 0.000 & 0.000 & 0.000 \\
\hline
\end{tabular}




\begin{tabular}{|c|c|c|c|c|c|c|c|}
\hline PPL Sample No. & 7-2605-C & $7-2606-C$ & $7-2607-\mathrm{C}$ & 7-2608-C & $7-2609-C$ & $7-2610-C$ & 7-2611-C \\
\hline Sample Date & Raw Coal -Silo & Raw Coal -Silo & Raw Coal-Silo & Raw Coal -Silo & Raw Coal-Silo & Raw Coal-Silo & Raw Coal -Silo \\
\hline Sample Date & 2 North & 2 North & 2 North & 2 North & 2 North & 2 North & 2 North \\
\hline Sample I.D. & $3 / 20 / 0714: 20$ & $3 / 21 / 0714: 35$ & $3 / 22 / 079: 45$ & $3 / 23 / 0716: 00$ & $3 / 25 / 0710: 57$ & $3 / 26 / 07 \quad 10: 45$ & $3 / 27 / 0717: 10$ \\
\hline \multicolumn{8}{|l|}{ Fuel Properties - As Rece } \\
\hline$\%$ Total Moisture & 29.74 & 29.58 & 28.57 & 28.93 & 29.87 & 28.84 & 28.78 \\
\hline$\%$ Volatile Matter & 31.04 & 31.10 & 31.24 & 30.79 & 30.62 & 14.81 & 31.43 \\
\hline$\%$ Fixed Carbon & 33.84 & 34.12 & 35.85 & 35.43 & 34.60 & 51.69 & 35.42 \\
\hline$\%$ Ash & 5.38 & 5.20 & 4.35 & 4.85 & 4.90 & 4.66 & 4.38 \\
\hline HHV Btu/lb & 8326 & 8332 & 8548 & 8408 & 8271 & 8443 & 8462 \\
\hline$\%$ Moisture & 29.74 & 29.58 & 28.57 & 28.93 & 29.87 & 28.84 & 28.78 \\
\hline$\%$ Hydrogen & 3.38 & 3.38 & 3.40 & 3.32 & 3.31 & 3.33 & 3.42 \\
\hline \% Carbon & 47.84 & 48.08 & 49.40 & 48.82 & 47.96 & 48.96 & 48.85 \\
\hline$\%$ Sulfur & 0.47 & 0.45 & 0.20 & 0.26 & 0.26 & 0.25 & 0.27 \\
\hline$\%$ Nitrogen & 0.71 & 0.70 & 0.73 & 0.72 & 0.70 & 0.72 & 0.70 \\
\hline$\%$ Oxygen (diff) & 12.48 & 12.62 & 13.35 & 13.11 & 12.98 & 13.24 & 13.61 \\
\hline$\%$ Ash & 5.38 & 5.20 & 4.35 & 4.85 & 4.90 & 4.66 & 4.38 \\
\hline$\%$ Total & 100.00 & 100.00 & 100.00 & 100.00 & 100.00 & 100.00 & 100.00 \\
\hline lbs Ash/MM Btu & 6.46 & 6.24 & 5.08 & 5.77 & 5.93 & 5.52 & 5.17 \\
\hline lbs SO2/MM Btu & 1.14 & 1.08 & 0.46 & 0.61 & 0.64 & 0.59 & 0.63 \\
\hline FCNM Ratio & 1.09 & 1.10 & 1.15 & 1.15 & 1.13 & 3.49 & 1.13 \\
\hline LHV $Q_{p}(n e t) B t u / l b$ & 7706 & 7714 & 7939 & 7802 & 7657 & 7838 & 7849 \\
\hline HHV (MAF basis) & 12832 & 12775 & 12742 & 12698 & 12681 & 12697 & 12659 \\
\hline lbs Air(wet)/MMBtu & 750 & 752 & 747 & 749 & 750 & 748 & 747 \\
\hline Dulong HHV estimate Btu/l & 8134 & 8154 & 8294 & 8178 & 8060 & 8195 & 8210 \\
\hline Ibs H2O/MM Btu & 72.3 & 72.0 & 69.2 & 69.9 & 72.1 & 69.6 & 70.4 \\
\hline Ibs Hg/MM Btu & $6.75 \mathrm{E}-06$ & $6.76 \mathrm{E}-06$ & $5.85 \mathrm{E}-06$ & 5.92E-06 & 5.09E-06 & $7.59 \mathrm{E}-06$ & \#REF! \\
\hline \multicolumn{8}{|l|}{ Fuel Properties - Dry Bas } \\
\hline$\%$ Volatile Matter & 44.18 & 44.17 & 43.73 & 43.32 & 43.67 & 20.82 & 44.13 \\
\hline$\%$ Fixed Carbon & 48.16 & 48.45 & 50.18 & 49.85 & 49.34 & 72.63 & 49.73 \\
\hline$\%$ Ash & 7.66 & 7.38 & 6.08 & 6.83 & 6.99 & 6.55 & 6.14 \\
\hline HHV Btu/lb & 11850 & 11832 & 11967 & 11831 & 11795 & 11865 & \#REF! \\
\hline$\%$ Hydrogen & 4.81 & 4.80 & 4.76 & 4.67 & 4.72 & 4.67 & 4.80 \\
\hline$\%$ Carbon & 68.09 & 68.27 & 69.16 & 68.69 & 68.39 & 68.80 & 68.59 \\
\hline$\%$ Sulfur & 0.67 & 0.64 & 0.28 & 0.36 & 0.38 & 0.35 & 0.38 \\
\hline$\%$ Nitrogen & 1.01 & 0.99 & 1.03 & 1.01 & 1.01 & 1.01 & 0.98 \\
\hline$\%$ Chlorine & 0.009 & 0.008 & 0.009 & 0.008 & 0.009 & 0.008 & 0.008 \\
\hline$\%$ Oxygen (diff) & 17.75 & 17.91 & 18.68 & 18.43 & 18.50 & 18.60 & 19.10 \\
\hline$\%$ Ash & 7.66 & 7.38 & 6.08 & 6.83 & 6.99 & 6.55 & 6.14 \\
\hline$\%$ Total & 100.00 & 100.00 & 100.00 & 100.00 & 100.00 & 100.00 & 100.00 \\
\hline $\mathrm{Hg}$ ( $\mu$ grams/gram dry coal) & 0.08 & 0.08 & 0.07 & 0.07 & 0.06 & 0.09 & 0.08 \\
\hline$\% \mathrm{~F}$ & 0.002 & 0.001 & 0.000 & 0.001 & 0.002 & 0.001 & 0.001 \\
\hline$\% \mathrm{Br}$ & 0.000 & 0.000 & 0.000 & 0.000 & 0.000 & 0.000 & 0.000 \\
\hline
\end{tabular}




\begin{tabular}{|c|c|c|c|c|c|}
\hline PPL Sample No. & $7-2612-\mathrm{C}$ & $7-2613-C$ & 7-2614-C & $7-2615-\mathrm{C}$ & 7-2624-C \\
\hline & Raw Coal -Silo & Raw Coal -Silo & Raw Coal -Silo & Raw Coal -Silo & Raw CoaI -Silo \\
\hline Sample Date & 2 North & 2 North & 2 North & 2 North & 2 North \\
\hline Sample I.D. & $3 / 28 / 07$ 10:00 & $3 / 29 / 079: 15$ & $3 / 30 / 07$ 10:10 & $3 / 31 / 0714: 35$ & $3 / 24 / 0710: 45$ \\
\hline \multicolumn{6}{|l|}{ Fuel Properties - As Rece } \\
\hline$\%$ Total Moisture & 28.82 & 34.36 & 28.48 & 31.36 & 28.94 \\
\hline$\%$ Volatile Matter & 31.25 & 28.76 & 31.38 & 30.11 & 31.39 \\
\hline$\%$ Fixed Carbon & 35.42 & 32.69 & 35.40 & 33.89 & 35.06 \\
\hline$\%$ Ash & 4.51 & 4.19 & 4.74 & 4.65 & 4.61 \\
\hline HHV Btu/lb & 8445 & 7788 & 8503 & 8146 & 8471 \\
\hline$\%$ Moisture & 28.82 & 34.36 & 28.48 & 31.36 & 28.94 \\
\hline$\%$ Hydrogen & 3.44 & 3.12 & 3.41 & 3.24 & 3.35 \\
\hline$\%$ Carbon & 48.73 & 44.89 & 48.89 & 47.06 & 48.74 \\
\hline$\%$ Sulfur & 0.30 & 0.27 & 0.31 & 0.27 & 0.33 \\
\hline$\%$ Nitrogen & 0.69 & 0.64 & 0.69 & 0.70 & 0.72 \\
\hline$\%$ Oxygen (diff) & 13.50 & 12.53 & 13.48 & 12.72 & 13.30 \\
\hline$\%$ Ash & 4.51 & 4.19 & 4.74 & 4.65 & 4.61 \\
\hline$\%$ Total & 100.00 & 100.00 & 100.00 & 100.00 & 100.00 \\
\hline Ibs Ash/MM Btu & 5.34 & 5.38 & 5.58 & 5.70 & 5.45 \\
\hline Ibs SO2/MM Btu & 0.71 & 0.70 & 0.73 & 0.66 & 0.77 \\
\hline FCNM Ratio & 1.13 & 1.14 & 1.13 & 1.13 & 1.12 \\
\hline LHV $Q_{p}$ (net) Btu/lb & 7829 & 7145 & 7894 & 7523 & 7862 \\
\hline HHV (MAF basis) & 12667 & 12673 & 12734 & 12730 & 12748 \\
\hline Ibs Air(wet)/MMBtu & 748 & 745 & 744 & 747 & 744 \\
\hline Dulong HHV estimate Btu/I & 8211 & 7528 & 8221 & 7907 & 8177 \\
\hline Ibs H2O/MM Btu & 70.7 & 80.2 & 69.6 & 74.3 & 69.8 \\
\hline Ibs Hg/MM Btu & 7.59E-06 & 5.90E-06 & $6.73 \mathrm{E}-06$ & $6.74 \mathrm{E}-06$ & $6.71 E-06$ \\
\hline \multicolumn{6}{|l|}{ Fuel Properties - Dry Bas } \\
\hline$\%$ Volatile Matter & 43.90 & 43.82 & 43.87 & 43.86 & 44.17 \\
\hline \% Fixed Carbon & 49.76 & 49.80 & 49.50 & 49.37 & 49.34 \\
\hline$\%$ Ash & 6.34 & 6.38 & 6.63 & 6.77 & 6.49 \\
\hline HHV Btu/lb & 11864 & 11864 & 11890 & 11869 & 11921 \\
\hline$\%$ Hydrogen & 4.83 & 4.75 & 4.77 & 4.73 & 4.72 \\
\hline$\%$ Carbon & 68.47 & 68.39 & 68.36 & 68.56 & 68.59 \\
\hline$\%$ Sulfur & 0.42 & 0.42 & 0.43 & 0.39 & 0.46 \\
\hline$\%$ Nitrogen & 0.97 & 0.97 & 0.97 & 1.03 & 1.01 \\
\hline$\%$ Chlorine & 0.008 & 0.007 & 0.008 & 0.008 & 0.008 \\
\hline$\%$ Oxygen (diff) & 18.97 & 19.08 & 18.83 & 18.52 & 18.72 \\
\hline$\%$ Ash & 6.34 & 6.38 & 6.63 & 6.77 & 6.49 \\
\hline$\%$ Total & 100.00 & 100.00 & 100.00 & 100.00 & 100.00 \\
\hline Hg ( $\mu$ grams/gram dry coal) & 0.09 & 0.07 & 0.08 & 0.08 & 0.08 \\
\hline$\% \mathrm{~F}$ & 0.001 & 0.001 & 0.000 & 0.000 & 0.000 \\
\hline$\% \mathrm{Br}$ & 0.000 & 0.000 & 0.000 & 0.000 & 0.000 \\
\hline
\end{tabular}




\begin{tabular}{|c|c|c|c|c|c|c|c|}
\hline PPL \# & $7-2464-A$ & $7-2465-A$ & $7-2466-A$ & $7-2467-A$ & $7-2468-A$ & $7-2469-A$ & $7-2470-A$ \\
\hline $\begin{array}{l}\text { Sample Location } \\
\text { Sample ID }\end{array}$ & $\begin{array}{c}\text { North ESP } \\
\text { Hopper } 6 \\
\text { A } 13 \mathrm{~N}\end{array}$ & $\begin{array}{c}\text { North ESP } \\
\text { Hopper } 6 \\
\text { A23 N }\end{array}$ & $\begin{array}{c}\text { North ESP } \\
\text { Hopper } 6 \\
\text { A } 33 \mathrm{~N}\end{array}$ & $\begin{array}{c}\text { North ESP } \\
\text { Hopper } 6 \\
\text { A 43 N }\end{array}$ & $\begin{array}{c}\text { North ESP } \\
\text { Hopper } 6 \\
\text { A } 53 \mathrm{~N}\end{array}$ & $\begin{array}{c}\text { North ESP } \\
\text { Hopper } 6 \\
\text { A } 63 \mathrm{~N}\end{array}$ & $\begin{array}{c}\text { North ESP } \\
\text { Hopper } 6 \\
\text { B } 13 \mathrm{~S}\end{array}$ \\
\hline Date & $03 / 06 / 07$ & $03 / 06 / 07$ & $03 / 06 / 07$ & $03 / 06 / 07$ & $03 / 06 / 07$ & $03 / 06 / 07$ & $03 / 06 / 07$ \\
\hline Time & $15: 10$ & $15: 15$ & $15: 20$ & $15: 25$ & $15: 25$ & $15: 30$ & $15: 37$ \\
\hline$\% \mathrm{LOI}$ & & & & & & & 0.11 \\
\hline$\%$ Total C & 0.09 & 0.03 & 0.02 & 0.03 & 0.03 & 0.01 & 0.05 \\
\hline$\mu \mathrm{g} \mathrm{Hg} / \mathrm{gram}$ ash & 0.11 & 0.20 & 0.26 & 0.28 & 0.21 & 0.23 & 0.06 \\
\hline PPL \# & $7-2471-A$ & $7-2472-\mathrm{A}$ & $7-2473-A$ & $7-2475-A$ & $7-2476-A$ & $7-2477-A$ & $7-2478-A$ \\
\hline Sample Location & North ESP & North ESP & North ESP & North ESP & North ESP & North ESP & North ESP \\
\hline Sample ID & $\begin{array}{l}\text { Hopper } 6 \\
\text { B } 23 \mathrm{~S}\end{array}$ & $\begin{array}{l}\text { Hopper } 6 \\
\text { B } 33 \mathrm{~S}\end{array}$ & $\begin{array}{l}\text { Hopper } 6 \\
\text { B 43 S }\end{array}$ & $\begin{array}{l}\text { Hopper } 6 \\
\text { A } 13 \mathrm{~N}\end{array}$ & $\begin{array}{l}\text { Hopper } 6 \\
\text { A23 N }\end{array}$ & $\begin{array}{l}\text { Hopper } 6 \\
\text { A } 33 \mathrm{~N}\end{array}$ & $\begin{array}{c}\text { Hopper } 6 \\
\text { A 43 N }\end{array}$ \\
\hline Date & $03 / 06 / 07$ & $03 / 06 / 07$ & $03 / 06 / 07$ & $03 / 07 / 07$ & $03 / 07 / 07$ & $03 / 07 / 07$ & $03 / 07 / 07$ \\
\hline Time & $15: 35$ & $15: 33$ & $15: 32$ & $9: 30$ & $9: 30$ & $9: 30$ & $9: 30$ \\
\hline$\%$ LOI & 0.15 & & & 0.18 & 0.18 & & \\
\hline$\%$ Total C & 0.02 & 0.02 & 0.01 & 0.09 & 0.02 & 0.01 & 0.01 \\
\hline$\mu \mathrm{g} \mathrm{Hg} / \mathrm{gram}$ ash & 0.12 & 0.21 & 0.25 & 0.08 & 0.15 & 0.21 & 0.23 \\
\hline PPL\# & $7-2479-A$ & $7-2480-A$ & $7-2481-A$ & $7-2482-A$ & $7-2483-A$ & $7-2484-A$ & $7-2485-A$ \\
\hline Samole I cation & North ESP & North ESP & North ESP & North ESP & North ESP & North ESP & North ESP \\
\hline Sample ID & $\begin{array}{l}\text { Hopper } 6 \\
\text { A } 53 \mathrm{~N}\end{array}$ & $\begin{array}{c}\text { Hopper } 6 \\
\text { A } 63 \mathrm{~N}\end{array}$ & $\begin{array}{l}\text { Hopper } 6 \\
\text { B } 135\end{array}$ & $\begin{array}{l}\text { Hopper } 6 \\
\text { B } 23 \text { S }\end{array}$ & $\begin{array}{l}\text { Hopper } 6 \\
\text { B } 33 \text { S }\end{array}$ & $\begin{array}{l}\text { Hopper } 6 \\
\text { B } 43 \text { S }\end{array}$ & $\begin{array}{l}\text { Hopper } 6 \\
3 \mathrm{~A} 13 \mathrm{~W}\end{array}$ \\
\hline Date & $03 / 07 / 07$ & $03 / 07 / 07$ & $03 / 07 / 07$ & $03 / 07 / 07$ & $03 / 07 / 07$ & $03 / 07 / 07$ & $03 / 09 / 07$ \\
\hline Time & $9: 35$ & $9: 40$ & $9: 45$ & $9: 45$ & $9: 40$ & $9: 40$ & $8: 25$ \\
\hline$\%$ LOI & & & 0.12 & & & & \\
\hline$\%$ Total C & 0.02 & 0.01 & 0.06 & 0.02 & 0.04 & 0.01 & 0.09 \\
\hline$\mu \mathrm{g} \mathrm{Hg} / \mathrm{gram}$ ash & 0.22 & 0.15 & 0.06 & 0.06 & 0.11 & 0.19 & 0.09 \\
\hline PPL\# & $7-2486-A$ & $7-2487-A$ & $7-2488-A$ & $7-2489-A$ & $7-2490-A$ & $7-2491-A$ & $7-2492-A$ \\
\hline Sample Location & North ESP & North ESP & North ESP & North ESP & North ESP & North ESP & North ESP \\
\hline Sample ID & $\begin{array}{l}\text { Hopper } 6 \\
3 A 23\end{array}$ & $\begin{array}{c}\text { Hopper } 6 \\
3 A 33\end{array}$ & $\begin{array}{c}\text { Hopper } 6 \\
3 \mathrm{~A} 43\end{array}$ & $\begin{array}{c}\text { Hopper } 6 \\
3 A 53\end{array}$ & $\begin{array}{l}\text { Hopper } 6 \\
3 A 63 \mathrm{E}\end{array}$ & $\begin{array}{l}\text { Hopper } 6 \\
\text { 3B } 43\end{array}$ & $\begin{array}{c}\text { Hopper } 6 \\
\text { 3B } 33\end{array}$ \\
\hline Date & $03 / 09 / 07$ & $03 / 09 / 07$ & 03/09/07 & $03 / 09 / 07$ & $03 / 09 / 07$ & $03 / 09 / 07$ & $03 / 09 / 07$ \\
\hline Time & $8: 28$ & $8: 30$ & $8: 33$ & $8: 36$ & $8: 38$ & $8: 43$ & $8: 47$ \\
\hline$\%$ LOI & & & & & & & \\
\hline$\%$ Total C & 0.03 & 0.02 & 0.01 & 0.01 & 0.05 & 0.01 & 0.02 \\
\hline$\mu \mathrm{g} \mathrm{Hg} / \mathrm{gram}$ ash & 0.14 & 0.15 & 0.17 & 0.20 & 0.12 & 0.12 & 0.10 \\
\hline PPL\# & $7-2493-A$ & $7-2494-A$ & $7-2495-A$ & $7-2496-A$ & $7-2497-A$ & $7-2498-A$ & 7-2499-A \\
\hline Sample Location & North ESP & North ESP & North ESP & North ESP & North ESP & North ESP & North ESP \\
\hline cation & Hopper 6 & Hopper 6 & Hopper 6 & Hopper 6 & Hopper 6 & Hopper 6 & Hopper 6 \\
\hline Sample 1D & 3B 23 & 3B 13 & $\mathrm{~A} 13 \mathrm{~N}$ & $\mathrm{~A} 23 \mathrm{~N}$ & A33 N & $\mathrm{A} 43 \mathrm{~N}$ & A53 N \\
\hline Date & 03/09/07 & 03/09/07 & 03/19/07 & $03 / 19 / 07$ & $03 / 19 / 07$ & $03 / 19 / 07$ & $03 / 19 / 07$ \\
\hline Time & $8: 50$ & $8: 52$ & 15:11 & $15: 13$ & 15:17 & $15: 20$ & $15: 22$ \\
\hline$\%$ LOI & & 0.30 & & & & & \\
\hline$\%$ Total C & 0.03 & 0.26 & 0.13 & 0.09 & 0.07 & 0.08 & 0.07 \\
\hline$\mu \mathrm{g} \mathrm{Hg} / \mathrm{gram}$ ash & 0.09 & 0.05 & 0.34 & 0.84 & 0.86 & 1.00 & 0.83 \\
\hline
\end{tabular}




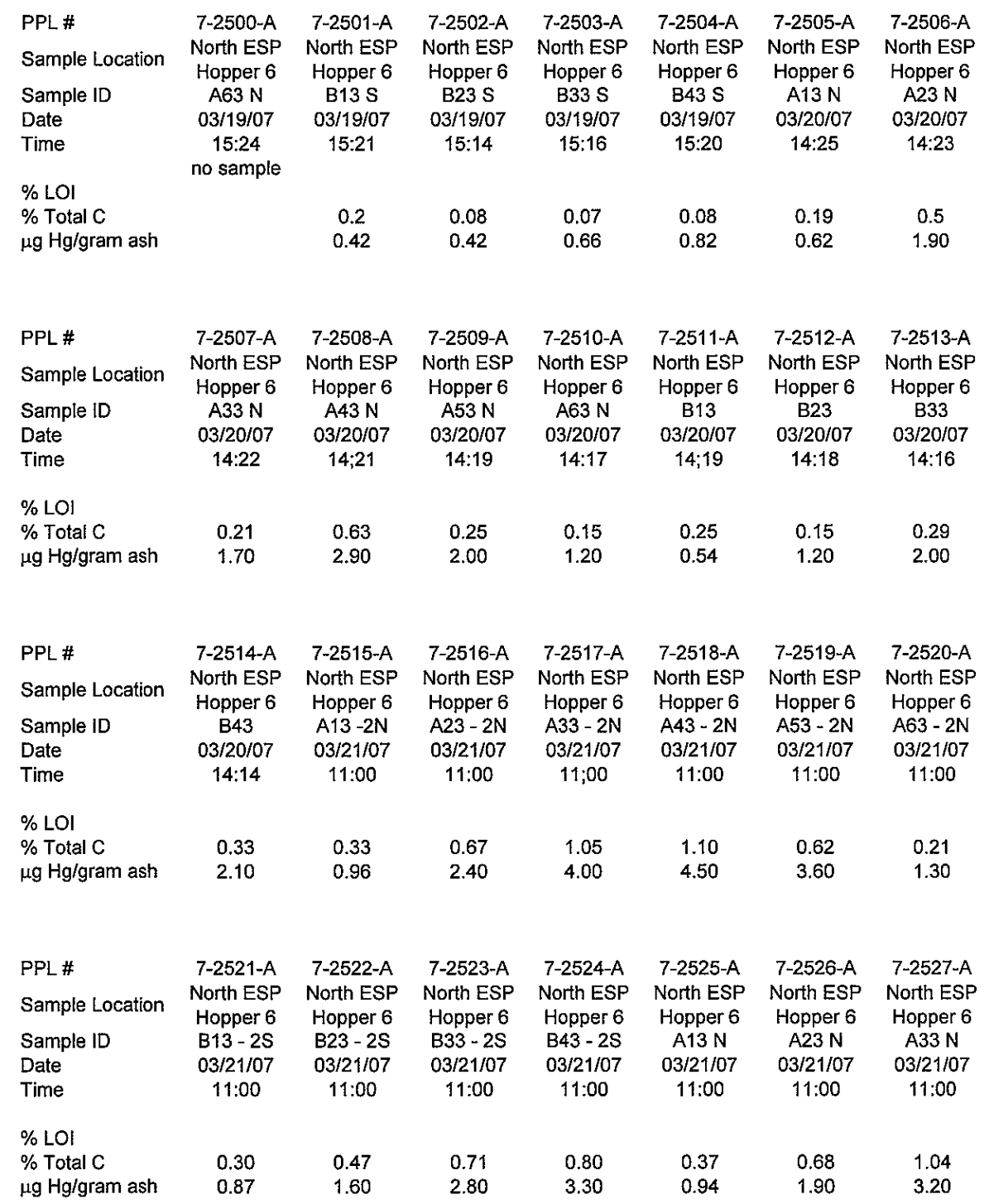

Alstom Power Inc. 


\begin{tabular}{|c|c|c|c|c|c|c|c|}
\hline PPL \# & 7-2528-A & $7-2529-A$ & $7-2530-A$ & $7-253 i-A$ & $7-2532-A$ & $7-2533-A$ & $7-2534-A$ \\
\hline Sample Location & North ESP & North ESP & North ESP & North ESP & North ESP & North ESP & North ESP \\
\hline Jample Lucalium & Hopper 6 & Hopper 6 & Норрег 6 & Hopper 6 & Hopper 6 & Hopper 6 & Hopper 6 \\
\hline Sample ID & $\mathrm{A} 43 \mathrm{~N}$ & A53 N & A63 N & $\mathrm{B} 13 \mathrm{~S}$ & B23 S & B33 S & B43 S \\
\hline Date & $03 / 21 / 07$ & $03 / 21 / 07$ & $03 / 21 / 07$ & $03 / 21 / 07$ & $03 / 21 / 07$ & $03 / 21 / 07$ & $03 / 21 / 07$ \\
\hline Time & 11:00 & 11:00 & $11: 00$ & 11:00 & 11:00 & $11: 00$ & 11:00 \\
\hline \multicolumn{8}{|l|}{$\%$ LOI } \\
\hline$\%$ Total C & 1.10 & 0.61 & 0.21 & 0.28 & 0.46 & 0.65 & 0.80 \\
\hline$\mu \mathrm{g} \mathrm{Hg} / \mathrm{gram}$ ash & 3.60 & 2.80 & 1.40 & 0.76 & 1.60 & 2.80 & 3.40 \\
\hline PPL \# & $7-2535-A$ & $7-2536-A$ & $7-2537-A$ & $7-2538-A$ & $7-2539-A$ & $7-2540-A$ & $7-2541-A$ \\
\hline Sample Location & North ESP & North ESP & North ESP & North ESP & North ESP & North ESP & North ESP \\
\hline Salnple Lucalion & Hopper 6 & Hopper 6 & Hopper 6 & Hopper 6 & Hopper 6 & Hopper 6 & Hopper 6 \\
\hline Sample ID & hopper B & hopper B & hopper B & hopper C & A13 & A13-2 & A23 \\
\hline Date & $03 / 22 / 07$ & $03 / 22 / 07$ & $03 / 22 / 07$ & $03 / 22 / 07$ & $03 / 23 / 07$ & $03 / 23 / 07$ & $03 / 23 / 07$ \\
\hline Time & $2: 42$ & $2: 45$ & base line & base line & $10: 45$ & $10: 45$ & $10: 43$ \\
\hline \multicolumn{8}{|l|}{$\%$ LOI } \\
\hline$\%$ Total C & 0.08 & 0.08 & 1.17 & 0.15 & 0.29 & 0.30 & 0.53 \\
\hline$\mu \mathrm{g} \mathrm{Hg} / \mathrm{gram}$ ash & 0.16 & 0.16 & 0.05 & 0.07 & 0.67 & 0.70 & 1.80 \\
\hline PPL \# & $7-2542-A$ & $7-2543-A$ & $7-2544-A$ & $7-2545-A$ & $7-2546-A$ & $7-2547-A$ & $7-2548-A$ \\
\hline Sample Location & North ESP & North ESP & North ESP & North ESP & North ESP & North ESP & North ESP \\
\hline Oalmple Lualion & Норрег 6 & Hopper 6 & Hopper 6 & Hopper 6 & Hopper 6 & Hopper 6 & Hopper 6 \\
\hline Sample ID & A23 - 2 & A33 & A33-2 & A43 & A43-2 & A53 & A53 - 2 \\
\hline Date & $03 / 23 / 07$ & $03 / 23 / 07$ & $03 / 23 / 07$ & $03 / 23 / 07$ & $03 / 23 / 07$ & $03 / 23 / 07$ & $03 / 23 / 07$ \\
\hline Time & $10: 44$ & $10: 47$ & $10: 47$ & $10: 50$ & $10 ; 50$ & $10: 57$ & $10: 57$ \\
\hline \multicolumn{8}{|l|}{$\%$ LOl } \\
\hline$\%$ Total C & 0.51 & 0.80 & 0.77 & 0.78 & 0.84 & 0.50 & 0.52 \\
\hline$\mu \mathrm{g} \mathrm{Hg} / \mathrm{gram}$ ash & 1.70 & 2.70 & 2.70 & 2.90 & 3.10 & 3.80 & 2.60 \\
\hline PPL \# & $7-2549-A$ & $7-2550-A$ & $7-2551-A$ & $7-2552-A$ & $7-2553-A$ & $7-2554-A$ & $7-2555-A$ \\
\hline Samole Location & North ESP & North ESP & North ESP & North ESP & North ESP & North ESP & North ESP \\
\hline Sample Lutation & Hopper 6 & Hopper 6 & Hopper 6 & Hopper 6 & Hopper 6 & Hopper 6 & Hopper 6 \\
\hline Sample ID & A63 & A63-2 & $\mathrm{B} 13$ & B13 - 2 & B23 & B23 - 2 & B33 \\
\hline Date & $03 / 23 / 07$ & $03 / 23 / 07$ & $03 / 23 / 07$ & $03 / 23 / 07$ & $03 / 23 / 07$ & $03 / 23 / 07$ & $03 / 23 / 07$ \\
\hline Time & 11:02 & 11:02 & $11: 20$ & $11: 20$ & $11: 15$ & 11:15 & $11: 09$ \\
\hline \multicolumn{8}{|l|}{$\%$ LOI } \\
\hline$\%$ Total C & 0.26 & 0.28 & 0.27 & 0.25 & 0.46 & 0.48 & 0.59 \\
\hline$\mu \mathrm{g} \mathrm{Hg} / \mathrm{gram}$ ash & 1.20 & 1.20 & 0.56 & 0.65 & 1.50 & 1.70 & 2.70 \\
\hline PPL \# & $7-2556-A$ & $7-2557-A$ & $7-2558-A$ & $7-2559-A$ & $7-2560-A$ & $7-2561-A$ & $7-2562-A$ \\
\hline Sample Location & North ESP & North ESP & North ESP & North ESP & North ESP & North ESP & North ESP \\
\hline Salmple Location & Hopper 6 & Hopper 6 & Hopper 6 & Hopper 6 & Hopper 6 & Hopper 6 & Hopper 6 \\
\hline Sample ID & B33 - 2 & B43 & B43 - 2 & hopper B & hopper B2 & A13 & A23 \\
\hline Date & $03 / 23 / 07$ & $03 / 23 / 07$ & $03 / 23 / 07$ & $03 / 23 / 07$ & $03 / 23 / 07$ & $03 / 28 / 07$ & $03 / 28 / 07$ \\
\hline Time & $11: 09$ & 11:04 & 11:04 & $11: 30$ & $11: 30$ & $11: 45$ & $11: 45$ \\
\hline \multicolumn{8}{|l|}{$\%$ LOI } \\
\hline$\%$ Total C & 0.69 & 0.65 & 0.67 & 0.09 & 0.11 & 0.33 & 0.48 \\
\hline$\mu \mathrm{g} \mathrm{Hg} / \mathrm{gram}$ ash & 2.90 & 3.00 & 3.30 & 0.09 & 0.07 & 0.89 & 1.60 \\
\hline
\end{tabular}

Alstom Power Inc. 


\begin{tabular}{|c|c|c|c|c|c|c|c|}
\hline PPL \# & $7-2563-A$ & $7-2564-A$ & $7-2565-A$ & $7-2566-A$ & $7-2567-A$ & $7-2568-A$ & $7-2569-A$ \\
\hline Sample Location & North ESP & North ESP & North ESP & North ESP & North ESP & North ESP & North ESP \\
\hline Sampie Location & Hopper 6 & Hopper 6 & Hopper 6 & Hopper 6 & Hopper 6 & Hopper 6 & Hopper 6 \\
\hline Sample ID & A33 & A43 & A53 & A63 & $\mathrm{B} 13$ & $\mathrm{~B} 23$ & B33 \\
\hline Date & $03 / 28 / 07$ & $03 / 28 / 07$ & $03 / 28 / 07$ & $03 / 28 / 07$ & $03 / 28 / 07$ & $03 / 28 / 07$ & $03 / 28 / 07$ \\
\hline Time & 11:45 & $11: 45$ & $11: 45$ & $11: 45$ & $11: 45$ & $11: 45$ & $11: 45$ \\
\hline \multicolumn{8}{|l|}{$\%$ LOI } \\
\hline$\%$ Total C & 0.84 & 0.51 & 0.42 & 0.23 & 0.35 & 0.34 & 0.48 \\
\hline$\mu \mathrm{g} \mathrm{Hg} / \mathrm{gram}$ ash & 2.60 & 2.50 & 2.50 & 1.30 & 0.54 & 1.50 & 2.40 \\
\hline PPL \# & $7-2570-A$ & $7-2571-A$ & $7-2572-A$ & $7-2573-A$ & $7-2574-A$ & $7-2575-A$ & $7-2576-A$ \\
\hline & North ESP & North ESP & North ESP & North ESP & North ESP & North ESP & North ESP \\
\hline Sample ID & $\begin{array}{l}\text { Hopper } 6 \\
\text { B43 }\end{array}$ & $\begin{array}{l}\text { Hopper } 6 \\
\text { hopper B }\end{array}$ & $\begin{array}{l}\text { Hopper } 6 \\
\text { hopper C }\end{array}$ & $\begin{array}{c}\text { Hopper } 6 \\
\text { A13 }\end{array}$ & $\begin{array}{c}\text { Hopper } 6 \\
\text { A23 }\end{array}$ & $\begin{array}{c}\text { Hopper } 6 \\
\text { A33 }\end{array}$ & $\begin{array}{c}\text { Hopper } 6 \\
\text { A43 }\end{array}$ \\
\hline Date & $03 / 28 / 07$ & $03 / 28 / 07$ & $03 / 28 / 07$ & $03 / 30 / 07$ & $03 / 30 / 07$ & $03 / 30 / 07$ & $03 / 30 / 07$ \\
\hline Time & $11: 45$ & $11: 47$ & $11 ; 47$ & $14: 15$ & $14: 15$ & $14: 15$ & $14: 15$ \\
\hline \multicolumn{8}{|l|}{$\%$ LOI } \\
\hline$\%$ Total C & 0.47 & 0.07 & 0.12 & 0.23 & 0.39 & 0.61 & 0.67 \\
\hline$\mu \mathrm{g} \mathrm{Hg} / \mathrm{gram}$ ash & 3.00 & 0.12 & 0.06 & 0.67 & 1.60 & 2.60 & 3.20 \\
\hline PPL \# & $7-2577-A$ & $7-2578-A$ & $7-2579-A$ & $7-2580-A$ & $7-2581-A$ & $7-2582-A$ & $7-2583-A$ \\
\hline Sample Location & North ESP & North ESP & North ESP & North ESP & North ESP & North ESP & North ESP \\
\hline Sample Location & Hopper 6 & Hopper 6 & Hopper 6 & Hopper 6 & Hopper 6 & Hopper 6 & Hopper 6 \\
\hline Sample ID & A53 & A63 & $\mathrm{B} 13$ & B23 & B33 & B43 & hopper B \\
\hline Date & $03 / 30 / 07$ & $03 / 30 / 07$ & $03 / 30 / 07$ & $03 / 30 / 07$ & $03 / 30 / 07$ & $03 / 30 / 07$ & $03 / 30 / 07$ \\
\hline Time & $14: 15$ & $14: 15$ & $14: 15$ & $14: 15$ & $14: 15$ & $14: 15$ & $14: 15$ \\
\hline \multicolumn{8}{|l|}{$\%$ LOI } \\
\hline$\%$ Total C & 0.49 & 0.27 & 0.17 & 0.38 & 0.53 & 0.58 & 0.12 \\
\hline$\mu \mathrm{g} \mathrm{Hg} / \mathrm{gram}$ ash & 2.80 & 1.70 & 0.45 & 1.70 & 2.80 & 3.50 & 0.11 \\
\hline PPL \# & $7-2584-A$ & $7-2586-A$ & $7-2587-A$ & $7-2588-A$ & $7-2589-A$ & $7-2590-A$ & \\
\hline Sample Location & $\begin{array}{c}\text { North ESP } \\
\text { Hopper } 6\end{array}$ & $\begin{array}{l}\text { Fly Ash - } \\
\text { Silo 3A }\end{array}$ & $\begin{array}{l}\text { Fly Ash - } \\
\text { Silo 3B-01 }\end{array}$ & $\begin{array}{l}\text { Fly Ash - } \\
\text { Silo 3B-02 }\end{array}$ & $\begin{array}{c}\text { Fly Ash - } \\
\text { Silo 3B } \\
(1 \text { of } 2)\end{array}$ & $\begin{array}{l}\text { Fly Ash - } \\
\text { Silo } 3 B \\
(2 \text { of } 2)\end{array}$ & \\
\hline Sample ID & hopper C & & & & & & \\
\hline Date & $03 / 30 / 07$ & $03 / 13 / 07$ & $03 / 23 / 07$ & $03 / 23 / 07$ & $03 / 30 / 07$ & $03 / 30 / 07$ & \\
\hline Time & $14: 15$ & & $17: 15$ & $17: 15$ & $16: 15$ & $16: 15$ & \\
\hline \multicolumn{8}{|l|}{$\%$ LOI } \\
\hline$\%$ Total C & 0.08 & 0.05 & 0.26 & 0.26 & 0.25 & 0.26 & \\
\hline$\mu \mathrm{g} \mathrm{Hg} / \mathrm{gram}$ ash & 0.09 & 0.28 & 1.30 & 1.30 & 1.40 & 1.40 & \\
\hline PPL \# & $7-2616-A$ & $7-2617-A$ & $7-2618-A$ & $7-2676-M$ & $7-2677-M$ & $\begin{array}{l}\text { 7-2678-M } \\
\text { FGD Filter }\end{array}$ & $7-2679-M$ \\
\hline Sample Location & $\begin{array}{l}\text { Fly Ash - } \\
\text { Silo B }\end{array}$ & $\begin{array}{c}\text { Fly Ash - } \\
\text { Silo B }\end{array}$ & $\begin{array}{l}\text { Fly Ash - } \\
\text { Silo B }\end{array}$ & & & $\begin{array}{l}\text { Cake - } \\
\text { Vacuum } \\
\text { Filter Belt }\end{array}$ & $\begin{array}{l}\text { FGD Filter } \\
\text { Cake - Pile }\end{array}$ \\
\hline Sample ID & hopper C & & & & & & \\
\hline Date & $03 / 28 / 07$ & $3 / 29 / 2007$ & $3 / 30 / 2007$ & & & $3 / 12 / 2007$ & $3 / 12 / 2007$ \\
\hline Time & 15:05 & $11: 35$ & 9:00 & & & $17: 00$ & 9:29 \\
\hline \multicolumn{8}{|l|}{$\%$ LOl } \\
\hline$\%$ Total C & 0.26 & 0.28 & 0.29 & & & & \\
\hline$\mu \mathrm{g} \mathrm{Hg} / \mathrm{gram}$ ash & 1.40 & 1.50 & 1.60 & & & 1.70 & 1.80 \\
\hline
\end{tabular}




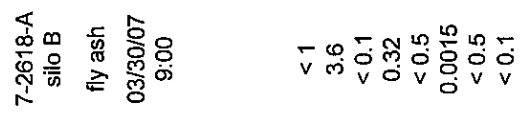

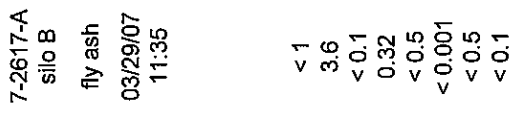

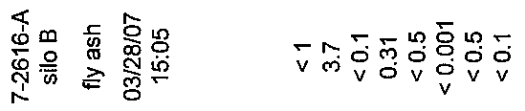

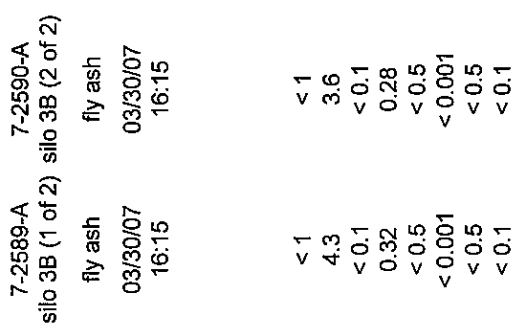

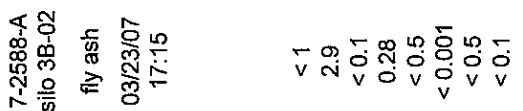

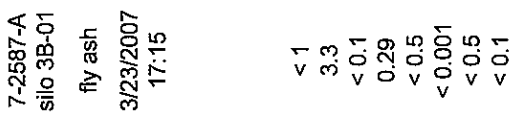

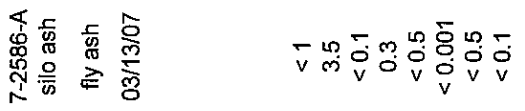

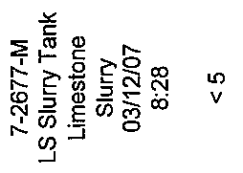

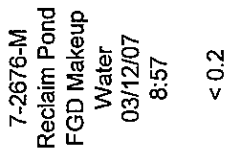

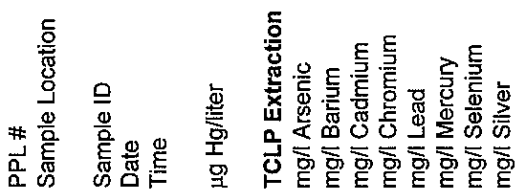


ALPHA ANALYTICAL LABORATORIES

Eight Walkup Drive

Westborough, Massachusetts 01581-1019

(508) 898-9220 www.alphalab.com

MA:M-MA086 NH:200301-A CT:PH-0574 ME:MA086 RI:65 NY:11148 NJ:MA935 Army: USACE

CERTIFICATE OF ANALYSIS

Client: Alstom Power

Laboratory Job Number: 50707573

Address: 2000 Day Hill Road

Windsor, CT 06095

Date Received: 24-MAY-2007

Attn: Mr. Kurt Johnson

Date Reported: 08-JUN-2007

Project Number:

Delivery Method: UPS

Site: USDOE MERCURY FIELD DEMO

ALPHA SAMPLE NUMBER

$$
\begin{aligned}
& \text { L0707573-01 } \\
& \text { L0707573-02 } \\
& \text { L0707573-03 } \\
& \text { L0707573-04 } \\
& \text { L0707573-05 } \\
& \text { L0707573-06 } \\
& \text { L0707573-07 } \\
& \text { L0707573-08 } \\
& \text { L0707573-09 } \\
& \text { L0707573-10 }
\end{aligned}
$$

CIIENT IDENTIFICATION

7-2676-M FGD MAKEUP WATE

7-2677-M FGD ISS SLURRY

7-2586-A FLYASH

7-2587-A ELYASH 3B1

7-2588-A FLYASH 3B2

7-2589-A FLYASH 3B1

7-2590-A FLYASH 3B2

7-2616-A FLYASH

7-2617-A FLYASH

7-2618-A ELYASH

\section{SAMPLE LOCATION}

LCRA-FAYETTE UNIT 3

LCRA-FAYETTE UNIT 3

LCRA-FAYETTE UNIT 3

LCRA-FAYETTE UNIT 3

LCRA-FAYE'TTE UNIT 3

ICRA-FAYETTE UNIT 3

ICRA-FAYETTE UNIT 3

LCRA-FAYETTE UNIT 3

ICRA-EAYETTE UNIT 3

LCRA-FAYETTE UNIT 3

I, the undersigned, attest under the pains and penalties of perjury that, based upon my personal inquiry of those responsible for obtaining the information, the material contained in this report is, to the best of my knowledge and belief, accurate and complete. This certificate of analys/s is not complete unless this page accompanies any and all pages of this report.

Authorized by

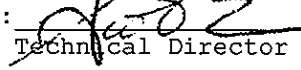

$06080715: 34 \quad$ Page 1 of 16 
ALPHA ANALYTICAL LABORATORIES

NARRATIVE REPORT

Laboratory Job Number: L0707573

The samples were received in accordance with the chain of custody and no significant deviations were encountered during preparation or analysis unless otherwise noted below.

Sample Receipt

The analysis of Mercury (Total and TCLP) was received with the method required holding time exceeded and was pexformed at the client's request.

The samples were received at the laboratory above the required temperature range. The samples were not on ice.

Total Mercury

L0707573-02 has an elevated detection limit due to the $25 \mathrm{x}$ prep dilution performed. This was done because of the sample matrix.

TCLP Metals

The MS $\frac{0}{6}$ recovery for Silver is below method acceptance criteria. A post analytical spike was performed with an acceptable recovery of $97 \%$.

$06080715: 34 \quad$ Fage 2 of 16 
ALPHA ANALYTICAI IABORATORIES

CERTIFICATE OF ANALYSIS

MA :M-MA086 NH:200301-A CT:PH-0574 ME:MA086 RI:65 NY:11148 NJ:MA935 Army:USACE

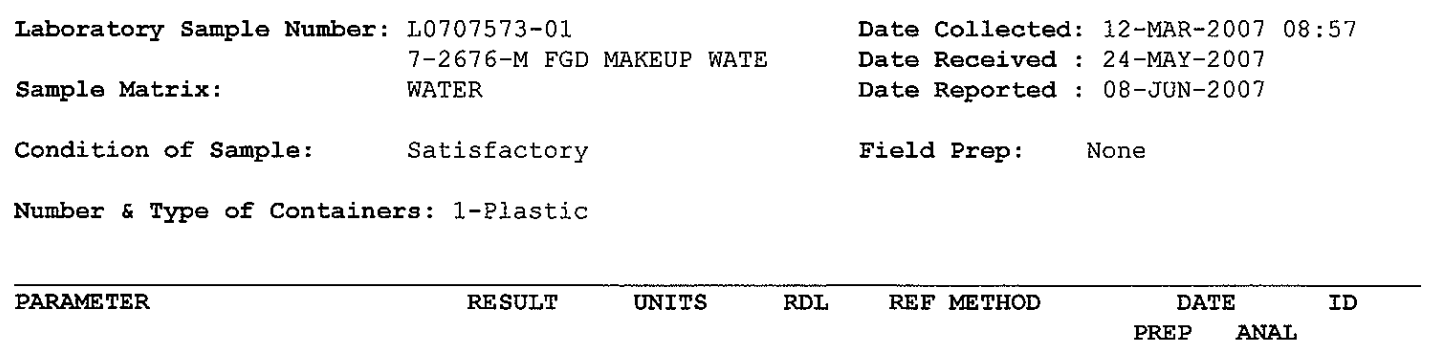

Total Metals

Mercury, Total

$\mathrm{mg} / 1$

$0.0002 \quad 3 \quad 245.1$

$0604 \quad 15: 050605 \quad 14: 14$ DM

Comments: Complete list of References and Glossary of Terms found in Addendum I

06080715:34 Page 3 of 16 
ALPHA ANALYTICAL IABORATORIES

CERTIFICATE OF ANALYSIS

MA :M-MA086 NH:20030I-A CT:PH-0574 ME:MA086 RI:65 NY:11148 NJ:MA935 Army: USACE

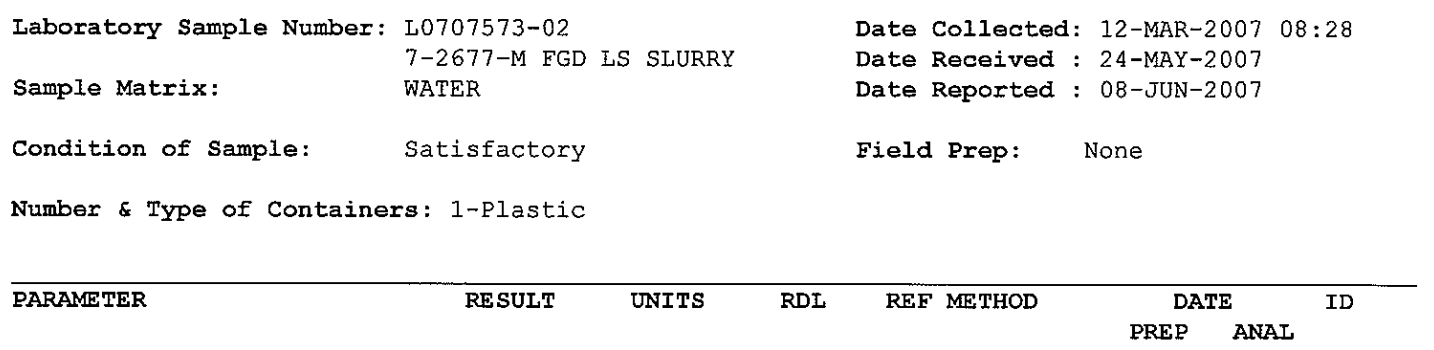

Total Metals

Mercury, Total

ND

$\mathrm{mg} / \mathrm{l}$

$0.0050 \quad 3 \quad 245.1$

$0604 \quad 15: 05060514: 20$ DM

Comments: Complete list of References and Glossary of Terms found in Addendum I

06080715:34 Page 4 of 16 
ALPHA ANAIYTICAI LLABORATORIES CERTIFICATE OF ANALYSIS

MA:M-MA086 NH: 200301-A CT:PH-0574 ME:MA086 RI: 65 NY:11148 NJ:MA935 Army:USACE

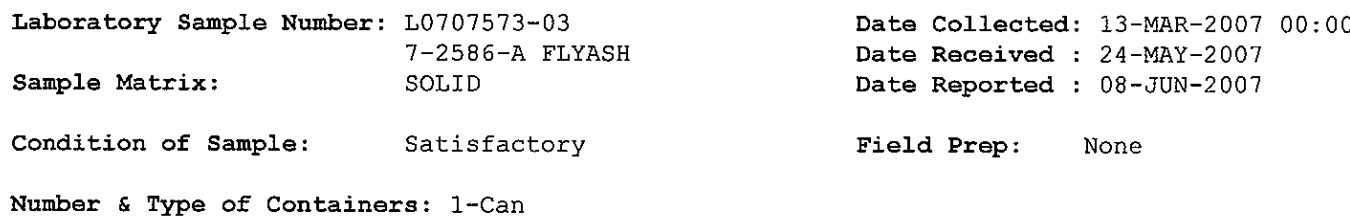

\begin{tabular}{llllll}
\hline PARAMETER & RESUIT & UNITS & RDL & REF METHOD & $\begin{array}{c}\text { DATE } \\
\text { PREP }\end{array}$ \\
\hline
\end{tabular}

TCLP Metals

TCIP Extraction

Arsenic, TCLP

Barium, TCLP

Cadmium, TCLP

Chromium, TCLP

Lead, TCLP

Mercury, TCLP

Selenium, TCEP

Silver, TCLP

$\begin{array}{lllll}\text { ND } & \mathrm{mg} / \mathrm{l} & 1.0 & 1 & 6010 \mathrm{~B} \\ 3.5 & \mathrm{mg} / \mathrm{l} & 0.50 & 1 & 6010 \mathrm{~B} \\ \mathrm{ND} & \mathrm{mg} / \mathrm{l} & 0.10 & 1 & 6010 \mathrm{~B} \\ 0.30 & \mathrm{mg} / \mathrm{l} & 0.20 & 1 & 6010 \mathrm{~B} \\ \mathrm{ND} & \mathrm{mg} / \mathrm{l} & 0.50 & 1 & 6010 \mathrm{~B} \\ \text { ND } & \mathrm{mg} / \mathrm{l} & 0.0010 & 1 & 7470 \mathrm{~B} \\ \text { ND } & \mathrm{mg} / \mathrm{l} & 0.50 & 1 & 6010 \mathrm{~B} \\ \text { ND } & \mathrm{mg} / \mathrm{l} & 0.10 & 1 & 6010 \mathrm{~B}\end{array}$

$060517: 30$

$0606 \quad 11: 20 \quad 0607 \quad 13: 30 \mathrm{MG}$ $0606 \quad 11: 20 \quad 0607 \quad 13: 30 \mathrm{MG}$ $0606 \quad 11: 20 \quad 0607 \quad 13: 30 \mathrm{MG}$ $060611: 200607 \quad 13: 30 \mathrm{MG}$ $0606 \quad 11: 20 \quad 0607 \quad 13: 30 \mathrm{MG}$ $060615: 300607 \quad 10: 05 \quad D$ $0606 \quad 11: 20 \quad 0607 \quad 13: 30 \mathrm{MG}$ $0606 \quad 11: 20 \quad 0607 \quad 13: 30 \quad M G$

Comments: Complete list of References and Glossary of Terms found in Addendum I

06080715:34 Page 5 of 16

Alstom Power Inc. 
AIPHA ANALYTICAL ILABORATORIES CERTIFICATE OF ANALYSIS

MA:M-MA086 NH:200301-A CT:PH-0574 ME:MA086 RI: 65 NY:11148 NJ:MA935 ArmY:USACE

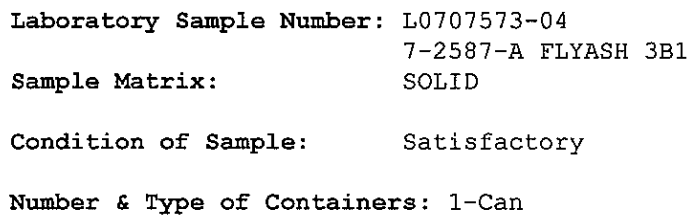

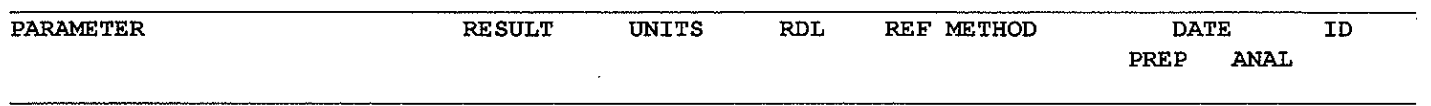

TCLP Metals

TCLP Extraction

Arsenic, TCLP

Baxium, TCLP

Cadnium, TCLP

Chromium, TCLP

Lead, TCLP

Mercury, TCLP

Selenium, TCLP

Si.lver, TCLP

$\begin{array}{lllll}\mathrm{ND} & \mathrm{mg} / 1 & 1.0 & 1 & 6010 \mathrm{~B} \\ 3.3 & \mathrm{mg} / 1 & 0.50 & 1 & 6010 \mathrm{~B} \\ \mathrm{ND} & \mathrm{mg} / 1 & 0.10 & 1 & 6010 \mathrm{~B} \\ 0.29 & \mathrm{mg} / 1 & 0.20 & 1 & 6010 \mathrm{~B} \\ \mathrm{ND} & \mathrm{mg} / 1 & 0.50 & 1 & 6010 \mathrm{~B} \\ \mathrm{ND} & \mathrm{mg} / \mathrm{I} & 0.0010 & 1 & 7470 \mathrm{~B} \\ \mathrm{ND} & \mathrm{mg} / 1 & 0.50 & 1 & 6010 \mathrm{~B} \\ \mathrm{ND} & \mathrm{mg} / \mathrm{l} & 0.10 & 1 & 6010 \mathrm{~B}\end{array}$

Date Collected: 23-MAR-2007 1.7:15

Date Received : 24-MAY-2007

Date Reported : 08-JUN-2007

Field Prep: None 
ALPHA ANALYTICAI ILABORATORIES

CERTIFICATE OE ANALYSIS

MA:M-MA086 NH:200301-A CT: BH-0574 ME:MA086 RI: 65 NY:11148 NJ:MA935 Army:USACE

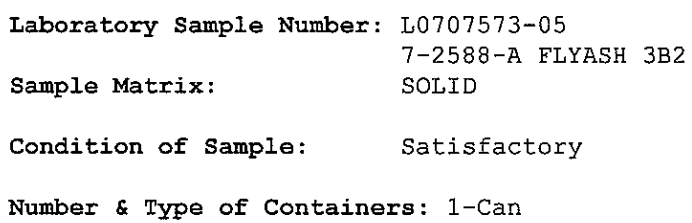

\begin{tabular}{|c|c|c|c|c|c|c|c|c|c|c|}
\hline \multirow[t]{2}{*}{ PARAMETER } & \multirow[t]{2}{*}{ RESULT } & \multirow[t]{2}{*}{ UNITS } & \multirow[t]{2}{*}{ RDI } & \multirow[t]{2}{*}{ REF } & \multirow[t]{2}{*}{ METHOD } & \multicolumn{4}{|c|}{ DATE } & \multirow[t]{2}{*}{ ID } \\
\hline & & & & & & & PREP & AN & TAL & \\
\hline TCLR Metals & & & & & & & & & & \\
\hline TCEP Extraction & & & & 2 & 1311 & .0605 & $17: 30$ & & & \\
\hline Arsenic, TCLP & ND & $\mathrm{mg} / \mathrm{l}$ & 1.0 & 1 & $6010 \mathrm{~B}$ & 0606 & $11: 20$ & 0607 & $13: 42$ & MG \\
\hline Barium, TCLP & 2.9 & $\mathrm{mg} / \mathrm{l}$ & 0.50 & 1 & $6010 \mathrm{~B}$ & 0606 & $21: 20$ & 0607 & $13: 42$ & MG \\
\hline Cadmium, TCLP & ND & $\mathrm{mg} / \mathrm{l}$ & 0.10 & 1 & $6010 \mathrm{~B}$ & 0606 & $11: 20$ & 0607 & $13: 42$ & MG \\
\hline Chromium, TCLP & 0.28 & $\mathrm{mg} / 1$ & 0.20 & 1 & $6010 \mathrm{~B}$ & 0606 & $11: 20$ & 0607 & $13: 42$ & MG \\
\hline Lead, TCLP & $\mathrm{ND}$ & $\mathrm{mg} / \mathrm{l}$ & 0.50 & 1 & $6010 B$ & 0606 & $11: 20$ & 0607 & $13: 42$ & MG \\
\hline Mercury, TCLP & $\mathrm{ND}$ & $\mathrm{mg} / 1$ & 0.0010 & 1 & $7470 \mathrm{~A}$ & 0606 & $15: 30$ & 0607 & $10: 08$ & $\mathrm{DM}$ \\
\hline Selenium, TCLP & ND & $\mathrm{mg} / \mathrm{l}$ & 0.50 & 2 & $6010 \mathrm{~B}$ & 0606 & $11: 20$ & 0607 & $13: 42$ & MG \\
\hline Silver, TCLP & ND & $\mathrm{mg} / \mathrm{l}$ & 0.10 & 1 & $6010 \mathrm{~B}$ & 0606 & $11: 20$ & 0607 & $13: 42$ & MG \\
\hline
\end{tabular}

Comments: Complete list of References and Glossary of Terms found in Addendum I

06080715:34 Page 7 of 16 
ALPHA ANALYTICAL LABORATORIES

CERTIFICATE OF ANALYSIS

MA:M-MA086 NH:200301-A CT:PH-0574 ME:MA086 RI:65 NY:11148 NJ:MA935 Army:USACE

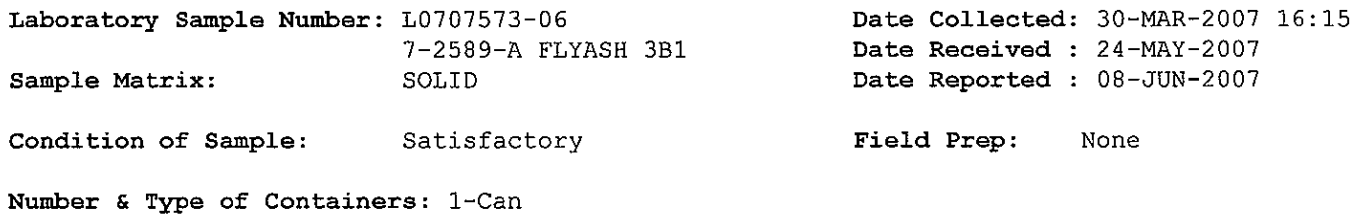

\begin{tabular}{llllll}
\hline PARAMETER & RESULT & UNITS & RDI & REF METHOD & $\begin{array}{c}\text { DATE } \\
\text { PREP ANAL }\end{array}$ \\
\hline
\end{tabular}

TCLP Metals

TCLP Extraction

Arsenic, TCLP

Barium, TCLP

Cadmium, TCLP

Chromium, TCEP

Lead, TCLP

Mercury, TCLP

Selenium, TCLP

Silver, TCLP

$\begin{array}{lllll}\text { ND } & \mathrm{mg} / \mathrm{l} & 1.0 & 1 & 6010 \mathrm{~B} \\ 4.3 & \mathrm{mg} / \mathrm{l} & 0.50 & 1 & 6010 \mathrm{~B} \\ \mathrm{ND} & \mathrm{mg} / \mathrm{l} & 0.10 & 1 & 6010 \mathrm{~B} \\ 0.32 & \mathrm{mg} / \mathrm{I} & 0.20 & 1 & 6010 \mathrm{~B} \\ \mathrm{ND} & \mathrm{mg} / \mathrm{I} & 0.50 & 1 & 6010 \mathrm{~B} \\ \text { ND } & \mathrm{mg} / \mathrm{l} & 0.0010 & 1 & 7470 \mathrm{~A} \\ \text { ND } & \mathrm{mg} / \mathrm{l} & 0.50 & 1 & 6010 \mathrm{~B} \\ \text { ND } & \mathrm{mg} / \mathrm{l} & 0.10 & 1 & 6010 \mathrm{~B}\end{array}$

$0605 \quad 17: 30$

$0606 \quad 11: 20 \quad 0607 \quad 13: 44$ MG $0606 \quad 11: 20 \quad 0607 \quad 13: 49 \mathrm{MG}$ $0606 \quad 11: 20 \quad 0607 \quad 13: 44 \quad M G$ $0606 \quad 11: 200607 \quad 13: 44 \mathrm{MG}$ $0606 \quad 11: 20 \quad 0607 \quad 13: 44$ MG $0606 \quad 15: 30 \quad 0607 \quad 30: 14 \quad$ DM $0606 \quad 11: 200607 \quad 13: 44 \mathrm{MG}$ $0606 \quad 11: 200607 \quad 13: 44 \quad M G$

Comments: Complete list of References and Glossary of Terms found in Addendum I

06080715:34 Page 8 of 16 
ALPHA ANALYTICAL LABORATORIES CERTIFICATE OF ANALYSIS

MA:M-MA086 NH: 200301-A CT:PH-0574 ME:MA086 RI:65 NY:11148 NJ:MA935 Army:USACE

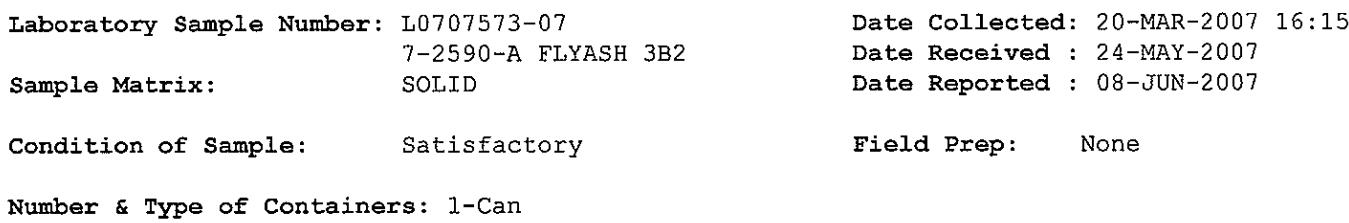

\begin{tabular}{llllll}
\hline PARAMETER & RESULT & UNITS & RDI. & REF METHOD & DATE \\
PREP ID & & & & &
\end{tabular}

TCLP Metals

TCYP Extraction

Arsenic, TCLP

Barium, TCLP

Cadmium, TCLP

Chromium, TCLP

Lead, TCLP

Mercuxy, TCLP

Selenium, TCLP

Silver, TCLP

$\begin{array}{lllll}\text { ND } & \mathrm{mg} / 1 & 1.0 & 1 & 6010 \mathrm{~B} \\ 3.6 & \mathrm{mg} / \mathrm{l} & 0.50 & 1 & 6010 \mathrm{~B} \\ \text { ND } & \mathrm{mg} / \mathrm{l} & 0.10 & 1 & 6010 \mathrm{~B} \\ 0.28 & \mathrm{mg} / \mathrm{l} & 0.20 & 1 & 6010 \mathrm{~B} \\ \mathrm{ND} & \mathrm{mg} / \mathrm{l} & 0.50 & 1 & 6010 \mathrm{~B} \\ \text { ND } & \mathrm{mg} / 1 & 0.0010 & 1 & 7470 \mathrm{~A} \\ \text { ND } & \mathrm{mg} / \mathrm{l} & 0.50 & 1 & 6010 \mathrm{~B} \\ \text { ND } & \mathrm{mg} / 1 & 0.10 & 1 & 6010 \mathrm{~B}\end{array}$

$060517: 30$

$0606 \quad 31: 200607 \quad 13: 47 \quad M G$ $0606 \quad 11: 200607 \quad 13: 47 \mathrm{MG}$ $060611: 200607 \quad 13: 47$ MG $0606 \quad 11: 20 \quad 0607 \quad 13: 47$ MG $060611: 200607 \quad 13: 47$ MG $0606 \quad 15: 30 \quad 0607 \quad 10: 16 \mathrm{DM}$ $0606 \quad 11: 200607 \quad 13: 47$ MG $0606 \quad 11: 20 \quad 0607 \quad 13: 47 \quad M G$ 
ALPHA ANALYTICAI LABORATORIES

CERTIFICATE OF ANALYSIS

MA :M-MA086 NH:200301-A CT:PH-0574 ME:MA086 RI:65 NY:11148 NJ:MA935 Army:USACE

\begin{tabular}{|c|c|c|c|}
\hline Laboratory Sample Number: & $\mathrm{L} 0707573-08$ & Date Collected & : $28-M A R-2007$ \\
\hline & $7-2616-A$ ELYASH & Date Received & $24-M A Y-2007$ \\
\hline Sample Matrix: & SOLID & Date Reported & : $08-J U N-2007$ \\
\hline Condition of Sample: & Satisfactory & Field Prep: & None \\
\hline
\end{tabular}

Number \& Type of Containers: 1-Can

\begin{tabular}{lllllll}
\hline PARAMETER & RESULT & UNITS & RDI & REF METHOD & DATE & ID \\
PREP ANAI & & & &
\end{tabular}

TCLP Metals

TCIP Extraction

$1311 \quad 060517: 30$

Arsenic, TCLP

Barium, TCLP

Cadmium, TCLP

Chromium, TCLP

Lead, TCLP

Mercury, TCLP

selenium, TCLP

Silver, TCLP

$\begin{array}{lllll}\text { ND } & \mathrm{mg} / \mathrm{l} & 1.0 & 1 & 6010 \mathrm{~B} \\ 3.7 & \mathrm{mg} / \mathrm{I} & 0.50 & 1 & 6010 \mathrm{~B} \\ \text { ND } & \mathrm{mg} / \mathrm{l} & 0.10 & 1 & 6010 \mathrm{~B} \\ 0.31 & \mathrm{mg} / \mathrm{I} & 0.20 & 1 & 6010 \mathrm{~B} \\ \mathrm{ND} & \mathrm{mg} / \mathrm{l} & 0.50 & 1 & 6010 \mathrm{~B} \\ \mathrm{ND} & \mathrm{mg} / \mathrm{I} & 0.0010 & 1 & 7470 \mathrm{~A} \\ \text { ND } & \mathrm{mg} / \mathrm{I} & 0.50 & 1 & 6010 \mathrm{~B} \\ \text { ND } & \mathrm{mg} / \mathrm{l} & 0.10 & 1 & 6010 \mathrm{~B}\end{array}$

$0606 \quad 11: 20 \quad 0607 \quad 13: 50 \quad M G$ $0606 \quad 11: 20 \quad 0607 \quad 13: 50 \mathrm{MG}$ $0606 \quad 11: 20 \quad 0607 \quad 13: 50$ MG $0606 \quad 11: 20 \quad 0607 \quad 13: 50 \mathrm{MG}$ $0606 \quad 11: 20 \quad 0607 \quad 13: 50 \mathrm{MG}$ $0606 \quad 15: 30 \quad 0607 \quad 10: 17 \quad \mathrm{DM}$ $0606 \quad 11: 20 \quad 0607 \quad$ 13:50 MG $0606 \quad 11: 200607 \quad 13: 50$ MG

Comments: Complete list of References and Glossary of Terms found in Addendum I

06080715:34 Page 10 of 16

Alstom Power Inc. 
ALPHA ANALYTICAL IAABORATORIES

CERTIFICATE OF ANALYSIS

MA :M-MA086 NH:200301-A CT:PH-0574 ME :MA086 RI:65 NY:11148 NJ:MA935 ArmY:USACE

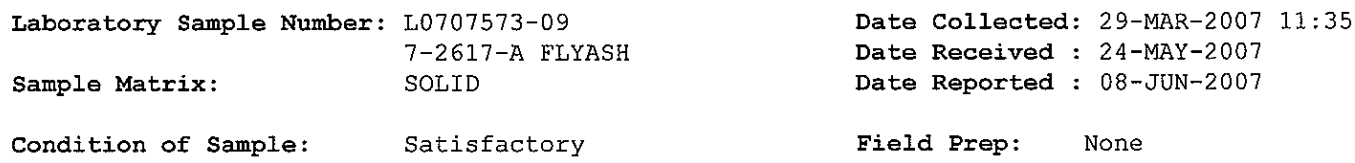

Number \& Type of Containers: 1-Can

\begin{tabular}{lllllll}
\hline PARAMETER & RESULT & UNITS & RDL & REF METHOD & $\begin{array}{c}\text { DATE } \\
\text { PREP }\end{array}$ & ID \\
\hline
\end{tabular}

TCLP Metals

TCFP Extraction

Arsenic, TCLP

Barium, TCLP

Cadmium, TCLP

Chromium, TCIP

Lead, TCLP

Mercury, TCLP

Selenium, TCLP

Silver, TCLP

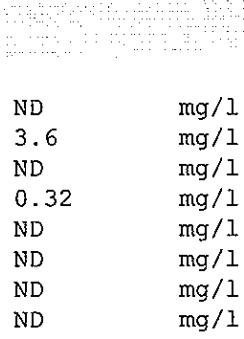

$\mathrm{mg} / \mathrm{l}$

$\mathrm{mg} / 1$

$\mathrm{mg} / 1$

$\mathrm{mg} / \mathrm{l}$

\section{0}

0.50

0.10

0.20

0.50

0.0010

0.50

0.10
1 1311 0605 17:30

160108

I $6010 \mathrm{~B}$

I $6010 \mathrm{~B}$

$16010 \mathrm{~B}$

$16010 \mathrm{~B}$

$17470 \mathrm{~A}$

$16010 \mathrm{~B}$

$16010 \mathrm{~B}$
$0606 \quad 11: 20 \quad 0607 \quad 13: 53 \quad \mathrm{MG}$ $0606 \quad 11: 20 \quad 0607 \quad 13: 53 \quad \mathrm{MG}$ $0606 \quad 11: 20 \quad 0607 \quad 13: 53 \quad M G$ $0606 \quad 11: 200607 \quad 13: 53$ MG $0606 \quad 11: 20 \quad 0607 \quad 13: 53 \mathrm{MG}$ $0606 \quad 15: 30 \quad 0607 \quad 10: 19$ $0606 \quad 11: 20 \quad 0607 \quad 13: 53$ MG $0606 \quad 11: 20 \quad 0607 \quad 13: 53$ MG

Comments: Complete list of References and Glossary of Terms found in Addendum I

06080715:34 Page 11 of 16

Alstom Power Inc. 
ALPHA ANALYTICAL LABORATORIES

CERTIFICATE OF ANALYSIS

MA:M-MA086 NH:200301-A CT:PH-0574 ME:MA086 RI:65 NY:11148 NJ:MA935 ArmY:USACE

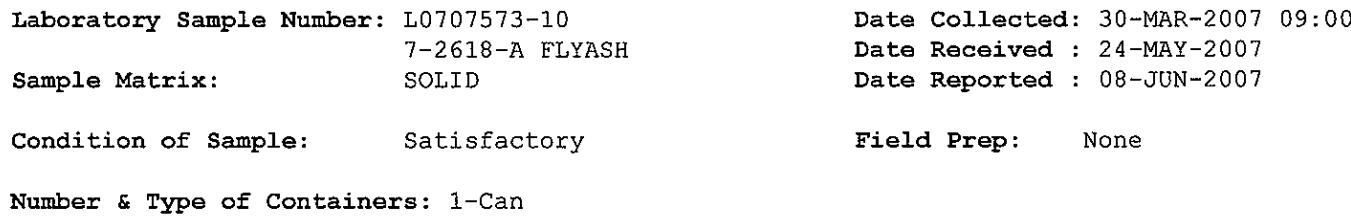

\begin{tabular}{lllllll}
\hline PARAMETER & RESULT & UNITS & RDI & REF METHOD & DATE & ID \\
PREP & & & & & ANAI &
\end{tabular}

TCLP Metals

TCLP Extraction

Arsenic, TCLP

Barium, TCJP

Cadmium, TCLP

Chromiun, TCLP

Lead, TCLP

Mercury, TCLP

Selenium, TCLP

Silver, TCLP

$\begin{array}{ll}\mathrm{m} & \mathrm{m} \\ \mathrm{n} & \mathrm{mg} / \mathrm{I} \\ \mathrm{ND} & \mathrm{mg} / \mathrm{I} \\ 3.6 & \mathrm{mg} / 1 \\ \mathrm{ND} & \mathrm{mg} / 1 \\ 0.32 & \mathrm{mg} / 1 \\ \mathrm{ND} & \mathrm{mg} / 1 \\ 0.0015 & \mathrm{mg} / 1 \\ \mathrm{ND} & \mathrm{mg} / 1 \\ \mathrm{ND} & \end{array}$

$\mathrm{mg} / \mathrm{l}$

$\mathrm{mg} / 1$

$\mathrm{mg} / 1$

$\mathrm{mg} / 1$

$\mathrm{mg} / 1$
1. $1311 \quad 060517 \div 30$

1. 0

0.50

0.10

0.20

0.50

0.0010

$16010 B$

$16010 \mathrm{~B}$

$16010 \mathrm{~B}$

$16010 \mathrm{~B}$

$16010 \mathrm{~B}$

$0.50 \quad 1 \quad 6010 \mathrm{~B}$

0.1016010
$0606 \quad 11: 20 \quad 0607 \quad 13: 56 \quad M G$ $0606 \quad 11: 20 \quad 0607 \quad 13: 56 \mathrm{MG}$ $0606 \quad 11: 200607 \quad 13: 56$ MG $0606 \quad 11: 20 \quad 0607 \quad 13: 56$ MG $0606 \quad 11: 200607 \quad 13: 56$ MG 0606 15:30 $0607 \quad$ 10:21 DM $0606 \quad 11: 200607 \quad 13: 56 \mathrm{MG}$ $0606 \quad 12: 200607 \quad 13: 56$ MG

Comments: Complete list of Refexences and Glossary of Terms found in Addendum I

06080715:34 Page 12 of 16

Alstom Power Inc. 
ALPHA ANALYTICAI IAABORATORIES QUALITY ASSURANCE BATCH DUPLICATE ANALYSIS

Laboratory Job Number: L0707573

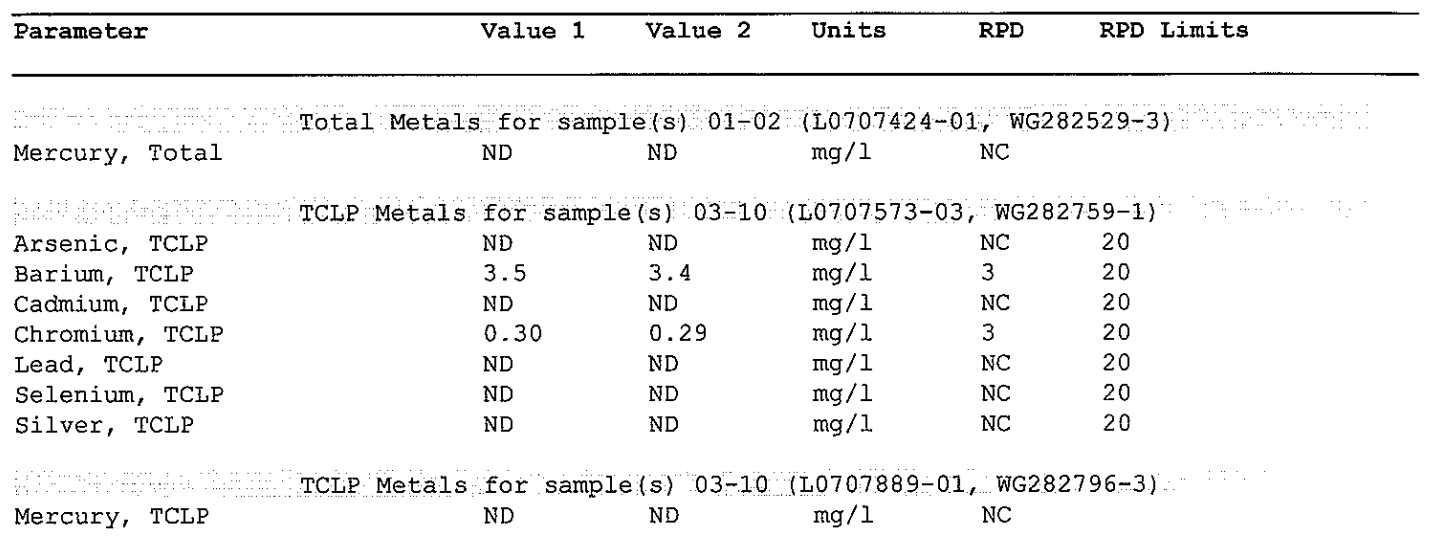




\section{QUALITY ASSURANCE BATCH SPIKE ANALYSES}

Iaboratory Job Number: L0707573

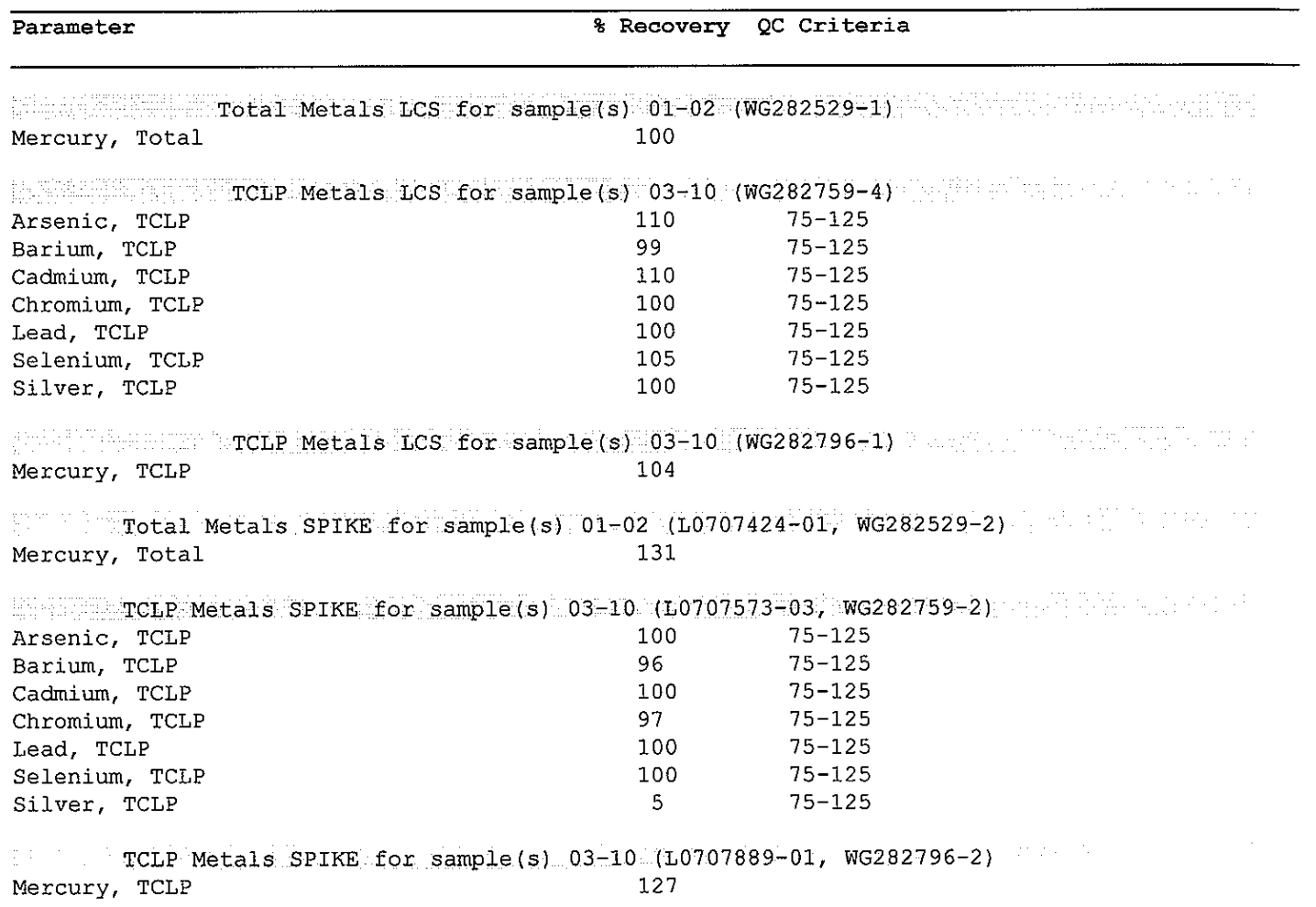

$06080715: 34 \quad$ Page 14 of 16

Alstom Power Inc. 
ALPHA ANALYTICAL ILABORATORIES QUALITY ASSURANCE BATCH BLANK ANALYSIS

Laboratory Job Number: L0707573

\begin{tabular}{lllllll}
\hline PARAMETER & RESULT & UNITS & RDL & REF METHOD & DATE & ID \\
& & & & PREP ANAL & &
\end{tabular}

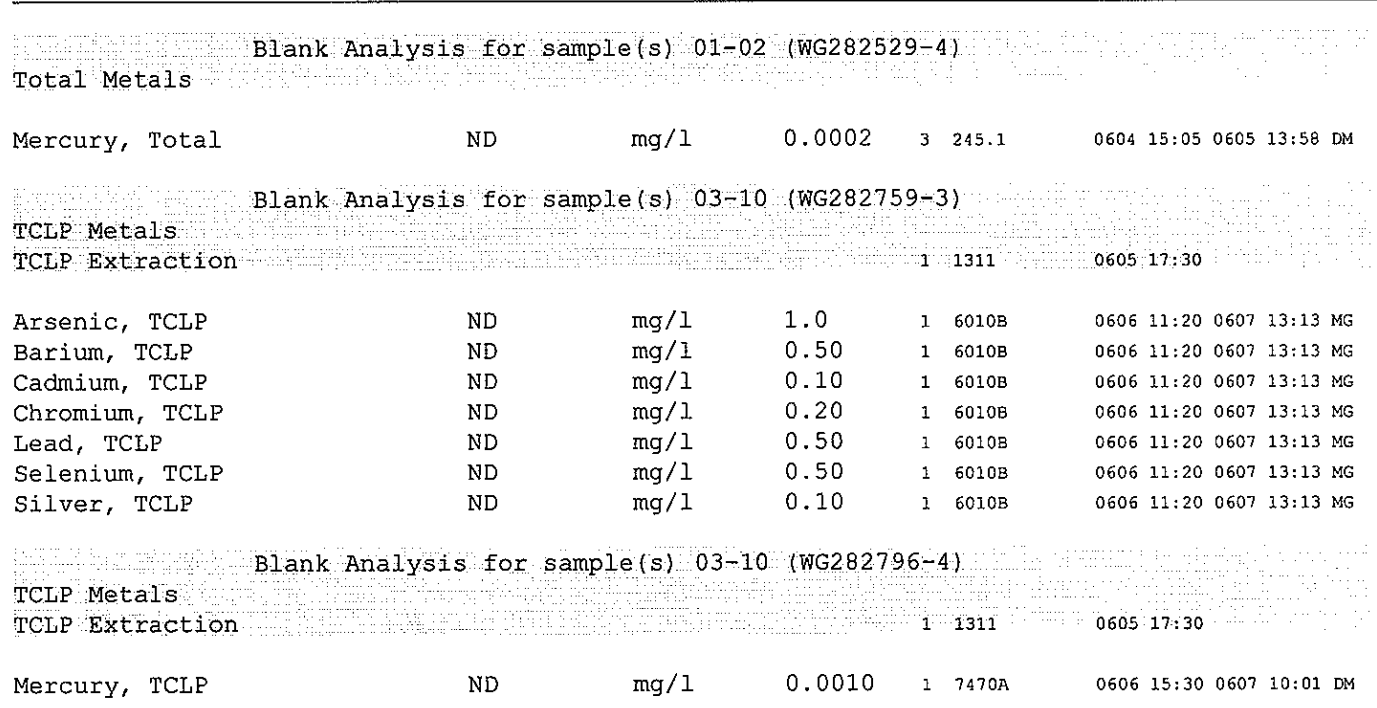

06080715:34 Page 15 of 16

Alstom Power Inc. 
ALPHA ANALYTICAL I.ABORATORIES ADDENDUM I

REFERENCES

1. Test Methods for Evaluating Solid Waste: Physical/Chemical Methods. EPA SW846. Third Edition. Updates I - IIIA, 1997.

3. Methods for the Determination of Metals in Environmental Samples, Supplement I. EPA/600/R-94/111. May 1994.

GLOSSARY OF TERMS AND SYMBOLS

REF Reference number in which test method may be found.

METHOD Method number by which analysis was performed.

ID Initials of the analyst.

ND Not detected in comparison to the reported detection limit.

NI Not Ignitable.

ug/cart Micrograms per Cartridge.

LIMITATION OF IIABILITIES

Alpha Analytical, Inc. performs services with reasonable care and diligence normal to the analytical testing laboratory industry. In the event of an error, the sole and exclusive responsibility of Alpha Analytical, Inc., shall be to re-perform the work at it's own expense. In no event shall Alpha Analytical, Inc. be held liable for any incidental consequential or special damages, including but not limited to, damages in any way connected with the use of, interpretation of, information or analysis provided by Alpha Analytical, Inc.

We strongly urge our clients to comply with ERA protocol regarding sample volume, preservation, cooling, containers, sampling procedures, holding times and splitting of samples in the field.

$06080715: 34 \quad$ Page 16 of 16 


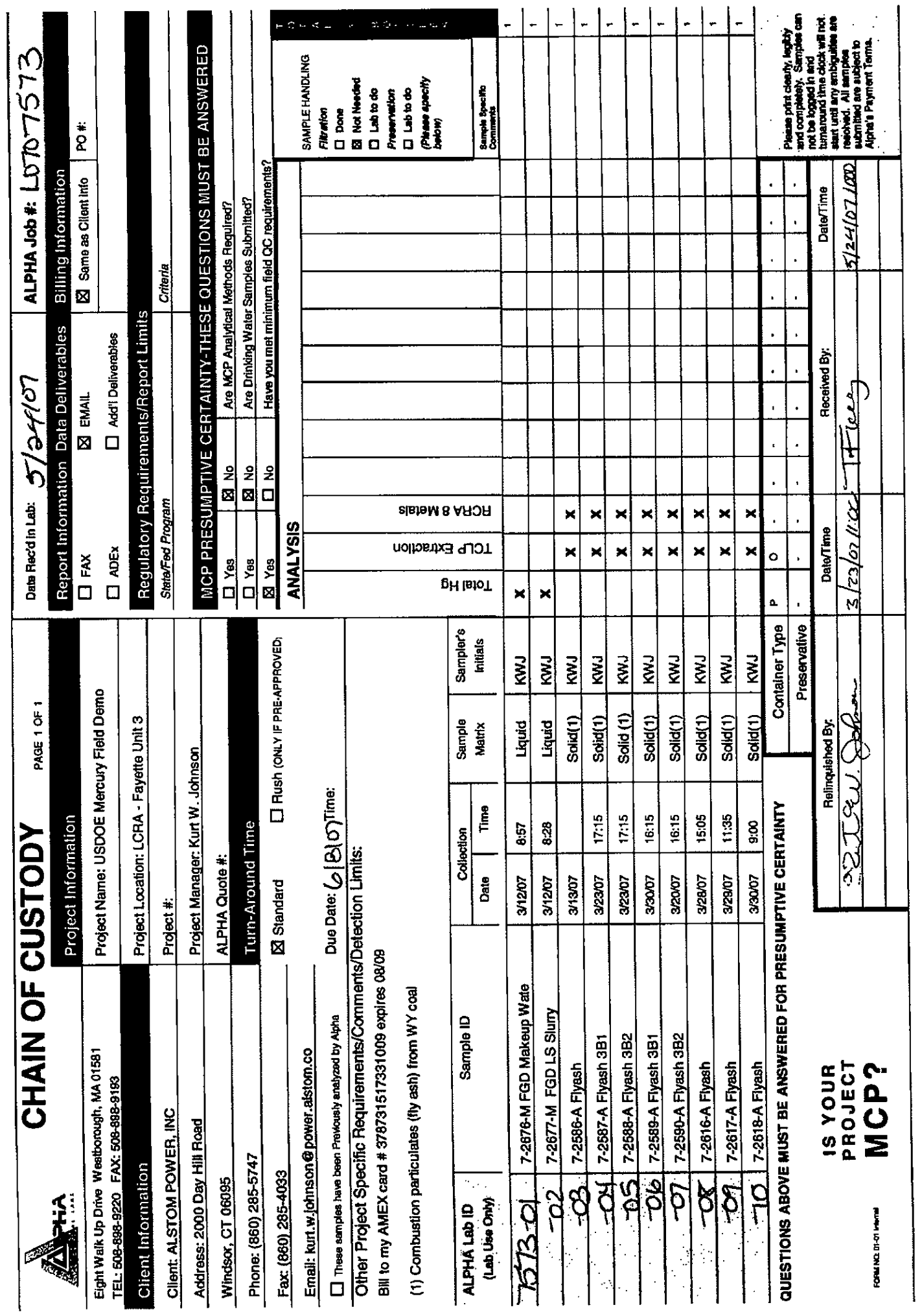

